September 2002 • NREL/SR-620-32819

\title{
Case Studies on the Effectiveness of State Financial Incentives for Renewable Energy
}

S. Gouchoe, V. Everette, and R. Haynes North Carolina State University Raleigh, North Carolina

\section{NPEI}

National Renewable Energy Laboratory

1617 Cole Boulevard

Golden, Colorado 80401-3393

NREL is a U.S. Department of Energy Laboratory

Operated by Midwest Research Institute $\bullet$ Battelle $\bullet$ Bechtel

Contract No. DE-AC36-99-G010337 


\section{Case Studies on the Effectiveness of State Financial Incentives for Renewable Energy}

S. Gouchoe, V. Everette, and R. Haynes North Carolina State University Raleigh, North Carolina

NREL Technical Monitor: Larry Goldstein

Prepared under Subcontract No. ADC-1-31425-01

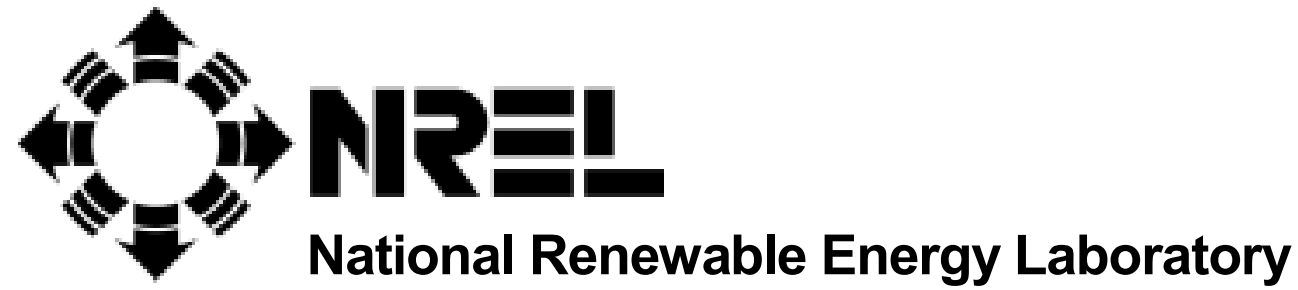

1617 Cole Boulevard

Golden, Colorado 80401-3393

NREL is a U.S. Department of Energy Laboratory

Operated by Midwest Research Institute $\bullet$ Battelle $\bullet$ Bechtel

Contract No. DE-AC36-99-G010337 


\section{NOTICE}

This report was prepared as an account of work sponsored by an agency of the United States government. Neither the United States government nor any agency thereof, nor any of their employees, makes any warranty, express or implied, or assumes any legal liability or responsibility for the accuracy, completeness, or usefulness of any information, apparatus, product, or process disclosed, or represents that its use would not infringe privately owned rights. Reference herein to any specific commercial product, process, or service by trade name, trademark, manufacturer, or otherwise does not necessarily constitute or imply its endorsement, recommendation, or favoring by the United States government or any agency thereof. The views and opinions of authors expressed herein do not necessarily state or reflect those of the United States government or any agency thereof.

Available electronically at http://www.osti.gov/bridge

Available for a processing fee to U.S. Department of Energy

and its contractors, in paper, from:

U.S. Department of Energy

Office of Scientific and Technical Information

P.O. Box 62

Oak Ridge, TN 37831-0062

phone: 865.576.8401

fax: 865.576.5728

email: reports@adonis.osti.gov

Available for sale to the public, in paper, from:

U.S. Department of Commerce

National Technical Information Service

5285 Port Royal Road

Springfield, VA 22161

phone: 800.553.6847

fax: 703.605.6900

email: orders@ntis.fedworld.gov

online ordering: http://www.ntis.gov/ordering.htm 


\section{TABLE OF CONTENTS}

List of Figures and Tables.................................................................................................................... ii

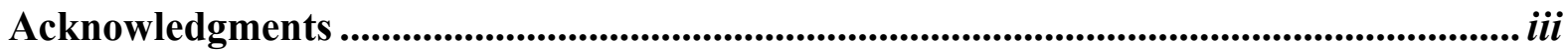

Executive Summary ...........................................................................................................

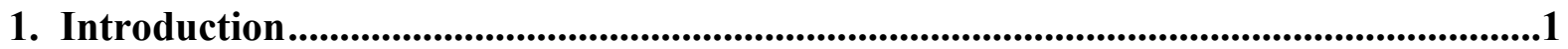

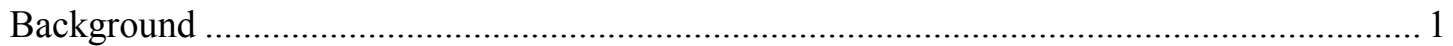

A Brief History of Financial Incentives and Renewables .................................................... 2

Recommended Elements of Financial Incentive Programs ....................................................... 3

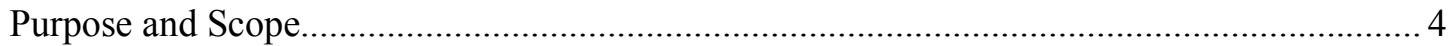

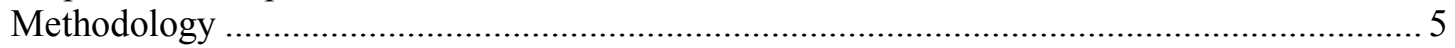

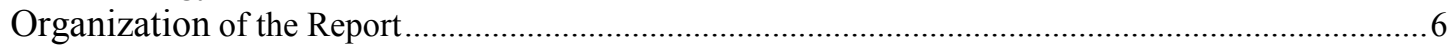

2. Overview of State Financial Incentives.....................................................................

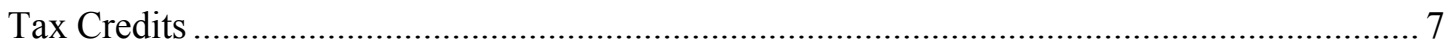

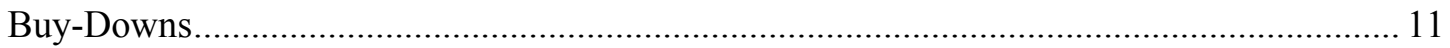

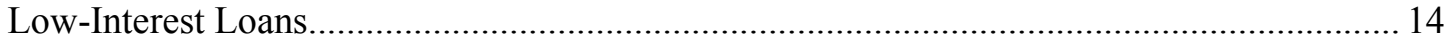

3. Observations and Lessons Learned..................................................................................17

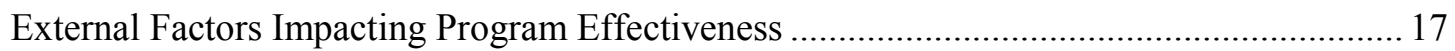

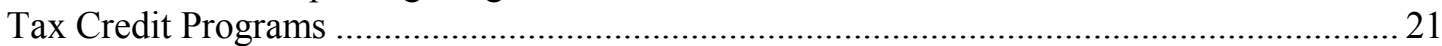

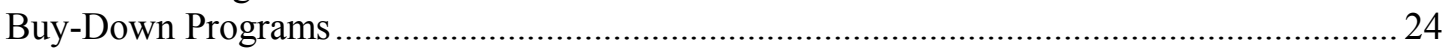

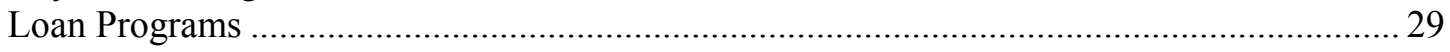

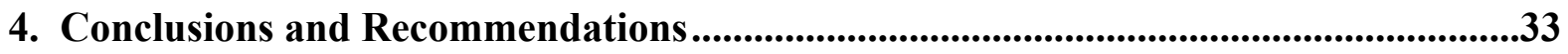

Appendix A: Tax-Credit Program Case Studies..............................................................36

New York - Solar Electric Generating Equipment Tax Credit................................................ 37

North Carolina - Renewable Energy Tax Credit ....................................................................... 43

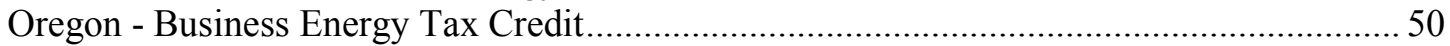

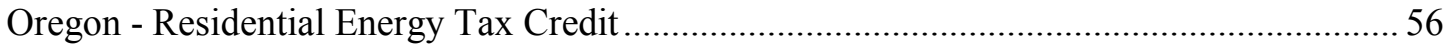

Appendix B: Buy-Down Program Case Studies .......................................................663

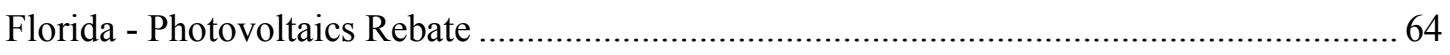

Illinois - Renewable Energy Resources Program ................................................................ 73

New York - Residential Photovoltaics Program ............................................................. 80

Appendix C: Loan-Program Case Studies ..........................................................................87

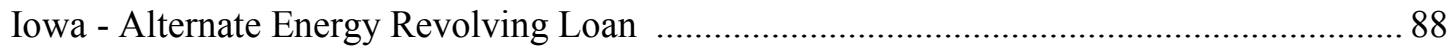

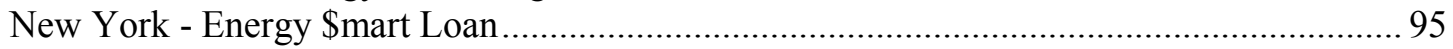

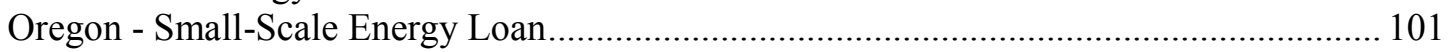

Appendix D: State Profiles ............................................................................................................107

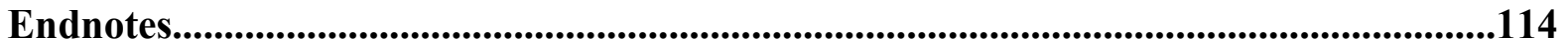




\section{LIST OF FIGURES AND TABLES}

Figure 1: States with Income Tax Credits for Renewable Energy Technologies ....................9

Figure 2: States with Buy-Down Programs for Renewable Energy Technologies.................13

Figure 3: States with Loan Programs for Renewable Energy Technologies .........................15

Table 1: State Financial Incentives for Renewable Energy ….........................................

Table 2: Overview of Case-Study Tax-Credit Programs ..................................................22

Table 3: Overview of Case-Study Buy-Down Programs.................................................25

Table 4: Overview of Case-Study Loan Programs ............................................................30

Table 5: New York Tax-Credit Program Results ............................................................39

Table 6: North Carolina Renewable Energy Tax-Credit Program Results for 2000 ............45

Table 7: Oregon Business Energy Tax-Credit Program Results .......................................53

Table 8: Oregon Residential Energy Tax-Credit Amounts by Technology ........................58

Table 9: Oregon Residential Tax-Credit Program Results ...............................................59

Table 10: Florida Photovoltaics Rebate Program Results ..................................................68

Table 11: Illinois Renewable Energy Resources Program Funding Categories and Limits...75

Table 12: Illinois Renewable Energy Resources Program Results......................................76

Table 13: New York Residential Photovoltaics Program Results ......................................83

Table 14: Iowa Alternate Energy Revolving-Loan Program Results ..................................91

Table 15: New York Energy \$mart Loan Program Results ...............................................98

Table 16: Oregon Small-Scale Energy Loan Program Results..........................................104

Table 17: Selected Florida Renewable Energy Policies .................................................... 108

Table 18: Selected Illinois Renewable Energy Policies ..................................................109

Table 19: Selected Iowa Renewable Energy Policies.......................................................110

Table 20: Selected New York Renewable Energy Policies ..............................................111

Table 21: Selected North Carolina Renewable Energy Policies.........................................112

Table 22: Selected Oregon Renewable Energy Policies.................................................113 


\section{ACKNOWLEDGMENTS}

This study was funded by the U.S. Department of Energy's Office of Energy Efficiency and Renewable Energy. The authors would like to thank Larry Goldstein of the National Renewable Energy Laboratory for his guidance and support throughout the project. Our deep appreciation goes to the many state incentive-program administrators, system installers, renewable energy advocates, state department of revenue officials, and other stakeholders who provided information and shared their experiences to help create this report. We received valuable input on the draft of this report from Ryan Wiser and Mark Bolinger of the Lawrence Berkeley National Laboratory, Matthew Brown of the National Conference of State Legislatures, Jane Weissman of the Interstate Renewable Energy Council, Frederick Beck of the Renewable Energy Policy Project, and James Caldwell of the American Wind Energy Association. Many thanks to these individuals for their suggestions. 


\section{EXECUTIVE SUMMARY}

The North Carolina Solar Center at NC State University, in collaboration with the National Renewable Energy Laboratory, examined 10 state financial-incentive programs in six states using a case-study approach in order to clarify the key factors - both internal and external to the program - that influence their effectiveness at stimulating deployment of renewable energy technologies. While existing information resources such as the National Database of State Incentives for Renewable Energy (DSIRE, www.dsireusa.org) have documented what incentive programs are available, the effectiveness of such programs is not well understood. Understanding the impact of current financial incentives on the deployment of renewables and the factors that influence their effectiveness is critical to a variety of stakeholders, particularly in states considering new incentives or interested in improving or discarding existing ones.

The types of incentives examined were those with the potential to increase the current smallscale renewables market significantly either through a reduction in the market price of the technology — tax credits and buy-downs - or by lowering the high initial capital outlay through low-interest loans. The scope of the study was limited to programs that support small-scale renewable energy technologies intended for on-site use in residential or small commercial applications. Given this scope, solar and small wind were the primary technologies supported by the incentives examined in this study. The following programs were examined:

\section{Tax-Credit Programs:}

New York Solar Electric-Generating Equipment Tax Credit

North Carolina Renewable Energy Tax Credit

Oregon Business Energy Tax Credit

Oregon Residential Energy Tax Credit

\section{Buy-Down Programs:}

Florida Photovoltaics Rebate

Illinois Renewable Energy Resources Program

New York Residential Photovoltaics Program

\section{Loan Programs:}

$\begin{array}{ll}\text { Iowa } & \text { Alternate Energy Revolving Loan } \\ \text { New York } & \text { Energy \$mart Loan } \\ \text { Oregon } & \text { Small-Scale Energy Loan }\end{array}$

Effectiveness can be measured in numerous ways: reduction in technology costs over time, number of renewable energy businesses established during the lifetime of an incentive program, capacity installed, amount of energy produced from projects installed under the program, number of participants, or measurement of performance relative to program goals. However, given the purpose and scope of this project, we use the term effectiveness in the context of the role the incentive plays in stimulating deployment and the degree to which the program reduces barriers to deployment. This study does not attempt a rigorous quantitative 
evaluation of state financial incentives. In many cases, detailed annual data on program use, funding distributed, or energy saved were not available. Because incentive programs take many shapes, and states vary widely in their socioeconomic, political, and climatic conditions, it was not possible to evaluate similarly structured programs in comparable environments to measure them against one another. Rather, the intention was to evaluate several different programs to identify common themes regarding program effectiveness that can be applied to other existing or proposed incentive programs.

Case studies on the experience and effectiveness of the selected programs were developed by conducting personal and telephone interviews with incentive-program administrators, department of revenue and other state officials, equipment distributors and installers, and representatives from advocacy groups and renewable energy associations. Program documents, including incentive applications and program-use data, and other relevant reports were also reviewed.

\section{Observations and Lessons Learned}

Several overarching themes emerged from interviews with stakeholders in the six case-study states regarding issues both internal and external to incentive programs that encourage and discourage the adoption of small-scale renewable energy technologies in their respective states. First, external factors will be discussed; illuminating the backdrop against which these incentive programs operate is important in understanding and assessing program performance. Following this discussion, the observations and lessons learned about the effectiveness of tax-credit, buy-down, and low-interest loan programs examined in this study will be presented, with an emphasis on the programmatic features and issues impacting their performance.

External Factors Impacting Program Effectiveness. Observations and lessons learned about these external factors that indirectly impact the effectiveness of incentive programs are as follows:

1. The case study states experienced varying levels of difficulty with respect to connecting renewable energy systems to the utility grid. In cases where the interconnection process is burdensome and costly, the effectiveness and value of incentive programs that encourage the installation of grid-connected technologies is severely compromised. Utility support and cooperation can enhance program effectiveness by ensuring a smooth interconnection process.

2. A weak infrastructure - including a shortage of qualified installers and inadequately trained building inspectors - can discourage consumers from purchasing renewable energy systems. Offering generous incentives to increase demand before an adequate distributor and installer infrastructure is in place can frustrate potential participants and delay or discourage installations.

3. Program participants tend to be strongly motivated by noneconomic factors. Concerns about environmental issues, a desire to reduce dependence on utilities, and more recently, power reliability and security threats are among the factors reported to be motivating consumers to purchase renewable energy systems. Many participants in the buy-down 
programs reportedly had a long-standing interest in renewables, and the incentive program inspired them to make the purchase.

4. A more comprehensive renewable energy education campaign may be necessary to increase deployment of renewables. An inadequate understanding of the types and benefits of renewables in general is still considered a major barrier to technology adoption. Given the attitudes that appear to play a role in the decision to invest in renewables, marketing campaigns designed to educate and mold attitudes of the general public accordingly are necessary to generate new interest in renewables.

5. A single financial incentive by itself is not likely to ensure significant market penetration of small-scale renewable energy technologies. Implementing a set of complementary incentives that may include net metering, low-interest loans, tax credits, property and sales tax exemptions, and/or buy-downs, can have a significant market impact relative to the historic small markets for PV and small wind.

Tax-Credit Programs. Historically, federal and state governments have used income-tax credits as one of the predominant tools to stimulate the deployment of renewable energy technologies. Income-tax credits are a direct reduction in a person's federal or state liability for some amount of system costs, thereby enhancing after-tax cash flows and promoting investment.

There are currently 15 states offering income-tax credits for renewable energy technologies, with nine states offering both personal and corporate tax credits. These programs are administered by state revenue departments or other state agencies. All but three of these 15 states consider both solar and wind technologies eligible for the incentive. Credits against income tax range from $10 \%$ to $35 \%$ of equipment and installation costs for both personal and corporate income-tax credits. Three states have performance-based credits. Maximum incentive amounts range from $\$ 1,000$ to $\$ 10,500$ for residential systems, and from $\$ 1,000$ to no limit for corporate tax credits. Most tax credits are designed to be claimed in the first year of production, allowing for any remaining credit to be carried over to the subsequent five (and, in a few cases, 10) years. The duration of most tax credits ranges from four to 13 years, while a few have no expiration date. Tax-credit programs vary widely with respect to system quality and performance provisions. While most at least call for compliance with government and industry installation and operating standards, some programs require detailed technical information, projected energy savings documentation, or post-installation certification.

The experience of tax-credit programs in three states - New York, North Carolina, and Oregon - offers the following lessons regarding program effectiveness:

1. The tax credit is not the primary motivating factor influencing purchasing decisions but often helps "seal the deal". In some cases, interested customers are unaware of the credit when they first contact a dealer, but the incentive plays a significant role in the final decision.

2. The choice of administrative agency may impact the effectiveness of the tax credit. Administering a tax credit through the state energy office rather than through the revenue department may allow better coordination with the design and administration of other 
energy programs and outreach activities, enable more detailed tracking of program performance data, and foster partnerships with the renewables industry in promoting the incentive. States should consider weighing these benefits against the costs of administrative activities.

3. The percentage of project costs eligible for a tax credit is considered to be adequate to stimulate interest in purchasing systems in these three states; but caps on eligible costs, low maximum amounts for higher cost technologies, and other credit limitations may reduce the effectiveness of the incentive.

4. Some mechanism for guaranteeing quality is necessary to ensure that states and project owners are investing in systems that perform as designed. Tax-credit programs employ various technology and installer requirements, but it is unclear how these provisions impact program effectiveness.

5. Developing mechanisms for non-taxed entities to take advantage of tax credits can stimulate deployment among these sectors. Allowing schools, nonprofits, and government agencies to partner with a business that can claim the credit and, in return, provide a direct payment to the nontaxed entity may increase the deployment of renewables as a result of the incentive.

Buy-Down Programs. Government-funded buy-down programs in the form of rebates or other cash incentives are used to encourage the installation of renewable energy technologies by reducing or "buying-down" initial equipment costs. The term "buy-down" is most often used for reductions in the bottom-line cost to purchasers, while "rebate" is used for a payment issued to the purchaser after the system has been installed. In this report, the term "buy-down" is used to refer to these types of incentives.

There are currently 11 state buy-down programs for renewable energy technologies, all of which have been initiated within the past several years. Nearly all of these programs are funded by public benefits funds and administered by the state's energy office, third-party fund administrator, or individual utilities. All of the buy-down programs fund PV installations, with several states targeting PV exclusively. About half of the programs also support wind technology development. A few programs include solar thermal systems or fuel cells as eligible technologies. Nearly all of the buy-down programs are available to residents and businesses. In addition to these sectors, some states extend eligibility to government entities, institutions, and nonprofits. Incentive levels range from $\$ 1.50$ per watt to $\$ 6$ per watt, with most states setting either a maximum expenditure of $20 \%$ to $60 \%$ of system cost or a maximum total dollar amount. In some states, incentive amount varies based on system size or technology. Technical and performance requirements vary widely among programs. In some cases, states initially imposed few requirements but later added quality assurance provisions after some systems were installed improperly. The use of preapproved contractors, preapproved equipment, and/or post-installation monitoring is mandated for buy-down recipients in some states. A couple of the buy-down programs initiated within the past year are employing performance-based incentives.

The experience of buy-down programs in three states - Florida, New York, and Illinoisoffers the following lessons regarding program effectiveness: 
1. Buy-downs can play a significant role in encouraging the deployment of photovoltaic systems. Individuals who have considered installing the technology for a number of years were inspired to make the purchase once the incentive became available.

2. Utility support and cooperation can greatly enhance the effectiveness of a buy-down for grid-connected technologies and are critical to ensure a quick and easy interconnection process. In cases where utilities imposed additional testing and administrative obstacles, installation of photovoltaic systems and buy-down participation were sluggish at best.

3. Offering generous buy-downs in the absence of an adequate number of qualified installers frustrates consumers and can discourage them from purchasing systems.

4. Offering buy-downs to support public-sector projects can help jump-start participation in and awareness of the incentive program.

5. Incentive amounts, which ranged from $\$ 3 / \mathrm{W}$ to $\$ 6 / \mathrm{W}$ in the case-study states, are generally considered adequate to stimulate interest in purchasing PV systems without devaluing the product. It is unclear what incentive level is optimal, but experience suggests that a high and sustainable incentive level may be required in the program's early years with levels declining as barriers are eliminated and the market matures.

6. Uncertain funding may disrupt the progress stimulated by the incentive program; once funding is depleted, potential participants may hold off on purchasing PV systems in anticipation of renewed funding.

7. A burdensome and detailed incentive application form can frustrate or deter potential program participants. Program administrators should make applications as quick and easy as possible without compromising the level of technical and financial details necessary to ensure project feasibility.

8. Some mechanism for guaranteeing quality is important to ensure that states and project owners are investing in systems that perform as designed. Buy-down programs employ various technology and installer requirements, but it is unclear how these provisions impact program effectiveness.

Loan Programs. Government-subsidized loans are used to encourage the installation of renewable energy technologies by helping customers overcome the financial barrier associated with high up-front equipment costs. Interested, but cash-challenged customers who could not otherwise purchase a system outright can buy one with the help of such loans, which typically provide lower interest rates, more favorable terms, and lower transaction costs relative to private lending arrangements.

There are at least 21 active loan programs in 18 states that provide low-cost financing for renewables. Some programs are funded by revolving loan funds, which were established with petroleum violation ("oil overcharge") escrow funds; while others are funded through annual appropriations, the sale of bonds, or air-quality noncompliance penalty fees. More recently established programs are funded by a public-benefits fund. Total funding for loan programs varies as well, with some programs operating with as little as $\$ 200,000$ per year while others lend up to $\$ 200$ million per year. While the majority of loan programs promote energy efficiency improvements in addition to renewable energy technologies, a handful of states 
have designed programs specifically for the promotion of renewables. Approximately half of the loan programs apply to homeowners and businesses, while others are available only to government and/or nonprofit and institutional entities. Interest rates vary from $1 \%$ to more than $6 \%$, with some programs setting rates on a case-by-case basis. Loan re-payment terms range from three to 20 years, with some based on individual project needs. Maximum loan amounts for residential applications are typically in the $\$ 10,000$ to $\$ 25,000$ range. Programs financing larger projects cap loan amounts at $\$ 100,000$ to $\$ 500,000$. Loan applications typically involve a technical description, which is evaluated by program administrators. A couple of the recently implemented loan programs require preapproved contractors and postinstallation inspections.

The experience of low-interest loan programs in three states-Iowa, New York, and Oregon — offers the following lessons regarding program effectiveness:

1. Low-interest loans can play an important supporting role in the deployment of renewable energy technologies but do not appear to be a significant driver in market development. Loans are most effective when coordinated with incentives that reduce up-front costs or with those that mandate the use of renewables.

2. Offering an interest rate significantly lower than the market rate and requiring minimal fees may be necessary to attract interest in loan programs.

3. Loan programs that partner with private lending institutions benefit by leveraging funds from private sources, but lenders are often reluctant to issue small loans, limiting the program's effectiveness in encouraging small-scale renewables deployment. Outreach and educational activities targeting the banking industry are critical to program success for these programs.

4. Educating and partnering with renewable energy businesses and advocacy organizations can leverage marketing activities and bolster interest in the program. As programs mature and evolve, it is necessary to supply equipment dealers and installers with updated promotional materials, including examples portraying the advantages of low-interest financing, and information about participating banks.

5. Some mechanism for guaranteeing quality is necessary to ensure that states and project owners are investing in systems that perform as designed. Loan programs employ various technology and installer requirements, but it is unclear how these provisions impact program effectiveness.

\section{Conclusions and Recommendations}

Developing sustainable markets for renewable energy technologies is a complex and challenging task. Advancement of these technologies faces informational, financial, and institutional barriers. As this study illustrates, states have adopted an assortment of approaches to reduce financial barriers to the deployment of renewables. Incentive programs examined in this study have had mixed success, with performance influenced by a variety of factors both internal and external to the program itself. Although the aggregate impacts of the incentives in the case-study states have been modest, it is important to note that some programs, particularly the relatively new buy-down programs, have played significant roles 
in increasing the number of grid-connected photovoltaics installed in their respective states. It has become clear that a smooth interconnection process is critical for success of these programs. Low-interest loans can play an important supporting role when coordinated with other significant incentives. Tax credits, if combined with outreach and education efforts and other complementary incentives (such as net metering), can also help drive the market for renewables. Clearly, states cannot expect any one of these incentives by itself to remove all the barriers to renewable energy technology development.

This study provides some potent examples of program design and implementation elements that have enhanced and limited program effectiveness. Although the unique socioeconomic, political, climatic, and infrastructure conditions at play within each state make a simple and uniform approach to incentive programs unworkable, states should consider the guiding principles below as they create new programs or modify existing ones. These principles reaffirm recommendations made by other reviews of financial incentives during the past three decades. Policy makers should consider setting the following conditions for incentive programs:

1. Work with other state programs and relevant stakeholder groups to educate the public about renewable energy technologies and to market the incentive program.

2. Offer a generous incentive level with stable, long-term funding that decreases over time as the market matures.

3. Design an easy and concise application process without compromising quality assurance.

4. Establish a consistent but cost-effective quality-assurance mechanism to protect consumers by guaranteeing adequate system performance.

5. Incorporate incentives into an overall infrastructure development strategy.

6. Develop a coordinated package of incentives.

7. Allow flexibility for program modifications.

8. Track the details of program use, costs, and energy savings/production to enable program evaluation and improvement.

Financial incentives are an important tool that can help individuals and businesses overcome the barrier of high initial equipment costs for these technologies. But, to be effective, these incentives should be considered as one component in a comprehensive approach to creating a sustainable market. Without other supportive policies, including education and outreach programs, a standardized and quick interconnection process for grid-connected systems, and complementary financial incentives (such as tax incentives, net metering, and low-interest financing), the effectiveness of financial-incentive programs in stimulating market development will be compromised. Addressing these needs and challenges requires partnerships and alliances among program administrators, advocates, equipment dealers and installers, lending institutions, utilities and public utilities commissions, and others who have authority over the financing or installation process. 


\section{INTRODUCTION}

\section{Background}

Since the early 1970s, a variety of issues relating to energy supply have disrupted the energy marketplace. The oil crises of the 1970s, the deregulation of electricity and gas markets, the ebb and flow of various conflicts in the Middle East, Y2K fears, air-quality concerns, the recognition of global warming, and California's recent energy supply woes are just some of the events and concerns that have affected both consumer perceptions and market prices. As these factors have contributed to increased energy costs and have created uncertainty in the energy market, consumers have actively sought more sustainable alternatives - often in the form of renewable energy technologies.

Renewable energy technologies — including solar, wind, biomass, geothermal, and hydropower - are in many ways attractive to policy makers who must address these market disruptions and the economic and social strife they can create. Renewable energy technologies are advantageous because they are immune to price shocks from fuel supply constraints and cartel pricing. Furthermore, renewable energy resources are much more environmentally benign than their conventional counterparts, such as coal, nuclear, and petroleum products. Renewable energy technologies can be used remotely at the point of need, or modularly upsized in a fashion that provides great flexibility to planners and short lead times to developers. While some of these technologies (particularly wind and solar) are subject to an intermittent supply, they can be matched in ways that make them useful in meeting peak demand, or they can be supplemented by other renewable technologies (such as biomass) that are "dispatchable" in nature.

Despite the many perks of renewable energy systems, there are several barriers to market development. The first and foremost of these barriers is cost. Most small-scale renewable energy technologies are substantially more expensive on a dollars-per-watt basis than conventional sources. Part of this cost inequity can be attributed to the array of generous subsidies for fossil and nuclear power. (These subsidies are so long-standing and well entrenched in the marketplace that they are hardly considered subsidies any longer.) This problem is exacerbated by the fact that current energy pricing does not reflect the harm to human health and the environment resulting from fossil-fuel use, which if accounted for, would make renewables more attractive.

There are also institutional issues to resolve. A path-dependent technology pattern has developed in the energy field that encourages the current centralized generation model of energy supply. When shifting away the capital investments in technology from centrally planned facilities toward distributed generation, renewable energy technologies and their prospective customers must fight against a tide of perceptions, practices, and market structures designed to facilitate the old central-station ways. In the end, consumers have a difficult time interconnecting renewable energy systems to the existing utility grid, as well as rendering their up-front capital investment into monthly payments that are less than their current power bills. 
Technology scale affects infrastructure in the marketplace as well. In order to convert to a distributed-energy system, technology standards are needed to ensure quality and consistency among a vastly increased number of generators. Similarly, the development and training of professionals to sell and install such technologies are necessary to facilitate delivery of a new product to market. This industry infrastructure is frequently lacking in states new to the business of "incentivising" renewable energy.

A fourth barrier to market development pertains to consumer awareness of renewable energy options. The disruptive factors described above evoke short-run consumer awareness for renewables, usually by forcing up prices of standard energy options. However, these disruptions are sporadic in nature and cannot create a sustained consumer awareness that would lead to the development of new markets for alternative energy solutions. When an oil crisis subsides, or when the power grid stabilizes, people quickly forget their past concerns about energy cost and stability. Accordingly, renewable energy technologies experience great difficulty in maintaining any short-run commercial success in mainstream energy markets.

To combat these barriers to new technology development, governments have invested millions of dollars in price supports - mostly in the form of consumer and corporate tax credits, consumer buy-downs, low-cost capital for consumers and businesses, as well as pricing regulations that favor renewable energy technologies. The overarching objective of these strategies has been to motivate consumers to use renewable energy technologies by "leveling the playing field" in an economic and institutional sense.

It should be noted, however, that these financial incentives are not the perfect solution for leveling the playing field. The fact that most renewable energy-incentive programs are subject to annual appropriation needs or sunset clauses - or are at risk from larger budgetary pressures in government - makes them uncertain in nature. Renewable energy businesses and consumers, and those who finance them, need long-term certainty of revenue streams to make projects work.

\section{A Brief History of Financial Incentives and Renewables}

Tax credits and other incentive programs for renewable energy are nothing new. In the 1970s and early 1980s - in the shadow of the first two national energy crises - a major push for energy efficiency and renewable energy came from the federal and state government agencies. Programs offering generous tax credits evolved in both levels of government: in many areas of the country, combined tax credits of 50 percent or more were available for solar energy technologies. Unfortunately, this was not the boon to market development originally envisioned by renewable energy advocates.

While the incentives were successful in stimulating consumer interest in solar energy systems, the market was not equipped to handle the mushrooming demand. Hundreds of thousands of solar hot-water systems were installed during this period, many of which are still in service today. The industry's staggering growth became a political force in many state legislatures in the Sun Belt. However, much of the equipment was designed and built by novice firms attracted by the large incentive payments, without expertise in technical issues regarding solar energy systems. Even technically sound systems were frequently installed by 
contractors who were unqualified to do so, leading to poor performance and frequent system failures. The industry began to suffer image problems with the media and consumers. In 1980, the industry went so far as to attempt to regulate itself with the creation of the Solar Ratings and Certification Corporation, a body intended to restore consumer confidence by overseeing quality issues in the manufacturing sector.

By the mid-1980s, the consumer public's memories of long waits at the gas station faded. In 1986, the federal tax credit expired, and states allowed their tax credits to follow suit. This actually compounded the incentive-driven market problem, as all of the providers and manufacturers who were drawn in by the tax-credit dollars subsequently left the solar business to pursue other opportunities. This left thousands of "orphan systems," as they have come to be called-systems that were installed but now had no one to service or supply parts for them. The few solar-thermal contractors who survived the ensuing market shakeout made much of their living into the 1990s by removing old systems and reselling component parts. Most solar-industry observers agree that the solar-thermal industry has never fully recovered from the boom-bust cycle.

In the wake of the 20-year anniversary of Earth Day in 1990 and the Gulf War shortly thereafter, environmental issues and renewable energy enjoyed renewed interest. Several states enacted new tax credits and began new loan and grant programs. In the late 1990s, states continued to take the lead in developing programs, policies, and incentives to promote the use of renewable energy, in part as a result of electric utility restructuring. The number of state incentives has grown steadily during the past few years-nearly 200 state financial incentives and as many regulatory policies are in effect across the United States. The experiences with federal and state tax credits of the '70s and '80s, as well as more recently implemented incentive programs both in the United States and abroad, offer many lessons for state policy makers as they continue to debate the most relevant and effective methods for reducing financial barriers to renewables.

\section{Recommended Elements of Financial-Incentive Programs}

A review of literature ${ }^{1}$ regarding experiences with renewable energy tax credits, buy-downs, and other incentives during the past three decades reveals a set of common principles for designing and implementing these programs. The recommendations below represent the elements considered to be critical to the success of financial incentive programs:

1. Funding Stability and Duration. Incentives should be available over multiyear terms and have stable funding. Many incentives offered during the 1980s were subject to annual appropriations, creating an uncertainty that prohibited sustained growth. This uncertainty can dissuade investments in larger projects in particular, due to longer planning and construction time frames.

2. Incentive Amount. First, the incentive level must be high enough - particularly in the first years of the program to stimulate interest and significant new investments - but not so high that it distorts the market sector it is intended to help. Second, the incentive amount should decline over time as the market develops. This acts to motivate potential customers to buy sooner when the incentive is higher and to help wean the industry and the marketplace off the incentive, easing the transition to a subsidy-free, but sustainable 
market. Finally, incentives should be limited to a certain level-per-watt capacity to prevent manufacturers and dealers from inflating prices.

3. Quality Assurance. Incentive programs must include provisions to ensure adequate system performance through minimum equipment standards, installer certification, and/or production-based incentives. Many solar systems installed under tax-credit programs in the 1970s and 1980s were plagued by quality problems due to shoddy equipment or improper installation.

4. Application Process. Incentives should be easy to apply for and include appropriate assistance from program administrators. Early adopters who experience a cumbersome and confusing application process accompanied by a long wait to receive the incentive payment (buy-downs) or approval (loans) are likely to spread the word to others, deterring potential customers from purchasing systems and/or using the program.

5. Consumer Education and Awareness. A sustained marketing campaign to educate the public about renewable energy technologies in general and about the availability of incentives in particular is critical to program success.

6. Institutional Barriers. Program success will be limited if institutional and structural issues are not addressed. These include working with utilities to develop smooth and standardized interconnection process, and educating the inspectors, realtors, insurers, bankers, utilities, and other stakeholders who may participate in or have authority over the process of deploying renewable energy technologies.

7. Complementary Financial Incentives. Any given incentive should be considered as an element of a package of policies designed to stimulate market development. Financial incentives that can complement or enhance tax credits and buy-downs include lowinterest loans, net metering, property tax exemptions, and sales-tax exemptions.

\section{Purpose and Scope}

While existing information resources such as the National Database of State Incentives for Renewable Energy (DSIRE, www.dsireusa.org) have documented available incentive programs, the effectiveness of such programs is not well understood. Understanding the impact of current financial incentives on the deployment of renewables - and the factors that influence their effectiveness - is critical to a variety of stakeholders, particularly for states considering new incentives or interested in improving or discarding existing ones. In addition to policy makers and other government officials, other stakeholders stand to benefit from this information as well, including public interest and environmental groups, individuals, and the renewable energy industry.

The purpose of the study is to assess the degree to which some of the current financialincentive programs are encouraging the installation of renewable energy systems and to clarify the key factors that make these programs effective or ineffective. Because incentive programs take many shapes (and states vary widely in their socioeconomic, political, and climatic conditions), it is not possible to evaluate similarly structured programs in comparable environments to measure them against one another. Rather, the intention is to 
evaluate several different programs to identify common themes regarding program effectiveness that can be applied to other existing or proposed incentive programs.

This study focuses on incentives that target small-scale renewable energy technologies intended for on-site use in residential or small commercial applications. Solar and small wind were naturally the primary relevant technologies given this scope. For incentives that were available to owners of large- and small-scale systems, the discussion centers primarily on the impact of the incentive on smaller applications.

The choice of incentive types was dictated by those with the potential to increase the current small-scale renewables market significantly either through a reduction in the market price of the technology (tax credits and buy-downs) or by lowering the high initial capital outlay through low-interest loans.

\section{Methodology}

The North Carolina Solar Center at NC State University examined 10 state financialincentive programs in six states to assess their effectiveness at stimulating the deployment of small-scale renewable energy technologies. The choice of state programs to include in the study was determined using the following criteria:

- the program is a tax-credit, buy-down, or low-interest loan for small-scale on-site renewable energy technologies, and at least one other type of financial incentive such as net metering or a property-tax exemption is available in the state;

- selected programs are from states that are a mix of those that have and have not undergone electric utility restructuring;

- selected programs are in states in different geographic regions of the United States; and

- the incentive program has been in operation for at least three years (when possible).

Based on these criteria, the following programs were examined:

\section{Tax-Credit Programs:}

$\begin{array}{ll}\text { New York } & \text { Solar-Electric Generating Equipment Tax Credit } \\ \text { North Carolina } & \text { Renewable Energy Tax Credit } \\ \text { Oregon } & \text { Business Energy Tax Credit } \\ \text { Oregon } & \text { Residential Energy Tax Credit }\end{array}$

\section{Buy-Down Programs:}

Florida

Photovoltaics Rebate

Illinois

Renewable Energy Resources Program

New York

Residential Photovoltaics Program

\section{Loan Programs:}

Iowa

New York

Alternate Energy Revolving Loan

Oregon 
Effectiveness can be measured in numerous ways: reduction in technology costs over time, number of renewable energy businesses established during the lifetime of an incentive program, capacity installed, amount of energy produced from projects installed under the program, number of participants, or measurement of performance relative to program goals. However, given the purpose and scope of this project - and the variety of factors influencing decisions toward the purchase of renewable energy systems - we use the term "effectiveness" in the context of the role the incentive plays in stimulating deployment, and the degree to which the program reduces barriers to deployment.

The authors gathered information for this study from (1) personal and telephone interviews with five to 10 individuals in each state, including program administrators, department of revenue and other state officials, equipment distributors and installers, advocacy groups, and renewable energy associations; and (2) a review of program documents, including incentive applications and program-use data, and other relevant reports.

We used a case-study approach to outline program design and implementation features of each incentive program, report participation results where available, and discuss programspecific factors that influence program effectiveness, as well as external issues that impact the deployment of renewables in general, and thus indirectly impact incentive programs. From these case studies, we identified some overall themes concerning the external influences at play in the six case-study states and summarized observations and lessons learned about the experience and effectiveness of tax credits, buy-downs, and loans, respectively. Based on these findings, we drew conclusions and made recommendations for the design and implementation of state financial-incentive programs.

This study does not attempt a rigorous quantitative evaluation of state financial incentives. In many cases, detailed annual data on program use, funding distributed, or energy saved are not available.

\section{Organization of the Report}

Chapter 2 provides an overview of state financial-incentive programs, which includes a discussion of the advantages and disadvantages of tax-credit, buy-down, and loan programs, respectively. It also describes the characteristics of state incentive programs across the United States. Chapter 3 summarizes observations and lessons learned about program effectiveness and the factors that influence it. Finally, Chapter 4 presents conclusions and recommendations.

Case studies on each of the 10 incentive programs evaluated are included as appendices. Also included as an appendix is a profile on energy use, renewable resource availability, and renewable energy policies in each of the case-study states. 


\section{OVerview of State Financial Programs}

In recent years, states have provided various financial incentives to promote the use of renewable energy technologies. Such incentives include direct cash incentives such as grants, loans, rebates, and buy-downs; income-tax credits and deductions; sales-tax and property-tax exemptions; and industry recruitment incentives. These incentives serve different purposes and result in different levels of benefits for those who take advantage of them. Table 1 shows the state-by-state availability of financial incentives for renewable energy. The incentive types examined in this study - tax credits, buy-downs, and loans - are discussed in more detail below. For more information on other types of incentives, or on programs mentioned below but not included as case studies in this report, please refer to the Database of State Incentives for Renewable Energy at www.dsireusa.org.

\section{Tax Credits ${ }^{2}$}

Historically, federal and state governments have used income-tax credits as one of the predominant tools to stimulate the deployment of renewable energy technologies. Investment-tax credits are a direct reduction in a person's federal or state liability for some amount of system costs, thereby enhancing after-tax cash flows and promoting investment. These investment-tax credits (ITCs) are simple to administer and enforce compared with other financial incentives. ITCs have been used extensively by states and may be more politically viable than cash payments because they do not require an annual appropriation. If tax credits are successful in expanding markets, they can ultimately result in a net gain in public revenue.

However, designing and implementing a successful ITC program presents several challenges. First, tax-credit benefits cannot be captured by government agencies, nonprofits, and schools because these entities have no state tax liability. Making a comparable grant or other type of cash incentive available to these organizations would help ensure equity among sectors. Oregon offers a unique solution to this drawback by employing a "pass-through" option whereby nontaxed organizations can receive the net present value of a tax credit they transfer to a third party, such as their energy services company, equipment vendor, or other business.

Second, system owners or investors with limited state tax burdens may not be able to take full advantage of the ITC. Thus, a tax credit may have little value to low- and moderateincome residents and others who have a small state-tax liability. While nearly all state taxcredit programs allow the unused portion of the credit to be carried over for five or 10 years, spreading the credit over time reduces its benefit.

Third, ITCs reward the purchase and installation of technologies regardless of potential or actual energy production. Federal ITCs implemented in the 1970s and 1980s have been criticized for promoting the creation of facilities rather than encouraging power production, resulting in the installation of ineffectual wind turbines by tax-burdened companies. The solar industry faced similar problems at that time. Attaching performance requirements or linking the incentive to power production can mitigate this potential problem. 
Table 1: State Financial Incentives for Renewable Energy*

\begin{tabular}{|c|c|c|c|c|c|c|c|c|c|}
\hline State & $\begin{array}{l}\text { Personal } \\
\text { Tax } \\
\text { Incentive }\end{array}$ & $\begin{array}{c}\text { Corporate } \\
\text { Tax } \\
\text { Incentive }\end{array}$ & $\begin{array}{l}\text { Sales-Tax } \\
\text { Exempt. }\end{array}$ & $\begin{array}{c}\text { Property- } \\
\text { Tax } \\
\text { Exempt. }\end{array}$ & $\begin{array}{c}\text { Buy- } \\
\text { Downs }\end{array}$ & Grants & Loans & $\begin{array}{l}\text { Industry } \\
\text { Recruit. }\end{array}$ & $\begin{array}{c}\text { Production } \\
\text { Incentive }\end{array}$ \\
\hline \multicolumn{10}{|l|}{$\begin{array}{l}\text { Alabama } \\
\end{array}$} \\
\hline \multicolumn{10}{|l|}{ Alaska } \\
\hline \multirow{2}{*}{\multicolumn{10}{|c|}{$\begin{array}{l}\text { Arizona } \\
\text { Arkansas }\end{array}$}} \\
\hline & & & & & & & & & \\
\hline \multicolumn{10}{|l|}{\begin{tabular}{|l} 
California \\
\end{tabular}} \\
\hline \multirow{2}{*}{\multicolumn{10}{|c|}{\begin{tabular}{|l|} 
Colorado \\
Connecticut
\end{tabular}}} \\
\hline & & & & & & & & & \\
\hline \multicolumn{10}{|l|}{\begin{tabular}{|l|l|} 
Delaware \\
\end{tabular}} \\
\hline \multirow{2}{*}{\multicolumn{10}{|c|}{$\begin{array}{l}\text { Florida } \\
\text { Georgia }\end{array}$}} \\
\hline & & & & & & & & & \\
\hline \multicolumn{10}{|l|}{ Hawaii } \\
\hline \multirow{2}{*}{\multicolumn{10}{|c|}{ Idaho }} \\
\hline \multirow{2}{*}{\multicolumn{10}{|c|}{ Illinois }} \\
\hline & & & & & & & & & \\
\hline \multicolumn{10}{|l|}{ Iowa } \\
\hline \multirow{2}{*}{\multicolumn{10}{|c|}{$\begin{array}{l}\text { Kansas } \\
\text { Kentucky }\end{array}$}} \\
\hline & & & & & & & & & \\
\hline \multicolumn{10}{|l|}{$\frac{\text { Kentucky }}{\text { Louisiana }}$} \\
\hline \multicolumn{10}{|l|}{\begin{tabular}{|l|} 
Maine \\
\end{tabular}} \\
\hline \multirow{2}{*}{\multicolumn{10}{|c|}{$\begin{array}{l}\text { Maryland } \\
\text { Massachusetts }\end{array}$}} \\
\hline & & & & & & & & & \\
\hline \multirow{2}{*}{\multicolumn{10}{|c|}{ Michigan }} \\
\hline \multirow{2}{*}{\multicolumn{10}{|c|}{$\frac{\text { Minnesota }}{\text { Mississippi }}$}} \\
\hline & & & & & & & & & \\
\hline \multicolumn{10}{|l|}{ Missouri } \\
\hline Montana & & & & & & & & & \\
\hline Nebraska & & & & & & & & & \\
\hline Nevada & & & & & & & & & \\
\hline New Hampshir & & & & & & & & & \\
\hline New Jersey & & & & & & & & & \\
\hline New Mexico & & & & & & & & & \\
\hline New York & & & & & & & & & \\
\hline North Carolina & & & & & & & & & \\
\hline North Dakota & & & & & & & & & \\
\hline Ohio & & & & & & & & & \\
\hline Oklahoma & & & & & & & & & \\
\hline Oregon & & & & & & & & & \\
\hline Pennsylvania & & & & & & & & & \\
\hline Rhode Island & & & & & & & & & \\
\hline South Carolina & & & & & & & & & \\
\hline South Dakota & & & & & & & & & \\
\hline Tennessee & & & & & & & & & \\
\hline Texas & & & & & & & & & \\
\hline Utah & & & & & & & & & \\
\hline Vermont & & & & & & & & & \\
\hline Virginia & & & & & & & & & \\
\hline Washington & & & & & & & & & \\
\hline West Virginia & & & & & & & & & \\
\hline Wisconsin & & & & & & & & & \\
\hline Wyoming & & & & & & & & & \\
\hline TOTAL & 14 & 15 & 14 & 24 & 11 & 12 & 19 & 8 & 1 \\
\hline
\end{tabular}

* U.S. Department of Energy, Database of State Incentives for Renewable Energy; http://www.dsireusa.org. Table does not include alternative fuels incentives. Personal and corporate tax incentives include credits, deductions, and exemptions. 
A production tax credit (PTC) is an example of such a performance-based incentive that provides the investor or owner of an eligible renewable energy system with an annual tax credit based on the amount of electricity generated by the system. By linking the incentive to energy produced rather than capital invested, this type of incentive encourages and rewards projects based on performance. However, ITCs rather than PTCs may be more appropriate for on- and off-grid small-scale systems used for on-site power generation because the administrative complexity of annual production payments would likely be cost-prohibitive. Likewise, measuring the exact electric production of an off-grid system would be difficult.

Finally, two federal incentives - the production tax credit for wind and closed-loop biomass, and the $10 \%$ business investment tax credit for solar and geothermal property-are reduced if recipients receive any government grants, financing, or any other credits. Thus, for projects that are eligible for federal incentives, state tax credits could be "wasted" by displacing the federal incentives. ${ }^{3}$

There are currently 15 states offering income-tax credits for renewable energy technologies", with nine states ${ }^{\dagger}$ offering both personal and corporate tax credits. Figure 1 shows the states currently offering personal and corporate tax credits.

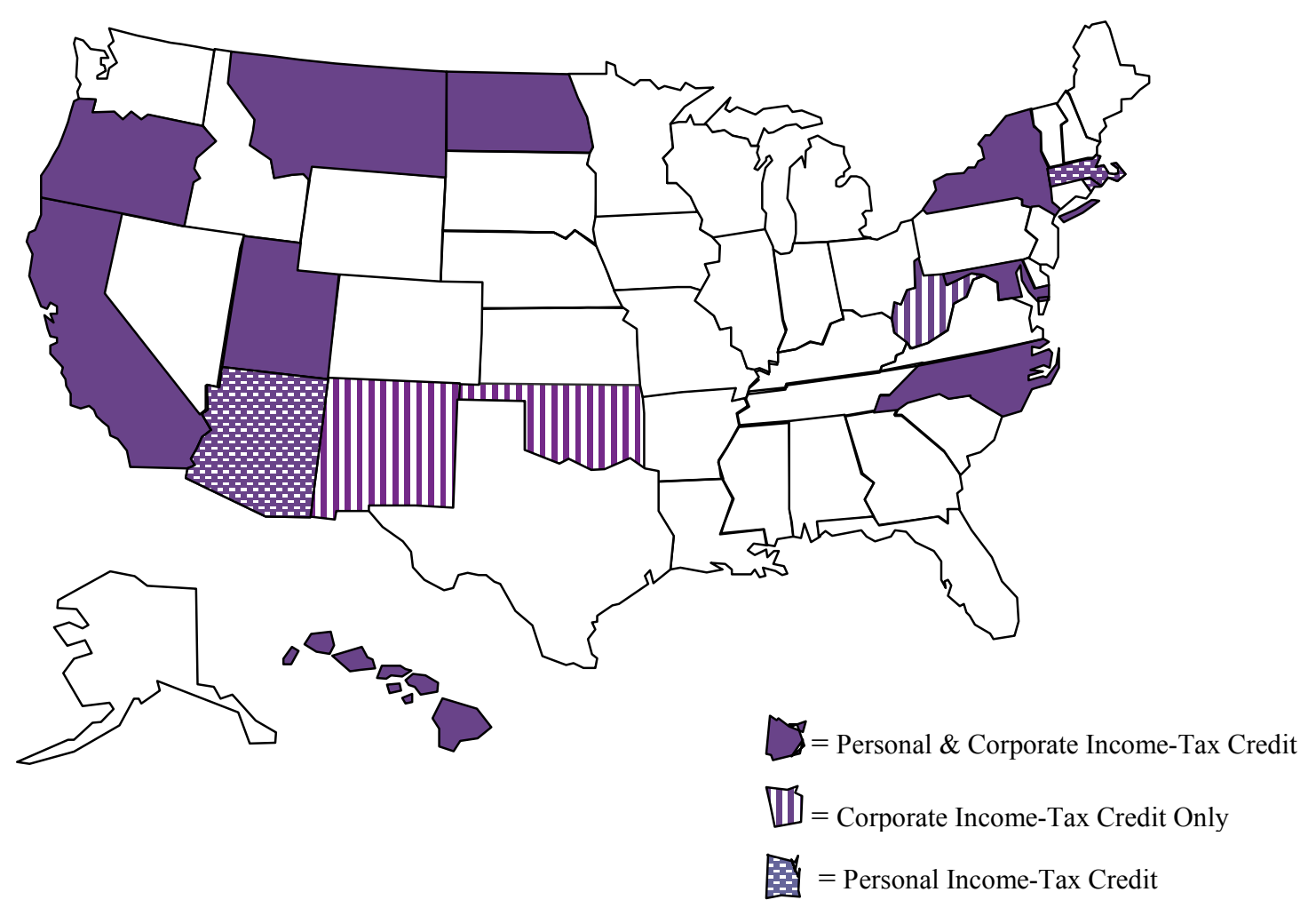

Figure 1: States with Income-Tax Credits for Renewable Energy Technologies

\footnotetext{
* This number does not include tax credits for alternative fuels or alternative-fuel vehicles that may use renewable fuels.

${ }^{\dagger}$ The nine states offering both personal and corporate tax credits are California, Hawaii, Maryland, Montana, New York, North Carolina, North Dakota, Oregon, and Utah.

* Arizona, Hawaii, Maryland, Massachusetts, Montana, New Mexico, New York, North Carolina, North Dakota, Ohio, Oklahoma, Oregon, Utah, Rhode Island, and West Virginia.
} 
West Virginia, New Mexico, and Oklahoma offer the incentive only as a corporate tax credit, while Arizona, Rhode Island, and Massachusetts ${ }^{*}$ offer tax credits against personal income tax only. This represents a significant increase since 1997, when only eight states had personal and/or corporate tax credits. ${ }^{4}$ Three states offer production tax credits: Oklahoma and New Mexico recently enacted corporate production tax-credit legislation for large-scale systems of at least $50 \mathrm{MW}$ and $20 \mathrm{MW}$, respectively. Oregon also has a performance-based component in its residential tax-credit program. Variations among technology eligibility, incentive amount, and other state tax-credit features are discussed below.

Eligible Technologies. All but three of these 15 states consider both solar and wind technologies eligible for the incentive. Oklahoma includes only wind, hydro, and geothermal as eligible technologies, while West Virginia offers the incentive only to utilities using windpower generation. On the other hand, neither New York's PV tax credit nor its Green Buildings tax credit applies to wind. About a third of the states with tax credits consider biomass and hydro as eligible technologies, and fuel cells appear in the list of eligible technologies in several of the more recently enacted or amended tax credit laws, such as those in Maryland, Montana, and Oregon. The states offering tax credits to the broadest array of renewable energy technologies are Montana, North Carolina, Oregon, and Utah.

Eligible Applicants. In general, individuals who pay state personal-income taxes and businesses that pay state corporate income taxes are eligible for a tax credit in states that offer them. As mentioned previously, nine states offer both personal and corporate tax credits, while three states offer only a personal-tax credit, and three others offer only a corporate tax credit.

Incentive Amount and Duration. The challenge for tax credits is to offer the right amount of incentive for the appropriate length of time. Uncertainty in the size and permanency of tax credits can have unintended negative effects on the renewables market. Generous incentives that cause a sharp increase in demand may overwhelm a fledgling industry infrastructure, causing supply and quality problems. And, recalling the devastation many solar businesses experienced when federal and some state tax credits expired in 1985, there is a concern that abruptly eliminating the incentive before the industry and the marketplace are weaned off it would yield similar results. ${ }^{5}$ States vary widely with respect to these parameters.

Incentive levels range from $10 \%$ to $35 \%$ of equipment and installation costs for both personal and corporate income-tax credits. Maximum incentive amounts range from $\$ 1,000$ to $\$ 10,500$ for residential systems, and from $\$ 1,000$ to no limit for commercial systems. Most tax credits must be claimed in the first year of production, allowing for any remaining credit to be carried over to the subsequent five, and in a few cases, 10 years. Maryland's tax credit for solar-energy equipment is an exception in that applicants cannot carry over unused credit to subsequent years. Conversely, Oregon and North Carolina require that corporate tax credits be taken in installments spanning five years, beginning with the year the property is placed in service. Three states - California, Oklahoma, and Rhode Island - have declining incentive amounts over time. Ideally, tax credits will help the market expand and lower costs,

\footnotetext{
* Massachusetts has a 100\% corporate deduction for solar and wind.
} 
reducing the need for incentives over time. Gradually decreasing incentives over time may help smooth the transition to a sustainable market without the need for financial incentives.

The duration of tax-credit availability ranges from four to six years in Maryland (Clean Energy Incentive tax credits), New York (Green Building tax credit), California, Rhode Island, and Utah; to 10 to 13 years in Hawaii, Maryland (Green Building tax credit), North Dakota, New Mexico, and Oklahoma. Oregon's and Massachusetts' credits have been in effect since the late 1970s. Montana's and New York's (PV tax credit) also do not have an expiration date.

Quality Assurance. Although PTCs encourage performance by linking the incentive to energy production, ITC programs use other mechanisms to ensure adequate performance. Current state tax-credit programs vary widely with respect to system quality and performance provisions. At one end of the spectrum, North Dakota does not specify any requirements, while Maryland and Massachusetts authorize the tax-credit administrator to develop standards. New York requires that applicants secure net metering agreements with their utility and comply with government and industry installation and operating standards, but no documentation is required to claim the credit.

California and Hawaii do not provide detailed performance standards within the legislation, these states have separate solar-specific equipment certification and contractor licensing requirements. Two other states with tax credits - Hawaii and Oklahoma - also have equipment certification standards and/or special contractor licenses to help ensure adequate performance. North Carolina lacks these state requirements but provides detailed equipment standards within the tax-credit legislation.

More stringent quality assurance is required in Utah, Rhode Island, and Oregon. These states require that applicants obtain certification prior to (Oregon) or following installation (Utah, Rhode Island) of the system to qualify for the tax credit. Utah's and Rhode Island's tax-credit applications are quite detailed - similar to rebate applications in some states. Both states require proof of purchase and technical details. Rhode Island also requires a copy of the interconnection agreement and permits (and the application certification process may include an inspection), while Utah requires an estimate of energy and money savings.

\section{Buy-Downs}

Government-funded buy-down programs in the form of rebates or other cash incentives are used to encourage the installation of renewable energy technologies by reducing or "buyingdown" initial equipment costs. The term "buy-down" is most often used for reductions in the bottom-line cost to purchasers, while "rebate" is used for a payment issued to the purchaser after the system has been installed. In this report, the term "buy-down" will be used to refer to these types of incentives. The rationale for using buy-downs is that the incentive can stimulate deployment of renewables despite high prices early on in technology development, thereby encouraging manufacturers and distributors to accelerate investment. Ideally, this raises production levels, which in turn decreases prices and expands markets. Early sales help develop the necessary infrastructure and awareness to support larger, nonsubsidized markets in the future. ${ }^{6}$ 
Direct cash incentives offer several advantages over tax credits. First, the inability of consumers to absorb the full value of a tax credit can be a substantial barrier to the effectiveness of a tax credit as a tool to promote renewables. Direct incentives have no such problem. Second, unlike tax incentives, direct cash payments can be competitively neutral and accessible to a broader range of recipients. ${ }^{7}$ Program participants such as government agencies, municipal utilities, nonprofit organizations and other nontaxable entities can serve as valuable technology-demonstration venues. Finally, details on program participation, technology and capacity installed, problems experienced, and solutions employed can be more easily achieved through a buy-down program than through a tax-credit program. State tax departments track few, if any, details on program use.

Drawbacks to cash incentives are varied. Generous incentives that cause a sharp increase in demand may overwhelm a fledgling industry infrastructure, causing supply and quality problems. And, recalling the devastation many solar businesses experienced when federal and some state tax credits expired in 1985 , there is a concern that abruptly eliminating the incentive before the industry and the marketplace are weaned off it would yield similar results. ${ }^{8}$ Furthermore, although buy-downs may have greater appeal to consumers than tax credits, they are often less politically viable because an explicit funding mechanism is required. Such funds, if appropriated, may be easy targets for elimination in times of state budget shortfalls. ${ }^{9}$ Finally, two federal incentives - the production tax credit for wind and closed-loop biomass, and the 10\% business-investment tax credit for solar and geothermal property - are reduced if applicants receive any government grants, financing, or any other credits. Thus, for projects that are eligible for federal incentives, state buy-down funds could be "wasted" by displacing the federal incentives. ${ }^{10}$

There are currently 11 state buy-down programs for renewable energy technologies, all of which have been initiated within the past several years. ${ }^{11}$ Figure 2 shows the states currently offering this type of incentive. A recent review ${ }^{12}$ of state buy-down programs for customercited PV supported by public benefits funds indicates that roughly $23 \mathrm{MW}$ of PV have been reserved under these programs. Variations in program funding, technology and applicant eligibility, incentive amount, and quality assurance methods are discussed below.

Funding and Administration. With the exception of Washington's "Plug and Play" off-grid PV buy-down and Florida's PV rebate, these programs are funded by public benefits funds ${ }^{*}$ and administered by the state's energy office, a third-party fund administrator; or, in the case of New Jersey and Long Island, individual utilities.

Eligible Technologies. All of the buy-down programs fund PV installations, with Minnesota, New York ${ }^{\dagger}$, Pennsylvania ${ }^{\ddagger}$, and Washington targeting PV exclusively. Five programs also fund wind, three programs include solar thermal as an eligible technology, and two programs offer buy-downs for fuel cells. Wisconsin's "Cash-Back Reward" offers the incentive to the widest variety of renewable energy technologies - solar thermal, photovoltaics, wind, biomass, hydroelectric, and geothermal heat pumps.

\footnotetext{
* Also known as clean energy funds. These funds are generated from a small wires charge on electric utility customers, predominantly in states that have undergone electric utility industry restructuring.

Both the NYSERDA and LIPA programs target PV technology.

* The Solar PV Program administered by the Sustainable Development Fund is available in PECO's service territory.
} 


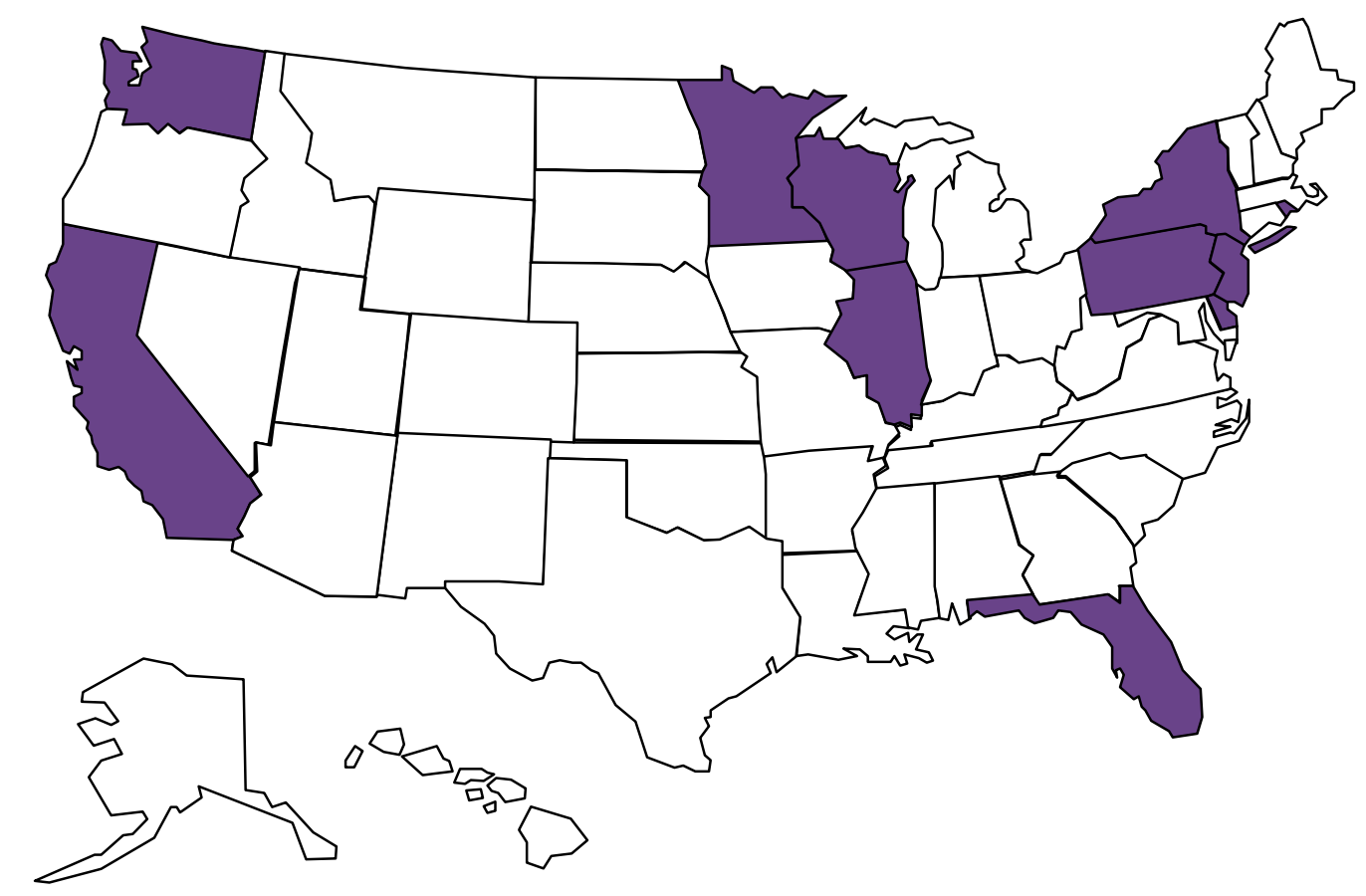

Figure 2: States with Buy-Down Programs for Renewable Energy Technologies*

Eligible Applicants. With the exception of New York's Residential PV Program offered by NYSERDA, all of the buy-down programs are available to residents and businesses. In addition to these sectors, Florida, Illinois, Washington, and Wisconsin extend eligibility to government entities, institutions, and nonprofits. Florida allows utilities to apply for rebates as well.

Incentive Amount. Incentive levels range from $\$ 1.50$ per watt (W) to $\$ 6 / \mathrm{W}$, with most states setting either a maximum expenditure of $20 \%$ to $60 \%$ of system cost or a maximum total dollar amount. In some states, the incentive amount varies based on system size or technology. For example, New Jersey's incentive is based on system size, with higher buydowns available for smaller systems $(\$ 5 / \mathrm{W})$ than for larger systems $(\$ 3 / \mathrm{W})$. Rhode Island offers $\$ 1.50 / \mathrm{W}$ for wind energy systems but $\$ 3 / \mathrm{W}$ for photovoltaics. Wisconsin's incentive is based on expected production and therefore varies based on technology, size, and other factors. Buy-down incentives currently available are typically more generous than tax credits.

Quality Assurance. Technical and performance requirements vary widely among programs. Illinois, New York's Long Island Power Authority, and Rhode Island impose few

\footnotetext{
* They are California, Delaware, Florida, Illinois, Minnesota, New Jersey, New York (includes separate buydowns offered by the New York State Energy Research \& Development Authority's (NYSERDA) Residential PV Program and the Long Island Power Authority), Pennsylvania, Rhode Island, Washington, and Wisconsin. See http://www.dsireusa.org. Florida's PV rebate program is included in this count even though funding was exhausted in January 2002; this program is a case-study subject in this report.
} 
requirements; although, as the Illinois case study reveals, Illinois added requirements after some early systems were installed improperly. California, Florida, New Jersey, and Pennsylvania are much more stringent. California and Florida require PV installers to possess a solar-specific license. Pennsylvania and SunWize (in New York's Residential PV Program) require the use of a participating contractor from a pre-certified list. ${ }^{13}$ Florida not only requires a pre-certified installer but also requires that PV systems be preapproved by the Florida Solar Energy Center and undergo monitoring to evaluate performance.

Two buy-down programs initiated during the past year have incorporated performance-based elements into the incentive. Pennsylvania offers a moderate $\$ 3 / \mathrm{W}$ buy-down of up to $\$ 6,000$, but pays the system owner $\$ 1 / \mathrm{kWh}$ (up to $\$ 2,000$ ) at the end of the first year of production. This production incentive corresponds to about an extra $\$ 1 / \mathrm{W}$ for a $2-\mathrm{kW}$ system. The system installer receives a payment as well-\$0.10/kWh (up to $\$ 250$ ). Wisconsin employs a different model, calculating the incentive amount using a technology- and system-specific formula to reward projected rather than actual production. A wind turbine rated at $10 \mathrm{~kW}$, for example, would receive $\$ 0.45$ per $\mathrm{kWh}$ generated in an average year. For PV systems, the reward is $\$ 2$ per kWh of estimated annual electricity production (up to $50 \%$ of project costs).

\section{Low-Interest Loans}

Government-subsidized loans are used to encourage the installation of renewable energy technologies by helping customers overcome the financial barrier associated with high upfront equipment costs. Interested, but cash-challenged customers who could not otherwise purchase a system outright can buy one with the help of such loans, which typically provide lower interest rates, more favorable terms, and lower transaction costs relative to private lending arrangements. Furthermore, such programs may be more politically viable than cash incentives. ${ }^{14}$ In fact, they can even become self-sustaining through a revolving fund mechanism. Many design and implementation options exist; loan programs can be fashioned to achieve a specific goal or to operate under various constraints.

There are several challenges to loan programs. First, financing programs typically do not result in large enough cost savings to spur significant renewables development in-and-ofthemselves. ${ }^{15}$ Second, businesses may have confidentiality concerns when dealing with the state, and may not be willing to disclose financial information needed to secure a loan. One method of avoiding this potential pitfall is to administer the loan through private lending institutions. ${ }^{16}$ Finally, two federal incentives - the production tax credit for wind and closedloop biomass and the $10 \%$ business investment tax credit for solar and geothermal property - are reduced if recipients receive any other government grants, financing or any other credits. Thus, for projects that are eligible for federal incentives, state loan funds could be "wasted" by displacing the federal incentives. ${ }^{17}$

There are at least 22 active loan programs in 19 states that provide low-cost financing for renewables. Six of these programs have been initiated within the past two years. Figure 3 shows the states currently offering such loans. The programs are similar in that most have a broad technology focus, but they vary widely from state to state in terms of funding mechanisms and total amount available, incentive level, and eligible recipients. State loanprogram characteristics are described below. 


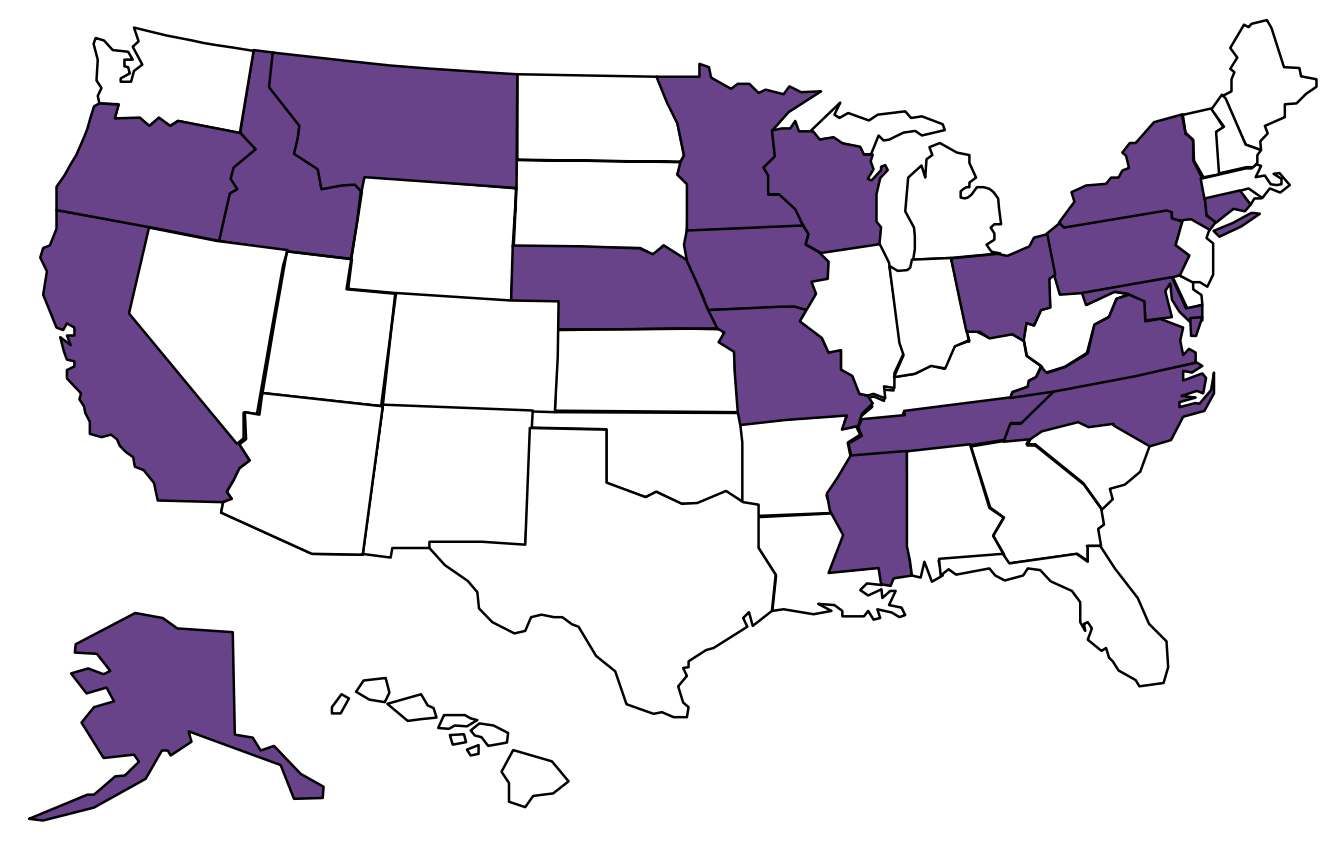

Figure 3: States with Loan Programs for Renewable Energy Technologies*

Funding. Funding for loan programs originates from a variety of sources. Some programs are funded by revolving loan funds, which were established with petroleum violation ("oil overcharge") escrow funds; while others are funded through annual appropriations, the sale of bonds, or air-quality noncompliance penalty fees. More recently established programs such as those in New York (NYSERDA and LIPA), Ohio, and Wisconsin are funded by a system-benefits charge. Total funding for loan programs varies as well, with some programs operating with as little as $\$ 200,000$ per year, while others lend up to $\$ 200$ million per year.

Another point of comparison among loan programs is the extent to which they tie in with and leverage funds from private lending sources. Programs in Iowa, Mississippi, Minnesota, Nebraska, New York, Ohio, Pennsylvania, and Wisconsin all work with private lenders. Other programs are administered directly through state agencies.

Eligible Technologies. While the majority of loan programs promote energy efficiency improvements in addition to renewable energy technologies, a handful of states have designed programs specifically for the promotion of renewables, including Idaho, Iowa, Minnesota, Montana, Ohio, and Wisconsin. Renewable energy technologies eligible for nearly all of the loan programs encompass a broad scope, typically including solar, wind, biomass, and small hydro technologies. Minnesota's focus on wind development and Maryland's decision to limit eligibility to solar technologies in its state government and

\footnotetext{
* They are Alaska, California, Connecticut, Idaho, Iowa, Maryland, Minnesota, Mississippi, Missouri, Montana, Nebraska, New York (NYSERDA and LIPA), North Carolina, Ohio, Oregon, Pennsylvania, Tennessee, Virginia, and Wisconsin. See www.dsireusa.org.
} 
community loan programs are notable exceptions. In general, loan programs focus on smallto medium-scale projects.

Eligible Applicants. Approximately half of the loan programs apply to homeowners and businesses. Several programs are available only to government and/or nonprofit and institutional entities, including those in Alaska, Maryland, Missouri, and one of Iowa's three programs. Several other states offer loans to residents, businesses, institutions and/or government agencies. Examples include Ohio, Oregon, Nebraska, and North Carolina.

Incentive Amount. Interest rates vary from 1\% in North Carolina and 1.99\% in Wisconsin, to more than $6 \%$ in Virginia and Oregon. NYSERDA's program in New York sets its rate $4.5 \%$ below market rate, while Iowa, Ohio, and Nebraska effectively buy-down half of the interest rate. Some loan programs set rates on a case-by-case basis. Loan repayment terms range from three to 20 years, with some based on individual project needs. Maximum loan amounts for residential applications are typically in the $\$ 10,000$ to $\$ 25,000$ range. Programs financing larger projects cap loan amounts at $\$ 100,000$ to $\$ 500,000$. The exception is Oregon, which can accommodate loans of up to $\$ 20$ million under special circumstances.

Quality Assurance. Loan applications typically involve a technical description, which is assessed by program administrators. Methods for ensuring system performance include the use of preapproved contractors (Wisconsin, New York) and post-installation inspections.

The next chapter provides a summary of observations and lessons learned about the effectiveness of financial incentives derived from a detailed look at 10 programs in six states. Please refer to the appendices for a detailed case study of each program. 


\section{OBSERVATIONS AND LESSONS LEARNED}

This section summarizes observations and lessons learned from the experience of 10 incentive programs in six states with a focus on program effectiveness and the issues that influence it. Programs examined include tax credits, buy-downs, and low-interest loans. Because incentive programs take many shapes - and states vary widely in their socioeconomic, political, and climatic conditions - it is not possible to evaluate similarly structured programs in comparable environments to measure them against one another. Rather, the intention is to evaluate several different programs to identify common themes regarding program effectiveness, which can shape other existing or proposed incentive programs.

Several overarching themes emerged from interviews with stakeholders in the six case-study states regarding issues external to incentive programs, which encourage and discourage the adoption of small-scale renewable energy technologies in their respective states. Illuminating the backdrop against which these incentive programs operate is important in understanding and assessing program performance. Therefore, the discussion below first begins with observations and lessons learned about these external factors that indirectly impact the effectiveness of incentive programs. Following this overview, observations and lessons learned about the effectiveness of tax-credit, buy-down, and loan programs examined in this study will be presented with a focus on programmatic features and issues that influence program effectiveness.

\section{External Factors Impacting Program Effectiveness}

\section{Utility support and cooperation with respect to grid-connected renewable energy technologies can enhance program effectiveness by ensuring a smooth interconnection process. A burdensome and costly interconnection process can severely compromise the value of incentive programs.}

The primary renewable energy policy that is considered to have encouraged participation in Illinois' grant and rebate programs is investor-owned utility ComEd's net-metering experiment and simple interconnection agreement. The utility's support of and cooperation with the Illinois program has smoothed the path to interconnection. In fact, utilities in other parts of the state do not offer easy interconnection and net metering, and grant and rebate recipients in those territories have experienced difficulties securing interconnection agreements.

Like Illinois' program, Florida's PV rebate program has benefited from utility support of grid-tied renewables. This program initially disbursed funds to two municipal utilities; these utilities, in turn, used the funding to provide incentives to their customers. One of these utilities helped fund 10 of 13 systems installed during the program's first year. The other utility used its funding to install PV on more than 10 schools. These systems alone accounted for about $40 \%$ of the total systems installed under the program. These utilities also offer net metering despite the lack of a statewide net-metering law. In fact, most of the systems installed in Florida's program were in municipal utility districts, many of which offer net metering. Securing interconnection agreements with other utilities has been challenging, 
though, and was considered a major barrier to installing PV, according to the program administrator's survey of those who had expressed interest in the incentive program. Florida's experience illustrates the impact utility policies have on the deployment of PV.

In contrast, those interviewed in New York were emphatic in their conclusion that the most significant factor limiting deployment of grid-tied renewables (and thus limiting participation in the state's incentive programs) is the protracted and cumbersome interconnection approval process - particularly in upstate New York. While all interviewees agreed that safety and quality must be assured, they argued that the technical requirements in New York are excessive relative to standards required in other states. The additional testing and administrative obstacles that utilities place on installations have limited the program's impact on the market as a result. One installer reported that she curtailed her efforts in upstate New York as a result of the repeated conflicts with utilities and began to focus on the Long Island market instead. Early adopters frustrated with their experience likely share their disappointment with others, potentially deterring possible users from pursuing a similar project.

Experiences in North Carolina and Iowa also indicated that expensive or onerous procedures required for connecting systems to the utility grid discourage some potential customers from purchasing them.

The case-study states experienced varying levels of difficulty with respect to connecting renewable energy systems to the utility grid. But all stakeholders agreed that a safe, easy, and inexpensive interconnection process is critical for developing a sustainable market.

\section{A weak infrastructure, including a shortage of qualified installers and inadequately trained building inspectors, can discourage consumers from purchasing renewable energy systems.}

Experiences in Illinois suggest that increasing demand for PV before an adequate installer infrastructure is in place can frustrate potential participants and act as a barrier to technology deployment. According to interviewees in Illinois, program participants had difficulty finding experienced installers; and, in some cases, installers who had the ability to install a PV system were perceived as charging an exorbitant amount of money. This has been the experience despite the fact that early in the program, no specific installer qualifications were required. The Midwest PV survey mentioned previously also found that states in that region do not have the PV infrastructure to support widespread use of the technology. The number of manufacturers, dealers, and installers is limited - and basic information about costs, brands, and installations is not easily available.

Training workshops for solar hot-water and PV system installers conducted by the North Carolina Solar Center at NC State University have increased the number of trained professionals during the past few years. However, some installers interviewed noted that an inadequate number of distributors in the state make the ordering, delivery, and assembly processes time-consuming and expensive. Customers who experience a lengthy and expensive process may be likely to share their negative experiences with other potential systems purchasers. 
In some cases, incentive programs do have an impact on the number and quality of installers available. In Florida, where a solar-specific license and preapproval from program administrators are required for contractors installing systems under the incentive program, these stringent requirements limited the number of qualified installers available for program participants. Some potential customers experienced difficulty finding a qualified installer early in the program and cited this as a barrier to installing PV, according to a survey conducted by the program administrator. By the end of the program, there were more than 20 certified installers; but continued funding is currently uncertain, and it is unclear whether those installers will continue to be in demand.

One of the strengths of New York's Residential PV Program is that its goal is not only to reduce the market price of $\mathrm{PV}$, but also to build a network of trained installers.

Administering buy-downs through the dealer networks of two PV distributors has helped develop an infrastructure to serve the demand for PV systems. The downside is that this approach offers limited product choice and has reportedly alienated other dealers who were unable to participate.

\section{Program participants tend to be strongly motivated by noneconomic factors.}

Concerns about environmental issues, a desire to reduce dependence on utilities, high electricity costs, and more recently, electricity reliability and security threats are among the factors motivating consumers to purchase renewable energy technologies. Businesses tend to invest in renewables for on-site use to make a statement about their commitment to a sustainable future or in cases where the payback is within acceptable limits. Most program participants appear to have been interested in renewables for a long time. However, stakeholders agree that even with incentives, the economics of investing in renewable energy technologies still may not be considered attractive enough to generate new interest and stimulate widespread deployment given other obstacles potential customers face.

In Oregon, for example, despite modest solar resources and relatively low energy costs, stakeholders interviewed suggested that progressive attitudes toward environmental and energy-conservation issues-together with an array of supportive renewable energy policies - appear to be driving factors in the implementation of energy efficiency and renewable energy projects.

\section{A more comprehensive renewable energy education campaign may be necessary to increase deployment of renewables.}

An inadequate understanding of the types and benefits of renewable energy technologies in general is still considered a major barrier to adoption of these technologies. Grassroots educational campaigns operated by NY Shines and its counterpart on Long Island, LI Shines, have generated a great deal of interest in renewable energy through their outreach activities and could be considered as models by other states. However, some stakeholders cautioned that some promotional efforts have created unrealistic expectations about equipment costs and electricity production. Stakeholders interviewed from states where energy conservation and renewable energy programs have existed for many years, such as Oregon, did not view a more comprehensive marketing campaign as such a dire need as those in some other states, such as Iowa and Illinois. In fact, a Midwest survey of attitudes toward $\mathrm{PV}^{18}$ found that 
limited knowledge about PV systems among the general public and building professionals are major barriers to the use of PV.

Given the attitudes that appear to play a role in the decision to invest in renewable energy systems as discussed above, many stakeholders suggested that marketing campaigns designed to mold the attitudes of the general public accordingly are necessary. In many cases, the renewable energy industry cannot rely on pitching the technology's cost-effectiveness. Such campaigns should tout the environmental, self-sufficiency, and potential financial benefits of renewable energy systems.

\section{A single financial incentive by itself is not likely to ensure significant market penetration of renewable energy technologies; implementing a set of complementary incentives that may include net metering, low-interest loans, tax credits, property- and sales-tax exemptions, and/or buy-downs, can have a significant market impact relative to the historic small markets for $\mathbf{P V}$ and small wind.}

The six states in this study varied with respect to the number and type of incentives that can work in concert with the programs examined and the degree to which incentives are actually used in a complementary fashion. Coordination and promotion of complementary incentives as a package can serve as an effective marketing tool.

Tax-credit and buy-down programs can be enhanced by complementary financial incentives such as net metering, low-interest loans, and property- and sales-tax exemptions. Some stakeholders interviewed suggested that despite the availability of buy-down incentives, which in some cases reduces system costs by $50 \%$, the price of PV equipment is still a significant barrier to adoption. A low-interest loan, if effectively integrated into a comprehensive program and if approved by private lenders, can help more individuals and businesses who may be unable or unwilling to pay cash up-front.

New Yorkers can take advantage of a $\$ 3 / \mathrm{W}$ buy-down (or $\$ 6 / \mathrm{W}$ on Long Island), lowinterest loan, property-tax exemption, and net metering to reduce the cost of PV systems significantly. Advocates and dealers use the availability package of incentives as a marketing tool. However, the loan has rarely been used - in part, because it is new, but also because consumers have had difficulty finding a participating lender who will finance small-scale projects. As for the property-tax exemption, even some of the individuals interviewed for this study were unaware of its existence. Again, making consumers aware of the incentive is critical. This example illustrates that incentive programs must be well coordinated, and potential participants must be made aware of them.

Oregon has several financial incentives that can work in concert with the tax credit; utility rebates and loans for solar water heaters have played a particularly important role in some regions of the state. On the other hand, only a small fraction of those claiming the tax credit take advantage of the low-interest loan. Furthermore, the property-tax exemption complements the tax-credit and loan programs, but it is unclear whether consumers or businesses are aware of the incentive.

All stakeholders interviewed agreed that a statewide net-metering policy is one of the key complementary policies that encourages the deployment of PV. The ability to connect to the 
utility grid eliminates the costs and maintenance requirements of battery systems, and the financial benefits of receiving credit for electricity generated is considered to be a significant benefit to customer-sited systems. In North Carolina, the lack of net metering is considered a major barrier to increased deployment of renewables by those interviewed. Financial incentives in North Carolina in addition to the tax credit - a property-tax exemption and a low-interest loan - are not well-coordinated with the eligibility guidelines of the tax credit, thus limiting their synergy to a few technologies for a small set of building applications.

And finally, the experience of Iowa's loan program shows how loans can play an important role in supporting renewables development when other complementary and significant financial incentives are at play. In 1996, during the first year of the loan program, the state's renewables set-aside policy required investor-owned utilities to purchase a combined total of $105 \mathrm{MW}$ of their generation from renewable sources at 6.02 cents $/ \mathrm{kWh}$. During this period, the program was over-subscribed because many wind systems were installed to benefit from the production incentive. However, once the requirement was satisfied, interest in the loan program dropped off. Still, even in the presence of a sales-tax exemption for wind-energy equipment, a reduced property tax for wind systems, and a property-tax exemption for solarenergy systems, the loan program has not generated substantial interest. Stakeholders interviewed suggested that financial incentives that offer a greater reduction in up-front costs are necessary to encourage small-scale renewable energy development.

\section{Tax-Credit Programs}

This section presents observations and lessons learned from the experience of four state taxcredit programs regarding program effectiveness and the factors that influence it. The following programs were examined:

$\begin{array}{ll}\text { New York } & \text { Solar Electric-Generating Equipment Tax Credit } \\ \text { North Carolina } & \text { Renewable Energy Tax Credit } \\ \text { Oregon } & \text { Residential Energy Tax Credit } \\ \text { Oregon } & \text { Business Energy Tax Credit }\end{array}$

Table 2 provides an overview of the major program elements in these three states. Note that North Carolina and Oregon offer tax credits to both individuals and businesses, while New York's incentive targets residents. In addition, these programs vary widely in the breadth of technologies eligible for the credit, incentive level, and age of the program. Refer to Appendix B for detailed case studies of each program.

\section{The tax credit is not the primary motivating factor influencing purchasing decisions but often helps "seal the deal".}

Although tax credits are used as a marketing tool, stakeholders interviewed contend that the incentive is not the main driver influencing purchasing decisions. In some cases, interested customers are unaware of the credit when they first contact a dealer, but the credit plays a significant role in the final decision. Installers acknowledge that some customers would purchase systems regardless of the tax credit. Further research would be required to determine what portion of project owners would have installed a system even without the credit. 
Table 2: Overview of Case-Study Tax-Credit Programs

\begin{tabular}{|c|c|c|c|c|}
\hline & New York & North Carolina & Oregon (Personal) & Oregon (Corporate) \\
\hline Type & Personal & $\begin{array}{l}\text { Personal and } \\
\text { Corporate }\end{array}$ & Personal & Corporate \\
\hline Administrator & $\begin{array}{l}\text { NY State Dept. of } \\
\text { Taxation and Finance }\end{array}$ & NC Dept. of Revenue & OR Office of Energy & OR Office of Energy \\
\hline $\begin{array}{l}\text { Eligible } \\
\text { Technologies }\end{array}$ & $\mathrm{PV}$ & $\begin{array}{l}\text { Passive and Active } \\
\text { Solar, Wind, } \\
\text { Biomass, } \\
\text { Hydroelectric }\end{array}$ & $\begin{array}{l}\text { Solar, Wind, Renewable } \\
\text { Fuel Vehicles and } \\
\text { Charging/Refueling, } \\
\text { Geothermal Electric, Fuel } \\
\text { Cells, Energy-Efficient } \\
\text { Appliances, Duct } \\
\text { Systems, Heat Pumps, } \\
\text { Condensing Furnaces, and } \\
\text { Boilers }\end{array}$ & $\begin{array}{l}\text { Solar, Wind, Biomass, } \\
\text { Hydro, Geothermal, } \\
\text { Renewable } \\
\text { Transportation Fuels, } \\
\text { Energy Conservation, } \\
\text { Weatherization, } \\
\text { Recycling, Less- } \\
\text { polluting Transportation } \\
\text { Fuels, and Sustainable } \\
\text { Buildings }\end{array}$ \\
\hline $\begin{array}{l}\text { Eligible } \\
\text { Recipients }\end{array}$ & Residential & $\begin{array}{l}\text { Residential } \\
\text { Commercial } \\
\text { Industrial }\end{array}$ & Residential & Commercial \\
\hline $\begin{array}{l}\text { Credit } \\
\text { Amount }\end{array}$ & $25 \%$ & $35 \%$ & Varies by technology & $\begin{array}{l}35 \% \text { of costs above } \\
\text { conventional technology }\end{array}$ \\
\hline $\begin{array}{l}\text { Maximum } \\
\text { Limit }\end{array}$ & $\begin{array}{l}\text { Lesser of } \$ 1.50 / \text { watt } \\
\text { and } \$ 3,750\end{array}$ & $\$ 1,400-\$ 250,000$ & $\$ 1,500$ & $\$ 10,000,000$ \\
\hline Enacted Date & 1997 & $\begin{array}{l}\text { 1977; revised 1994, } \\
1999\end{array}$ & 1977 & 1979 \\
\hline Effective Date & 1998 & $\begin{array}{l}2000 \text { (current } \\
\text { program) }\end{array}$ & 1978 & 1980 \\
\hline $\begin{array}{l}\text { Expiration } \\
\text { Date }\end{array}$ & None & $1 / 1 / 06$ & None & None \\
\hline Legislation & $\begin{array}{l}1997 \text { NY Statutes } \\
8660 \mathrm{~A}\end{array}$ & $\begin{array}{l}\text { NC General Statutes } \\
105-129.16 \mathrm{~A}\end{array}$ & $\begin{array}{l}\text { OAR } 330-070-0010 \text { to } \\
330-070-0097\end{array}$ & $\begin{array}{l}\text { OAR 330-090-0105 to } \\
330-090-0150\end{array}$ \\
\hline $\begin{array}{l}\text { Avg. \# of } \\
\text { Claims/yr. }\end{array}$ & 95 & 50 in year 2000 & 871 (renewables) & 25 (renewables) \\
\hline $\begin{array}{l}\text { Total Amount } \\
\text { Claimed/yr. }\end{array}$ & $\$ 124,000$ & $\$ 53,261$ in year 2000 & $\$ 931,000$ (renewables) & Not available \\
\hline
\end{tabular}

\section{The choice of administrative agency may impact the effectiveness of the tax credit.}

Tax-credit programs in North Carolina and New York are administered by the state revenue departments, while those in Oregon are administered by the state's energy office. Oregon's experience suggests that there are advantages to administering the credit through the energy office. This arrangement may allow for coordination with the design and administration of other energy programs, including outreach activities and promotional materials.

Furthermore, by administering the program, the agency can track details on number and type of participants, technologies installed, and project costs - all of which allow for better evaluation and modification of the program. 
Oregon's energy office offers to hold a pre-application meeting with applicants considering complex projects. By discussing customers' energy project ideas early in the development of the project, the staff is able to suggest energy-saving ideas and technologies, as well as other types of assistance that the agency can provide.

The trade-off, of course, is that outreach and personal attention increases the cost the program. In Oregon, businesses are charged an application fee to cover the costs of administering the program, while the residential program is funded by a block grant from the U.S. Department of Energy. The residential program benefits through its partnership with the solar industry; the energy office trains contractors to assist consumers with tax-credit certification paperwork and lists them on the agency's Web site.

Outreach and awareness efforts may be a challenge in states that administer the incentive through its department of revenue. It is critical that administrators of other incentive programs and their partners widely promote the tax credit in their marketing materials. For example, the NC Solar Center at NCSU in North Carolina, and the NY and LI Shines programs in New York, are natural conduits for this information and do assist in promoting the incentive within the context of other programs. Installers can make the process easier by providing tax-credit details and appropriate forms to their customers.

3. The percentage of project costs eligible for a tax credit is considered to be adequate to stimulate interest in purchasing systems in these three states; but caps on eligible costs, low maximum amounts for higher cost technologies, and other credit limitations may reduce the effectiveness of the incentive.

North Carolina's tax credit, among the most generous in the country with relatively high maximums, limits to $50 \%$ the amount of credit that applicants can claim from the taxpayer's tax liability for the year. Individuals who do not have a high tax liability are only able to take advantage of a small portion of this credit during the year of installation. Although individuals may carry over the remaining credit amount up to five years, having to spread the incentive over multiple years reduces the overall benefit of the incentive. Eligible nonresidential taxpayers must take the credit over a five-year period. A more immediate incentive may improve the effectiveness of the program.

In Oregon, the tax credit is limited to $\$ 1,500$. While this cap may be adequate for solarthermal systems, higher-cost systems such as PV and wind do not enjoy the equivalent benefit. North Carolina's $\$ 10,500$ maximum for residential renewables provides a greater incentive, the equivalent of $\$ 3.50 / \mathrm{W}$ for a $3-\mathrm{kW}$ system costing $\$ 30,000$. New York's $25 \%$ credit has a slightly higher maximum of $\$ 3,750$ for residential PV systems, but the incentive is capped at $\$ 1.50 / \mathrm{W}$.

\section{Some mechanism for guaranteeing quality is necessary to ensure that states and project owners are investing in systems that perform as designed. Tax-credit programs employ various technology and installer requirements, but it is unclear how these provisions impact program effectiveness.}

Tax-credit programs examined in this study use one or more of the following mechanisms to ensure quality installations: compliance with government and industry standards, contractor licensing, or equipment standards; project approval before or after installation; and/or a 
production-based credit. New York requires that applicants secure net-metering agreements with their utilities and comply with government and industry installation and operating standards, but no documentation is required to claim the credit. There is some question as to whether all systems claimed are actually grid-connected, given industry estimates of gridconnected systems. North Carolina requires that equipment meets standards detailed in the program guidelines and that installers hold the appropriate contractor license (depending on the technology). Oregon's corporate tax-credit program requires certification of projects prior to installation, while the residential tax credit is based on energy saved in the first year for most of the renewable energy technologies. Costs and benefits of different quality-assurance provisions should be examined to identify best practices.

\section{Developing mechanisms for nontaxed entities to take advantage of tax credits can stimulate deployment among these sectors.}

One of the disadvantages of tax credits is that they are not applicable to nontaxed entities such as nonprofits, schools, and government agencies. Oregon offers a unique mechanismthe Pass-Through Option - to rectify this inequity. Nontaxed entities may purchase systems and transfer the credit to a third party (such as a large commercial or industrial company in the community or an energy services company) in exchange for the net present value of the tax credit. Businesses with a tax liability also may choose to use the Pass-Through Option. Because this feature is relatively new, its impact on public-sector deployment of renewables is not known.

\section{Buy-Down Programs}

This section presents observations and lessons learned from the experience of three state buydown programs regarding program effectiveness and the factors that influence it. The following programs were examined:
Florida
Photovoltaics Rebate Program
New York
Residential Photovoltaics Program
Illinois
Renewable Energy Resources Program

Table 3 provides an overview of the buy-down program elements in these three states. Note that all three programs target PV as an eligible technology, with New York and Florida targeting PV exclusively. Eligibility requirements, however, differ. New York's Residential PV Program, as the name suggests, targets the residential sector. The Illinois and Florida programs offer the incentive to a wide variety of sectors. Incentive amounts vary as well, with Illinois at $\$ 6 / \mathrm{W}$, Florida at $\$ 4 / \mathrm{W}$, and New York at $\$ 3 / \mathrm{W}$. 
Table 3: Overview of Case-Study Buy-Down Programs

\begin{tabular}{|c|c|c|c|}
\hline & Florida & Illinois & New York \\
\hline Administrator & FL Solar Energy Center & $\begin{array}{l}\text { IL Dept. of Commerce and } \\
\text { Community Affairs }\end{array}$ & $\begin{array}{l}\text { Two individual PV } \\
\text { distributors contracted by } \\
\text { NY State Energy Research } \\
\text { \& Development Authority }\end{array}$ \\
\hline $\begin{array}{l}\text { Eligible } \\
\text { Technologies }\end{array}$ & PV & $\begin{array}{l}\text { Solar Thermal, PV, (grant } \\
\text { also includes Wind, Biomass, } \\
\text { Hydro, Fuel Cells) }\end{array}$ & PV \\
\hline Eligible Recipients & $\begin{array}{l}\text { Commercial, Residential, } \\
\text { Construction, Utilities, } \\
\text { Schools, Government } \\
\end{array}$ & $\begin{array}{l}\text { Commercial, Industrial, } \\
\text { Residential, Nonprofit, } \\
\text { Schools, Local Government } \\
\end{array}$ & Residential \\
\hline $\begin{array}{l}\text { Buy-down } \\
\text { Amount }\end{array}$ & $\begin{array}{l}\$ 4 / \text { watt; additional } \$ 2,000 \\
\text { for builders }\end{array}$ & $50 \%-60 \%$ ( $\$ 6 /$ watt for $P V)$ & $\$ 3 /$ watt up to $50 \%$ \\
\hline Maximum Limit & $\begin{array}{l}\$ 16,000 \text { residents; } \$ 40,000 \\
\text { comm./public facilities }\end{array}$ & $\begin{array}{l}\text { Rebate: } \$ 5,000 \\
\text { Grant: } \$ 150,000-\$ 2,750,000\end{array}$ & $\$ 7,500$ \\
\hline Effective Date & 1999 & 1999 & 1999 \\
\hline Expiration Date & $1 / 2002$; currently inactive & $12 / 2007$ undergoes review & $12 / 31 / 02$ \\
\hline Program Funding & $\$ 600,000$ for 3 years & $\sim \$ 5 \mathrm{M}$ per year through ' 07 & $\$ 1 \mathrm{M}$ for 3 years \\
\hline $\begin{array}{l}\text { Buy-down \$ } \\
\text { Distributed }\end{array}$ & $\$ 525,000$ in rebates & $\$ 8 \mathrm{M}(\$ 4.25 \mathrm{M}$ for $\mathrm{PV})$ & Not available \\
\hline Capacity Installed & $173 \mathrm{~kW}$ & $\begin{array}{l}24 \mathrm{MW} \text { (693 kW for PV, } \\
\sim 130 \mathrm{~kW} \text { for resid./comm.) }\end{array}$ & $\begin{array}{l}70 \mathrm{~kW}(+130 \mathrm{~kW} \text { planned } \\
\text { for summer 2002) }\end{array}$ \\
\hline
\end{tabular}

\section{Buy-downs can play a significant role in encouraging the deployment of photovoltaic systems.}

Although fewer than 100 PV systems have been installed under each of the three buy-down programs during their first three years, the incentive programs have served as important catalysts in increasing the number of PV systems installed in their respective states. Most stakeholders interviewed commented that residents participating in the programs have been interested in solar technologies for a long time, and that the availability of the buy-down inspired them to make the purchase. Installers acknowledged, however, that some customers would purchase systems regardless of the financial incentive. Further research would be required to determine what portion of project owners would have installed a system even without the incentive.

Buy-down incentives are poised to play a significant role in developing a sustainable PV market, but numerous barriers have limited their effectiveness at stimulating more widespread use of photovoltaic technologies. These barriers, as well as some program features that have enhanced program effectiveness, are discussed below.

\section{Utility support and cooperation can greatly enhance the effectiveness of a buy-down for grid-connected technologies and are critical to ensure a quick and easy interconnection process.}

Both the Florida and Illinois programs have benefited through partnerships with electric utilities. Florida, which recently completed its program and is awaiting new funding, issued 
grants as part of its program to two municipal utilities, which were used, in turn, to provide incentives to their customers. One of these utility partners helped fund 10 of 13 systems installed during the program's first year-all residential. The other utility used its funding to install PV on more than 10 schools. These utilities also offer net metering despite the lack of a statewide net-metering law. In fact, most of the systems installed in Florida's program were in municipal utility districts, many of which offer net metering. Securing interconnection agreements with some utilities has been challenging, though, and was considered a major barrier to installing PV, according to the results of the program administrator's survey of those who had expressed interest or participated in the incentive program.

The primary renewable energy policy that is considered to have encouraged participation in Illinois' program is ComEd's net-metering experiment and simple interconnection agreement. The utility's support of and cooperation with the Illinois Department of Commerce and Community Affairs has smoothed the path to interconnection. In fact, utilities in other parts of the state do not offer net metering, and grant and rebate recipients in those territories have experienced difficulties securing interconnection agreements. This may help explain why about $80 \%$ of program participants are in ComEd's territory, although further research would be required to determine what other factors may be at play, such as the Million Solar Roofs efforts in Chicago.

In contrast, those interviewed in New York were emphatic in their conclusion that the most significant factor reducing the program's effectiveness is the protracted and cumbersome interconnection approval process. While all interviewees agree that safety and quality must be assured, they argue that the technical requirements in New York are excessive relative to standards required in other states. The additional testing and administrative obstacles that utilities place on installations have limited the program's impact on the market as a result. One installer reported that she curtailed her efforts in upstate New York as a result of the repeated conflicts with utilities and began to focus on the Long Island market instead. Early adopters frustrated with their experience likely share their disappointment with others, potentially deterring possible users from pursuing a similar project.

The case-study states experienced varying levels of difficulty with respect to connecting renewable energy systems to the utility grid; but all stakeholders agreed that a safe, easy, and inexpensive interconnection process is critical for developing a sustainable market. Utility cooperation appears critical to the grid-connected PV market.

\section{Offering generous buy-downs in the absence of an adequate number of qualified installers frustrates consumers and can discourage them from purchasing systems.}

Experiences in Illinois and Florida suggest that increasing demand for PV before an adequate dealer/installer infrastructure is in place can frustrate potential participants and act as a barrier to technology deployment. According to interviewees in Illinois, program participants have had difficulty finding experienced installers; and, in some cases, installers who had the ability to install a PV system charged an exorbitant amount of money. This has been the case despite the fact that early in the program, no specific installer qualifications were required. 
In Florida, where a solar-specific license and preapproval by program administrators are required for contractors installing systems under the incentive program, these stringent requirements limited the number of qualified installers available to program participants. Some potential customers experienced difficulty finding a qualified installer early on in the program and cited this as a barrier to installing PV, according to a survey conducted by the program administrator.

One of the strengths of New York's Residential PV Program is that its goal is not only to reduce the market price of $\mathrm{PV}$, but also to build a network of trained installers.

Administering buy-downs through the dealer networks of two PV distributors has helped develop an infrastructure to serve the demand for PV systems.

\section{Offering buy-downs to support public-sector projects can help jump-start participation in and awareness of the incentive program.}

Both the Illinois and Florida programs offer the incentive to schools, government agencies, and other public entities. In addition, Florida, which recently completed its program and is awaiting new funding, issued grants to two municipal utilities to be used to provide incentives to their customers. One utility program used its grant to install PV on about a dozen schools. Likewise, the Illinois program worked in concert with investor-owned ComEd and the City of Chicago early on in the program to fund about a dozen PV systems on museums and schools in the City of Chicago. Installations on schools and other public facilities can act as valuable demonstration sites and offer opportunities for promotional and educational opportunities.

\section{Incentive amounts, which ranged from $\$ 3 / \mathrm{W}$ to $\$ 6 / \mathrm{W}$ in the case-study states, are generally considered adequate to stimulate interest in purchasing PV systems without devaluing the product. It is unclear what incentive level is optimal, but experience suggests that a high and sustainable incentive level may be required in the program's early years with levels declining as barriers are eliminated and the market matures.}

Stakeholders generally felt that the incentive level was adequate to stimulate interest in purchasing a PV system without devaluing the product. Illinois has the most generous buydown level in the country at $\$ 6 / \mathrm{W}$. New York's is at the lower end of the spectrum at $\$ 3 / \mathrm{W}$, with Florida at $\$ 4 / \mathrm{W}$. Florida's incentive was increased from $\$ 2 / \mathrm{W}$ to $\$ 4 / \mathrm{W}$ during the program because the initial level did not seem to generate as much interest as expected. About 15 of a total 50 had submitted applications before the incentive was increased. Some stakeholders in New York felt that $\$ 3 / \mathrm{W}$ was adequate, while others noted that an even higher level was warranted early in the program. New York's intent was to phase out the incentive over time, but given the slow start to the program, the incentive level is not likely to be reduced in the near future.

There was no consensus on the exact incentive level that states should offer to enhance market development. In general, these states' experiences suggest that a high and sustainable incentive level may be required in the early years, with levels declining as barriers are eliminated and the market matures. 


\section{Uncertain funding may disrupt the progress stimulated by the incentive program; once funding has been depleted, potential participants may hold off on purchasing PV systems in anticipation of renewed funding.}

All of Florida's PV rebate funding has been committed, but the program is still accepting (and receiving) applications for a waiting list. While program officials are hopeful that funding will be renewed, it is possible that those on the waiting list will indeed delay their projects until financial incentives are once again available. Observers suggested that the rebate has played a major role in stimulating homeowners to install systems, and that without the incentive, reduced activity is expected. Similarly, New York's program was scheduled to end after 2002, but the two distributors received an infusion of additional funds to continue the program. Uncertainty in program funding or duration can pose difficulties for the planning efforts of renewable energy businesses.

\section{A burdensome and detailed incentive application form can frustrate or deter potential program participants. Program administrators should make applications as quick and easy as possible without compromising the level of technical and financial details necessary to ensure project feasibility.}

Florida has a lengthy and detailed application process intended to ensure system consistency and quality. This process was described as too burdensome, according to some respondents of the survey conducted by the program administrator. Illinois' rebate application is fairly straightforward (for PV systems less than $2 \mathrm{~kW}$ ), but the grant application required for larger projects has been overwhelming to some homeowners interested in the program, according to one installer interviewed. Many participants in the Illinois program are choosing PV systems greater than $2 \mathrm{~kW}$ and therefore must use the more detailed grant application. While such an application is necessary to ensure technical and financial feasibility for projects that may include landfill gas facilities or wind farms - and program administrators are available for assistance-incentive-program administrators may want to consider a less cumbersome application for residential-scale PV systems.

\section{Some mechanism for guaranteeing quality is important to ensure that states and project owners are investing in systems that perform as designed. Buy-down programs employ various technology and installer requirements, but it is unclear how these provisions impact program effectiveness.}

Buy-down programs examined in this study differed in their approach to ensuring system performance; they used one or more of the following mechanisms: preapproved system designs; preapproved contractors; use of licensed, bonded, and insured installers; and postinstallation monitoring.

Illinois had few provisions at the start of its program, but added requirements for PV installers to be licensed contractors, insured, and bonded after experiencing some system failures early on. Early experience also inspired program administrators to develop a PVinstaller training program. Florida has the most prescriptive quality-control provisions, requiring preapproved systems and installers in addition to post-installation monitoring. This intensive component is part of the overall program mission to monitor system performance and develop solutions to problems with emerging technologies. The program has been successful in identifying and encouraging equipment improvements. New York runs its 
program through two distributors and their dealer networks. The program requires installer training and system monitoring, but collecting performance data from individual dealers has proved challenging.

Developing mechanisms and requirements to ensure adequate system performance without being overly burdensome or cost-prohibitive is a challenge for buy-down programs.

Ensuring quality installation is critical to engender consumer confidence and guarantee that the state is making wise investments. An assessment of the effectiveness of various approaches to quality assurance and their associated costs would be useful as established programs evolve and new ones are implemented.

\section{Loan Programs}

This section presents observations and lessons learned from the experience of three state loan programs regarding program effectiveness and the factors that influence it. The following programs were examined:

$\begin{array}{ll}\text { Iowa } & \text { Alternate Energy Revolving-Loan Program } \\ \text { New York } & \text { Energy \$mart Loan Program } \\ \text { Oregon } & \text { Small-Scale Energy Loan Program }\end{array}$

Although these programs differ in design and implementation, funding mechanism, and length of time in existence, they each consider small-scale, on-site renewable energy systems eligible for financing. The three programs examined use revolving loans, public-benefits funds, and bond sales, respectively. New York has had just more than a year of experience with its loan program, while Oregon's program has been operating for more than 20 years.

\section{Low-interest loans can play an important supporting role in the deployment of renewable energy technologies, but do not appear to be a significant driver in market development.}

Based on estimates of the overall number of renewable energy systems installed in the casestudy states, it appears that only a small fraction of system owners have used these states' low-interest loan programs. However, in Oregon and Iowa, program administrators assert that the loan plays a major role in decision-making for those who do use the loan program, particularly for commercial investors. Loans are most effective when coordinated with incentives that reduce up-front costs or with those that mandate the use of renewables.

Further research would be required to determine why those installing systems use other financing mechanisms if they do not purchase equipment outright.

\section{Offering an interest rate significantly lower than the market rate and requiring minimal fees may be necessary to attract interest in loan programs.}

New York's program buys down the market interest rate by $4.5 \%$, resulting in nearly zeropercent financing for many projects due to low market interest rates during the program's first year. Although only a few loans have been issued for renewables, the program was considered to have a successful first year, receiving about 300 applications for energy efficiency. With California's energy crisis and New York's own high electric rates and reliability concerns increasing awareness of energy issues, the generous incentive level was 
considered to be an important factor in encouraging residents and businesses to implement energy efficiency improvements.

Oregon issues few loans for small-scale renewables relative to the number of these systems - primarily solar hot water-installed in the state. With an interest rate of more than $6 \%$ and up to $\$ 500$ in application fees, program administrators suggested that for these types of projects, applicants can often find more favorable terms - and less paperwork - by using home-equity loans or other means. Of course, some individuals and businesses purchase systems outright. The availability of zero-interest loans from some utilities and the incorporation of technologies such as solar water heaters in new construction also may help explain why more residents and small businesses do not use the loan program.

The Oregon Office of Energy has considered a revolving-loan fund to provide a better vehicle for smaller loans. As the current loan program builds up equity, there may be an opportunity to offer loans as low as 3\% interest for the residential or niche market. The state's recently established public-benefits fund represents another potential funding source for a low-interest loan better suited to small-scale projects.

Table 4: Overview of Case-Study Loan Programs

\begin{tabular}{|c|c|c|c|}
\hline & Iowa & New York & Oregon \\
\hline Administrator & Iowa Energy Center & NYSERDA & Oregon Office of Energy \\
\hline $\begin{array}{l}\text { Funding } \\
\text { Mechanism }\end{array}$ & Revolving Loan & Public-Benefits Fund & Bond Issue \\
\hline $\begin{array}{l}\text { Lending } \\
\text { Organization }\end{array}$ & Participating private lenders & $\begin{array}{l}\text { Participating private } \\
\text { lenders }\end{array}$ & Oregon Office of Energy \\
\hline $\begin{array}{l}\text { Eligible } \\
\text { Technologies }\end{array}$ & $\begin{array}{l}\text { Solar, Biomass, Wind, } \\
\text { Small Hydroelectric }\end{array}$ & $\begin{array}{l}\text { Solar, Wind, Energy } \\
\text { Efficiency }\end{array}$ & $\begin{array}{l}\text { Solar, Wind, Biomass, Hydro, } \\
\text { Alt. Transportation Fuels, } \\
\text { Geothermal, Waste, Cogen. } \\
\text { Waste Heat Recovery, } \\
\text { Recycling, Energy Conservation }\end{array}$ \\
\hline $\begin{array}{l}\text { Eligible } \\
\text { Recipients }\end{array}$ & $\begin{array}{l}\text { All sectors except } \\
\text { nonregulated utilities }\end{array}$ & $\begin{array}{l}\text { Residential, Multifamily, } \\
\text { Commercial, Industrial, } \\
\text { Agricultural, Nonprofit } \\
\end{array}$ & $\begin{array}{l}\text { Residential, Commercial and } \\
\text { Industrial, Schools, Government, } \\
\text { Utilities, Tribes, and Nonprofits }\end{array}$ \\
\hline $\begin{array}{l}\text { Incentive } \\
\text { Amount }\end{array}$ & $\begin{array}{l}50 \% \text { of the project cost } \\
\text { financed at } 0 \% ; 20 \mathrm{yrs} \text {. }\end{array}$ & $\begin{array}{l}4.5 \% \text { below market rate; } \\
5 \text {-year term }\end{array}$ & $\begin{array}{l}\$ 20,000 \text { - } \$ 20 \text { million; } 10-15 \\
\text { yrs }\end{array}$ \\
\hline Maximum Limit & $\$ 250,000$ & $\begin{array}{l}\$ 500,000 \text { ( } \$ 5 \text { million for } \\
\text { multifamily projects) }\end{array}$ & No Limit \\
\hline Effective Date & 1996 & 2000 & 1981 \\
\hline Expiration Date & None & $6 / 30 / 03$ & None \\
\hline Funding & $\begin{array}{l}\$ 5.9 \mathrm{M} \text { initial funding; } \\
\text { revolving account }\end{array}$ & $\$ 1.9 \mathrm{M}$ per year & $\begin{array}{l}\$ 100 \mathrm{M} \text { bond authority/ } \\
\text { biennium }\end{array}$ \\
\hline Amt. Disbursed & $\$ 3.3 \mathrm{M}$ & $\$ 1.2 \mathrm{M}(\sim \$ 10 \mathrm{~K}$ for $\mathrm{PV})$ & $\begin{array}{l}\$ 291 \mathrm{M}(\$ 180 \mathrm{M} \text { for } \\
\text { renewables })\end{array}$ \\
\hline \# of Loans & 22 & 260 (4 for renewables) & 530 (175 for renewables) \\
\hline $\begin{array}{l}\text { Renewables } \\
\text { Installed }\end{array}$ & $\begin{array}{l}\text { 477,000 MWh annual } \\
\text { generation }\end{array}$ & $\sim 8 \mathrm{~kW}$ & $\begin{array}{l}446 \text { GWh annual generation; } \\
\text { million MMBTU saved }\end{array}$ \\
\hline
\end{tabular}




\section{Loan programs that partner with private lending institutions benefit by leveraging funds from private sources, but lenders are often reluctant to issue small loans, limiting the program's effectiveness in encouraging small-scale renewables deployment. Outreach and educational activities targeting the banking industry are critical to success for these programs.}

Both New York's and Iowa's programs require applicants to secure financing from private lenders. This arrangement allows loan programs to leverage funding from private sources and takes advantage of their expertise in administering loans. New York's program has leveraged about $\$ 10$ in loans for every $\$ 1$ in funding, while Iowa's program has leveraged more than $\$ 6$ for every $\$ 1$ in funding. However, the effectiveness of these programs, which have many admirable features, has been compromised by their potential clients' lack of access to financing.

In the case of New York, NYSERDA buys down the interest rate of participating lenders by $4.5 \%$. Despite a growing number of participating banks in the program, consumers have experienced difficulty finding one that will provide small loans for residential PV projects. Frustrating experiences of early adopters are likely to deter others from pursuing financing through this program, and indeed, one installer noted that she stopped informing customers about the program after learning of several such experiences. As the program matures and more banks become involved, it is important to communicate program improvements to the renewable energy industry.

The loan program administrator in Iowa acknowledged similar problems. Iowa's program provides $50 \%$ of the loan at $0 \%$ interest and requires applicants to secure the other half through another source, typically a private lender. Residents seeking loans for corn-burning furnaces, for example, have been largely unsuccessful due to the small loan amount requested.

Oregon's program avoids this problem by financing projects in-house. However, the agency bears a higher administrative cost as a result. This manifests itself in application fees and higher interest rates than other state loan programs. As discussed above, the usefulness of Oregon's loan program for small-scale projects may be limited as a result.

\section{Educating and partnering with renewable energy businesses and advocacy organizations can leverage marketing activities and bolster interest in the program.}

A few negative experiences with the program can taint its reputation in the eyes of dealers and installers - a negativity which they communicate to customers. As a result of some clients' frustrations with the loan programs in New York and Iowa, some installers have affirmatively discouraged or have not encouraged customers to use the programs due to the difficulty in securing financing from private lenders, or the potentially cumbersome application process. As programs mature and evolve, it is important that program administrators supply equipment dealers and installers with updated promotional materials, including some examples portraying the advantages of low-interest financing.

Furthermore, program administrators should communicate with equipment vendors and installers to inform them about banks that offer favorable terms for small-scale projects. Stakeholders interviewed in Oregon noted that communication and partnerships with 
equipment vendors and installers, utilities, and engineering and architectural firms have played an important role in educating the potential participants in Oregon's energy programs.

5. Some mechanism for guaranteeing quality is necessary to ensure that states and project owners are investing in systems that perform as designed. Loan programs employ various technology and installer requirements, but it is unclear how these provisions impact program effectiveness.

Iowa's and Oregon's loan applications undergo a technical and financial review by program staff. These programs have in-house technical expertise to establish technical requirements on a case-by-case basis. In general, New York's program uses a list of preapproved measures, and custom measures must undergo a technical and financial review. Although PV is a prequalified technology, problems with improper installation of the first couple of systems resulted in additional requirements; residents must now participate in New York's Residential PV Program to qualify for the loan program, and trained installers and postinstallation monitoring are employed to ensure quality installations. In the process, these applicants also qualify for a $\$ 3 / \mathrm{W}$ buy-down. Further research is required to determine costs and benefits of the various quality-assurance mechanisms and to identify best practices. 


\section{CONCLUSIONS AND RECOMMENDATIONS}

Developing sustainable markets for renewable energy technologies is a complex and challenging task. Advancement of these technologies faces informational, financial, and institutional barriers. As this study illustrates, states have adopted an assortment of approaches to reduce financial barriers to the deployment of renewables. Incentive programs examined in this study have had mixed success, with performance influenced by a variety of factors both internal and external to the program itself. Although the aggregate impacts of the incentives in the case-study states have been modest, it is important to note that some programs, particularly the relatively new buy-down programs, have played significant roles in increasing the number of grid-connected photovoltaics installed in their respective states. It has become clear that a smooth interconnection process is critical for success of these programs. Low-interest loans can play an important supporting role when coordinated with other significant incentives. Tax credits, if combined with outreach and education efforts and other complementary incentives such as net metering, also can help drive the market for renewables. Clearly, states cannot expect any one of these incentives alone to remove all the barriers to renewable energy technology development.

This study provides some potent examples of program design and implementation elements that have enhanced and limited program effectiveness. Although the unique socioeconomic, political, climatic, and infrastructure conditions at play within each state make a simple and uniform approach to incentive programs unworkable, states should consider the guiding principles below as they create new programs or modify existing ones. These principles reaffirm recommendations made by other reviews of financial incentives during the past three decades. Policy makers should consider setting the following conditions for incentive programs:

\section{Work with other state programs and relevant stakeholder groups to educate the public about renewable energy technologies and to market the incentive program.}

Educating the public about renewable energy technologies in general - their benefits, costs, and applications - is a critical first step to transforming the market. Programs must incorporate an outreach and marketing component to make eligible participants aware of available financial incentives. Supplying other related state programs, advocacy groups, the renewable energy industry, and other stakeholder groups with promotional material (including examples of the costs and benefits of participating in the program) can leverage resources to increase awareness.

\section{Offer a generous incentive with stable, long-term funding, which decreases over time as the market matures.}

Programs should have a long-term, stable funding mechanism not subject to annual appropriations. Incentives should be generous, particularly early in the program, to generate significant interest. Programs that offer the incentive to a variety of technologies should consider setting maximum incentive limits based on relative costs of technologies. For example, the incentive cap for photovoltaic technologies may need to be higher than for small wind or solar hot-water systems. As the market matures and demand increases, 
incentives should be gradually decreased. Further research is required to determine what level of incentive is appropriate to stimulate the deployment of various technologies.

\section{Design an easy and concise application process without compromising quality assurance.}

Program administrators should design as simple an application process as possible without compromising the level of detail required to assess project feasibility and be prepared to assist participants in this effort. Providing detailed program information and relevant forms on the program Web site and partnering with dealers and installers to provide customers with the appropriate application materials can streamline the process for participants. Program administrators should consider enlisting installers to assist in submitting application materials for their customers. In return, program administrators can provide contact information for these dealer/installer partners on the program Web site and to interested customers.

\section{Establish a consistent but cost-effective quality-assurance mechanism to protect consumers by guaranteeing adequate system performance.}

Potential tools may include one or more of the following activities: linking awards to system performance; requiring minimum equipment standards; requiring the use of preapproved systems and/or installers, certifying projects as eligible for the incentive prior to installation; and/or validating system performance through post-installation monitoring. Areas for future research include evaluating the costs and benefits of the various approaches.

The effort currently underway for developing a voluntary national certification program for solar electric practitioners, which is spearheaded by the North American Board of Certified Energy Practitioners (NABCEP), the Institute of Sustainable Power (ISP), and the Interstate Renewable Energy Council (IREC), has significant implications for existing and future incentive programs that choose to require the use of certified installers for PV projects. To the extent that this certification program creates a large pool of highly skilled PV installers to serve the demand created by incentive programs (without increasing costs significantly), it can serve as a critical tool for guaranteeing adequate system performance and engendering consumer confidence in the technology.

\section{Incorporate incentives into an overall infrastructure-development strategy.}

Financial incentives should be considered one element in a holistic program to create a sustainable market for renewable energy technologies. Coordinated activities should include developing product-distribution channels and boosting the number of qualified installers. Gaining cooperation from utilities to ensure a smooth and standardized interconnection process for grid-connected technologies and educating building inspectors, realtors, insurers, bankers, and other stakeholders who may participate in or have authority over the process of deploying renewable energy technologies is critical for program success. States with publicbenefits funds to support renewable energy development may have the best opportunities to create such complementary programs. Dedicated and stable funds for renewable energy may enable a more strategic approach to market development. 


\section{Develop a coordinated package of incentives.}

A single financial incentive it not likely to have a significant market impact on its own. Policy makers should design a package of complementary financial incentives aimed at reducing market price, life-cycle costs, or other financial barriers. These may include tax credits, buy-downs, low-interest loans, net metering, property-tax exemptions, and sales-tax exemptions.

\section{Allow flexibility for program modifications.}

Program administrators should have the flexibility to adjust program requirements, eligible technologies, and other features in response to market or customer needs.

\section{Track the details of program use.}

Finally, policy makers should set conditions for program administrators to track details on program participation in terms of the number and types of recipients, technologies supported, project costs, funding distributed, and energy production or cost savings. This information heightens the ability of program administrators, policy makers, and analysts to evaluate costs and benefits of incentive programs and for decision makers to modify the program accordingly.

Financial incentives are an important tool that can help individuals and businesses overcome the barrier of high initial equipment costs for these technologies. Yet, to be effective, these incentives should be considered as one component in a comprehensive approach to creating a sustainable market. Without other supportive policies - including education and outreach programs, a standardized and quick interconnection process for grid-connected systems, and complementary financial incentives (tax incentives, net metering, and low-interest financing) - the effectiveness of financial-incentive programs in stimulating market development will be compromised. Addressing these needs and challenges requires partnerships and alliances among program administrators, advocates, equipment dealers and installers, lending institutions, utilities and public utilities commissions, and others who have authority over the financing or installation process. 
Appendix A: Tax-Credit CaSe Studies 


\section{NEW YoRK Solar Electric-Generating Equipment Tax Credit}

\section{Summary of Findings}

New York's tax credit for residential solar-electric systems is one of several key policies supportive of the residential photovoltaics (PV) market. During the first three years of the program, 284 residents claimed a tax credit, although some of these claims were likely to be carryovers from the previous year. The tax credit appears to play an important role in some consumers' decisions to purchase a solar-electric system, according to some interviewees. Based on the estimated number of PV systems installed in the state, it appears that eligible residents take advantage of the credit. In fact, more residents have claimed the credit than have used buy-down programs available through the New York State Energy Research and Development Authority (NYSERDA) or Long Island Power Authority (LIPA).

Despite the existence of complementary financial incentives, the cumbersome interconnection process - particularly in upstate New York-is considered the primary barrier limiting deployment of residential photovoltaics. Other factors discouraging investment in PV include high equipment costs and inadequate public understanding about the benefits and costs of PV. Residents who install PV tend to be motivated by concerns about energy security, a desire to reduce dependence on utilities, environmental stewardship, and high electricity costs.

Strengths of this tax credit program are:

- a valuable $25 \%$ credit;

- coordination with other residential PV incentives, which facilitates promotion by some organizations as part of a larger package of incentives;

- a provision to carry over unused credit for up to five years;

- a simple application process; and

- the absence of an explicit program-expiration date.

The credit's limitations include:

- weak quality-assurance measures;

- a lack of outreach and education;

- a maximum incentive amount of $\$ 1.50 /$ watt; and

- the reduction of the credit by the NYSERDA and LIPA buy-down incentives.

Given that this tax incentive is not administered by an agency charged with promoting the incentive and educating the public about renewables, it is critical that administrators of other incentive programs and their partners widely promote the tax credit in their marketing materials. Installers can make the process easier by providing tax-credit details and appropriate forms to their customers. Educating consumers about renewable energy technologies and the availability of incentives (as well as achieving a smooth and efficient interconnection process) will be a continual challenge, requiring partnerships and alliances for program success. 


\section{Program Overview}

Background. Passed by the New York legislature in August 1997, the Solar Choice Act created the "Solar Electric Generating Equipment Tax Credit," allowing residential customers to claim a credit of $25 \%$ of the purchase and installation costs of a qualifying photovoltaic system with a maximum credit of $\$ 3,750$. The goal of the legislation is to encourage private investment in renewables, stimulate economic growth in the state, diversify the state's energy resources, and improve the state's environment. The credit is allowed for tax years beginning on or after January 1, 1998. Included in the legislation is a provision for the net metering and interconnection of the photovoltaic equipment to the utility grid, thereby providing additional benefits to the homeowner.

Eligible Technologies. Photovoltaic systems with a rated capacity of not more than 10 kilowatts $(\mathrm{kW})$ are eligible provided that the system generates electricity for residential use and is connected to the electric utility's transmission and distribution facility ("interconnected"). The equipment must be installed and used at the taxpayer's principal residence in New York.

Eligible Applicants. Residential electric utility customers who pay New York state income taxes are eligible for the tax credit.

Incentive Amount and Terms. The credit is $25 \%$ of the cost of equipment and installation of photovoltaic systems, with a maximum credit of the lesser of $\$ 1.50$ per watt (W) of rated capacity or $\$ 3,750$. Qualified expenditures include costs for materials, labor for on-site preparation, assembly and original installation, architectural and engineering services, and designs and plans directly related to the construction or installation of the solar electricgenerating equipment.

The maximum credit per watt essentially caps qualified expenditures at $\$ 6 /$ watt of rated capacity. For example, if a homeowner installs a 500-watt system for a total equipment and installation cost of $\$ 4,000$, the tax credit would allow a $\$ 3,000$ maximum cost (\$6/watt) and the tax credit would be $25 \%$ of this, or $\$ 750$. Any amount of credit that exceeds a taxpayer's liability in a given year can be carried over to the five taxable years following the year in which the original credit is claimed.

Any amount of the system cost provided by a nontaxable federal, state, or local grant cannot be counted toward the tax credit. A $\$ 3 / \mathrm{W}$ rebate received by a participant in the New York Residential PV program is an example of such a grant. In the example used above, the rebate of $\$ 1,500(500 \mathrm{~W} \times \$ 3 / \mathrm{W})$ would be subtracted from the system costs of $\$ 4,000$ before calculating the tax credit. The tax credit would then equal $25 \%$ of $\$ 2,500$, or $\$ 625$.

Customers of the Long Island Power Authority, who enjoy a rebate of $\$ 6 / \mathrm{W}^{*}$, would only be able to claim a tax credit of $\$ 250$. Although a $25 \%$ tax credit is considered adequate when the full amount can be claimed, its value is diminished by the LIPA and NYSERDA rebate programs. Furthermore, the benefit of the incentive is restricted by the $\$ 6 /$ watt cap on qualified expenditures, which is distinctly lower than the actual cost of $\$ 8$ to $\$ 10$ per watt.

\footnotetext{
* On December 5, 2001, the rebate was increased from $\$ 3 /$ watt to $\$ 6 /$ watt. The rebate was reduced to $\$ 5 /$ watt for applications received after 7/21/02.
} 
Application Process. Before residents can qualify for the credit, they must enter into a netmetering contract with their electric utility, and the system must be connected to the utility's transmission and distribution grid. Other conditions and limitations set by the electric company also may apply. Residents satisfying these requirements must file New York's Tax Form IT-255, Solar Electric Generating Equipment Credit, along with their state income-tax form to claim the tax credit. IT-255 is a simple, one-page form designed to calculate the amount of credit the resident can claim based on qualified expenditures, expenditure cap, and tax-credit rate. The forms are available for downloading on the state's Department of Taxation and Finance Web site.

Outreach Activities. Residents learn about the availability of the tax credit through individual PV dealers and installers, state and regional outreach efforts, and the Web sites of the New York State Energy Research and Development Authority, the New York Solar Energy Industries Association, the Long Island Power Authority, and the state's Department of Taxation and Finance.

NY Shines, a nonprofit educational program conducted by Pace University School of Law Energy Project, promotes the adoption of grid-tied PV technologies through seminars, speaking engagements at local events, television and newspaper advertising, exhibits, and other promotional events. The program informs consumers about the PV tax credit as well as the Energy \$mart Loan Program, Residential PV Program incentives, and net metering. NY Shines has reached thousands of people in the state and has guided more than 1,000 potential customers to vendors through referrals. NY Shines partners with local colleges, environmental-education centers, county legislatures, cooperative extension services, and the folk music community to educate consumers about solar-electric technology and its benefits. LI Shines - Long Island's counterpart to NY Shines and administrator of the Long Island Solar Roofs Initiative - plays a similar role.

\section{Program Results}

New York's Department of Taxation and Finance tracks the number of claims and the total monetary amount of all claims for the PV tax credit. Table 5 below provides data for the first three years of the incentive.

Table 5: New York Tax-Credit Program Results

\begin{tabular}{|c|c|c|c|}
\hline Year & \# of Claims & $\begin{array}{c}\text { Amount of } \\
\text { Claim }\end{array}$ & $\begin{array}{c}\text { Average } \\
\text { Claim }\end{array}$ \\
\hline 1998 & 63 & $\$ 96,000$ & $\$ 1,523$ \\
\hline 1999 & 140 & $\$ 200,000$ & $\$ 1,429$ \\
\hline 2000 & 81 & $\$ 76,000$ & $\$ 941$ \\
\hline 2001 & Not Available & Not Available & Not Available \\
\hline
\end{tabular}

In 1998, during the first year in which the tax credit and net metering were available, 63 residents took advantage of the incentive. The following year, the NYSERDA and LIPA rebate programs were initiated. Although 1999 saw an increase in claims, some were likely to be carryovers from 1998; that is, residents who did not have a large enough tax liability to claim the entire credit in 1998 were able to carry over the credit to the following year. Even if all 63 of the first tax-credit recipients carried over credit to the following year, at least 77 
new claims were made in 1999. Given that the Residential PV Program buy-down/rebate got off to a slow start that year (see case study on page 80) and only 16 LIPA systems were installed from 1999 to 2001, the increase in claims in 1999 cannot be fully attributed to these additional incentives. Likewise, some of the 81 claims in 2000 were presumably carryovers.

Stakeholders questioned whether all these systems actually are connected to the grid given the difficulties they have faced securing interconnection agreements from New York's utilities. One possible explanation theorizes that concerns about Y2K motivated consumers to buy off-grid systems, and they claimed the tax credit despite not having an interconnection agreement with their utility. Alternatively, consumers chose to install grid-connected systems and claim a tax credit without participating in a rebate program. Since 1999, there have been approximately 34 PV systems installed as part of NYSERDA's Residential PV Program and another 32 systems ${ }^{*}$ installed as part of the LIPA's Solar Pioneers Program. These numbers combined represent less than half the number of tax-credit claims.

\section{Observations and Lessons Learned}

The tax credit plays an important role in some consumers' decisions to purchase a solarelectric system. During the first three years of the program, 284 residents claimed a tax credit, although some of these claims were likely to be carryovers from the previous year. It appears that eligible residents take advantage of the credit based on the estimated number of PV systems installed in the state; in fact, more residents have claimed the credit than have used buy-down programs available through NYSERDA or LIPA. The key factors influencing the effectiveness of this tax credit are discussed below in terms of program design and implementation, availability of complementary financial incentives, infrastructure issues, and other influences.

Program Design and Implementation. Program features considered to have significant influence on program effectiveness are the incentive amount and duration, and outreach activities.

Incentive Amount and Duration. Most stakeholders acknowledged that the amount of the tax credit is adequate given the other incentives available to the residential market. Although the tax credit is partially offset by a rebate, observers suggested that any additional cost reduction is important in encouraging homeowners to make the investment in a PV system. In addition, given that the lifetime of the rebate offering is limited, having a tax credit in place with no stated expiration date assures that a valuable financial incentive is available when the rebate program expires.

In addition to the incentive amount, other attributes that may contribute to the tax credit's effectiveness are the simple and straightforward application process, and the cap on qualified expenditures on a per-watt basis to avoid inflated equipment and installation charges. However, the $\$ 6$ per watt cost cap (based on a maximum credit of $\$ 1.50 / \mathrm{W}$ ) is quite a bit lower than current costs, which are in the $\$ 8-\$ 10$ per-watt range.

\footnotetext{
* Another 31 systems have been installed in LIPA's service territory; these systems were provided free of charge as part of a promotional lottery. However, these free systems would not be eligible for a tax credit.
} 
Outreach. Stakeholders acknowledged that the tax credit, like the state's other incentives, needs to be more widely promoted to increase its use. Unlike New York's Residential PV Program or the Energy $\$$ mart ${ }^{\mathrm{SM}}$ Loan Program, which are promoted by the program administrator and vendors with whom they partner, the tax credit-without an official outreach component to the program-is potentially less visible. According to the number of claims, however, the tax credit appears to be used more often than the buy-down programs, even though residents eligible for the tax credit are also eligible for the buy-down programs. Fortunately, the administrators of some other state incentive and outreach programs provide details on the tax credit. While NY Shines and LI Shines promote the incentives as a package, this same approach should be taken by other stakeholders, including dealers and installers.

Complementary Financial Incentives. In addition to the PV tax credit, New York offers a host of other incentives that encourage the installation of renewable energy systems. Buydowns offered by NYSERDA and the Long Island Power Authority, net-metering rules, NYSERDA's Energy \$mart ${ }^{\mathrm{SM}}$ Loan, and the property-tax exemption all make investing in renewables more attractive than a couple of years ago. The extent to which these incentives actually work in concert with the Residential PV program varies.

Buy-Downs. NYSERDA offers a $\$ 3 / \mathrm{W}$ buy-down for residential PV (via contracts with two PV distributors). LIPA offered a $\$ 6 / \mathrm{W}$ rebate until September 30, 2002, and currently stands at $\$ 5 / \mathrm{W}$. Based on program-participation data, it appears that participants in these programs also claim the tax credit.

Loan Program. Few program participants have taken advantage of the Energy $\$$ mart ${ }^{\mathrm{SM}}$ Loan program, despite a $4.5 \%$ buy-down of the market interest rate. Some stakeholders reported that customers were unable to find a participating bank that would lend to homeowners. The Residential PV Program administrator is considering developing a low-interest financing package in partnership with a single lending institution. To facilitate "one-stop shopping," homeowners would work directly with the PV installer to apply for the loan.

Net Metering. New York's net-metering law applies to residential PV systems of $10 \mathrm{~kW}$ or less and enhances the financial benefit offered by the buy-down and other incentives. However, difficulty securing interconnection agreements with utilities has prevented customers from realizing immediate benefits from the net-metering policy thus far.

Property-Tax Exemption. While the property-tax exemption-which is equal to the increase in assessed value attributable to a solar or wind energy system - clearly has some financial benefits for program participants, it was not promoted and most stakeholders were not aware of it. No information is made available to potential participants, and the information does not appear on the program Web site. Program participants often find out about the exemption after the fact. Potential consumers should be made aware of this additional financial incentive for inclusion in the overall economic analysis of a project.

Infrastructure. The primary policy factor limiting the number of residential installations, and consequently the use of the tax credit, is ostensibly the protracted and cumbersome interconnection approval process. While interviewees agreed that safety and quality must be assured, they contended that the technical requirements in New York are excessive relative to 
standards required in other states. The additional testing and administrative obstacles utilities place on installations have limited the program's impact on the market as a result. One installer reported that she curtailed her efforts in upstate New York as a result of the repeated conflicts with utilities and began to focus on the Long Island market instead. Observers noted that early adopters, too, have been discouraged by the experience and are likely sharing their story with other potential customers. Developing and implementing a simple and standardized utility interconnection process has been a serious challenge and will require cooperative efforts of utilities, the state's Department of Public Service, NYSERDA, and the PV industry.

Other Influences. Public concerns about energy security, a desire to reduce dependence on utilities, and high electricity costs are considered to be the primary external influences motivating consumers to purchase renewable energy technologies. However, stakeholders agreed that even with incentives, the economics of investing in renewable energy technologies still may not be considered attractive enough to stimulate more deployment in the residential sector. Financial barriers, together with the difficulties associated with interconnection, appear to limit investments in renewable energy technologies unless individuals are strongly motivated by noneconomic factors. NYSERDA's strategy to work with the residential builders to install PV in new construction can help ease the financial burden by allowing homeowners to incorporate the system into their home mortgage. 


\section{NORTH CAROLINA Renewable Energy Tax Credit}

\section{Summary of Findings}

North Carolina's tax credit has been in existence for more than two decades, yet no data exists to evaluate its impact with the exception of 2000 data. Extensive survey work would be required to ascertain program use information for past years. Stakeholders interviewed reported that individuals who install systems are motivated by environmental, reliability, or self-sufficiency concerns. Businesses that adopt solar technologies tend to be interested in making a statement about their commitment to sustainability or where certain technologies are economically feasible. Outreach, training, technical assistance, and demonstration efforts of the N.C. State University Solar Center have benefited thousands of individuals and hundreds of renewable energy and building professionals. However, infrastructure and awareness challenges abound: insufficient public understanding of the benefits and applications of renewable energy technologies; a weak distribution network; the absence of standardized and simple state interconnection and net-metering policies; difficulty securing funding for certain applications from private lenders; and inadequately educated inspectors. Furthermore, other financial incentives in the state are not well coordinated with one another - the property-tax credit, loan credit, and tax credit only work in concert for certain applications.

The tax-credit program's strengths include:

- a generous credit percentage and relatively high maximum incentive amount;

- the broad array of renewable energy technologies eligible for the credit; and

- the establishment of minimum equipment standards through additional program guidelines.

Limitations of the tax credit include:

- a minimal outreach component;

- participants can only offset up to $50 \%$ of their state tax liability with the renewables tax credit;

- the inability of government entities and nonprofit organizations to capitalize on the incentive;

- minimal installer qualification requirements;

- the absence of tax-credit data on installed systems, project costs, and energy savings achieved, which diminishes the ability to evaluate and improve program performance.

North Carolina offers a significant tax incentive, yet the absence of data makes it impossible to gauge its effectiveness. Although installers have indicated that solar water-heater sales are steady, and that a handful of PV systems are sold each year, it is unclear whether these purchasers can and do take advantage of the tax credit. It is clear from the experience of stakeholders interviewed, however, that additional complementary policies and incentives, infrastructure development, and a comprehensive marketing campaign would likely increase the adoption of renewable energy systems in the state, and thus more effectively leverage the financial benefit of the tax credit. 


\section{Program Overview}

Background. ${ }^{19}$ The North Carolina General Assembly originally passed solar-energy tax credits in 1977, spurred by the need to support indigenous energy sources as a result of the oil crises of the 1970s. A tax credit was established for the purchase and installation of active and passive solar hot water, and solar heating and cooling systems in any building in North Carolina.

Throughout the years, additional tax credits encouraging investment in renewable energy sources were enacted. These included credits for the installation and equipment costs of hydroelectric generators, solar energy equipment for the production of heat or electricity in manufacturing or service processes, wind energy devices, and ethanol facilities. These tax credits were statutorily provided in both the corporate and individual income tax laws and had different calculation methods and maximum credit amounts.

In 1999, the General Assembly repealed the 14 existing renewable energy tax credits in the corporate and individual income tax laws. Some of the repealed credits, which ranged from $10 \%$ to $40 \%$, were recodified into one $35 \%$ tax credit for investing in renewable energy property. The different kinds of technologies that qualify for the renewable energy credit are subject to the same tax-credit rate, but the ceilings that apply to renewable energy property serving nonresidential property are different than those that apply to renewable energy property serving residential property. The new tax credits became effective January 1, 2000.

Eligible Technologies. Most renewable energy technologies are eligible for North Carolina's 35\% tax credit. These include active and passive solar technologies (including daylighting), wind, biomass, and hydroelectric.

Eligible Applicants. Individual or corporate taxpayers in North Carolina are eligible for the tax credit.

Incentive Amount and Terms. Applicants can claim a 35\% tax credit for the cost of renewable energy property constructed, purchased, or leased by a taxpayer and placed into service in North Carolina during the taxable year. Costs eligible for the tax credit include the cost of the equipment and associated design, construction costs, and installation costs less any discounts, rebates, advertising, installation assistance credits, name referral allowances, or other similar reductions. The credit can be taken against franchise tax, income tax or, if the taxpayer is an insurance company, against the gross premiums tax.

If the property serves a single-family dwelling, the credit is taken for the taxable year in which the property is placed in service. The unused portion of the credit may be carried over for the next five succeeding years. For multifamily and commercial buildings, the credit is taken in five equal installments beginning with the year the property is placed in service. However, the allowable credit cannot exceed $50 \%$ of the taxpayer's tax liability for the year reduced by the sum of all other credits.

The credit is subject to various ceilings depending on whether the renewable energy equipment serves nonresidential property or residential property and, for residential property, 
the kind of renewable energy technology being used. For nonresidential property, the credit ceiling is $\$ 250,000$ per installation. For residential property, the ceilings are:

- $\quad \$ 1,400$ per dwelling unit for solar energy equipment for domestic water heating;

- $\$ 3,500$ per dwelling unit for solar energy equipment for active space heating; combined active space and domestic hot-water systems, and passive space heating; and

- $\$ 10,500$ per installation for any other renewable energy property for residential use.

Application Process. The allowable credit is calculated on North Carolina's Department of Revenue Form NC-478G, and the amount eligible to be claimed as a credit for the current year is carried to Form NC-478. Form NC-478 is used to determine if the credit is reduced because it exceeds the $50 \%$ of tax, less other credits limitation; and for corporations to elect whether the credit is to be claimed against franchise tax or income tax. These forms are submitted along with the main income-tax form.

Outreach Activities. North Carolinians can access information about the tax credit through the Web sites of the NCSU Solar Center, the North Carolina Sustainable Energy Association, and some installers. The NCSU Solar Center emphasizes the availability of the tax credit through workshops and presentations, including those conducted in conjunction with Million Solar Roofs communities. The center also responds to information requests regarding taxcredit eligibility and the application process. The state's Department of Revenue Web site makes claim forms available online. However, there is no aggressive marketing of the tax credit, and stakeholders agreed that most people are unaware of the opportunity. Two installers interviewed admitted that the renewable energy industry has not done an adequate job marketing the availability of the tax credit and the benefits of using renewable energy resources in general.

\section{Program Results}

Table 6 below shows the only available data from more than two decades of tax-credit availability. This lack of data severely limits any evaluation of the overall impact of the incentive. Prior to the revised tax-credit legislation in 2000, the state's Department of Revenue had no requirement to report results, and thus did not track claims. A more detailed survey of the state's renewables community would be required in order to get a more accurate estimate of the number of systems installed in the state and use of the tax credit.

Table 6: North Carolina Renewable Energy Tax-Credit Program Results

\begin{tabular}{|c|c|c|c|c|}
\hline Year & \# of Claims & $\begin{array}{c}\text { Total Credit } \\
\text { Amount }\end{array}$ & $\begin{array}{c}\text { Average } \\
\text { Claim }\end{array}$ & $\begin{array}{c}\text { Total } \\
\text { Project Cost }\end{array}$ \\
\hline 2000 & 50 & $\$ 53,261$ & $\$ 1,065$ & $\$ 1,061,822$ \\
\hline
\end{tabular}

According to the N.C. Department of Revenue, approximately $90 \%$ of the credits were claimed by individuals, and only a handful by corporate entities. Because the number of corporate tax credits was so small, the exact number could not be released because the information might allow a particular corporate taxpayer to be identified. 


\section{Observations and Lessons Learned}

North Carolina's tax credit has been in existence for more than two decades, yet no data exists to evaluate its impact with the exception of 2000 data. Extensive survey work would be required to ascertain program-use information for past years. The key factors influencing the effectiveness of North Carolina's tax credit are discussed below in terms of program design and implementation, availability of complementary financial incentives, infrastructure issues, and other influences.

Program Design and Implementation. Program features considered to influence the effectiveness of the program are the incentive amount and restrictive terms, eligible applicants, quality-assurance provisions, and outreach efforts. These are discussed below.

Incentive Amount and Terms. North Carolina's decision to consolidate more than a dozen renewable tax credits into a single, catchall credit has greatly simplified the incentive process for all parties involved. Moreover, the $35 \%$ credit, with high maximum incentive amounts relative to other states, is the most generous in the country. Most tax credits offered by other states do not apply to such a wide variety of renewable energy technologies. North Carolina's tax credit is scheduled to expire in 2006.

There are some provisions of the tax credit, however, which are considered to limit its effectiveness for larger, more costly systems such as photovoltaics, wind, and hydroelectric facilities. For example, the allowable credit, together with any other tax credits, cannot exceed $50 \%$ of the taxpayer's tax liability for the year. Individuals who do not have a high tax liability are only able to take advantage of a small portion of this credit during the year of installation. Although individuals may carry over the remaining credit amount for up to five years, having to spread the incentive over multiple years reduces the overall benefit of the incentive. Eligible nonresidential taxpayers must take the credit over a five-year period. Some stakeholders suggested that a more immediate incentive would improve the effectiveness of the program and offer a better tool for marketing renewables, in general, and the tax credit in particular.

Eligibility. State and local government agencies, schools, and other public or nonprofit organizations that do not have state tax liabilities cannot take advantage of this incentive. This is particularly problematic because these entities are often considered early adopters of renewable energy technology and could establish demonstration sites if this incentive were advantageous to them.

Quality Assurance. With respect to photovoltaic systems, one installer criticized a state requirement that equipment be installed by licensed electricians, arguing that electricians are not necessarily properly qualified to install PV systems correctly. Rather, a solar-specific license - as required in Florida and California - would be more valuable to ensure proper installation. Likewise, two solar installers opined that building inspectors are overburdened and inadequately trained to inspect solar installations. These installers expressed a strong belief that inspectors should be properly trained and educated, as well as sufficient in number and availability. 
Outreach. All subjects interviewed agreed that public awareness of North Carolina's tax credit is inadequate, primarily due to weak or nonexistent publicity and marketing efforts. One installer in the western part of the state acknowledged that most of his customers were not aware of North Carolina's tax credit when they initially pursued a project. Rather, the credit was almost invariably serendipitous. Other installers interviewed noted that at least some customers are aware of the incentive.

The NCSU Solar Center, the N.C. Sustainable Energy Association, and the Million Solar Roofs Initiative Program have been somewhat active in marketing the credit, and some installers use the tax credit as a sales tool. However, the NCSU Solar Center provides technical assistance regarding the tax credit but does not conduct marketing activities specifically for the tax credit. One environmental spokesman suggested that the state's energy office and various in-state, nonprofit environmental organizations should spearhead publicity and marketing campaigns. Furthermore, in addition to the tax credit itself, renewable energy in general must be publicized through increased and intensified marketing, education, demonstration, and outreach efforts.

Alternative Approaches. One alternative to North Carolina's existing tax credit is a production tax credit, suggested by industry and environmental advocates. However, there is insufficient model legislation for such an incentive; lawmakers would therefore need to be adequately educated in this arena. Another preferred alternative to the tax credit is a buydown, although such an incentive may not be politically feasible. Regardless, in order to promote their adoption, renewable energy advocates suggested that incentives should have as long a life span as possible.

Complementary Financial Incentives. North Carolina offers a property-tax exemption for solar equipment and a low-interest renewable energy loan for commercial, public, and nonprofit facilities. However, these incentives work in concert with the tax credit only for solar heating and cooling technologies installed on certain types of buildings. The absence of a statewide net metering is viewed as a significant barrier to adoption to renewable energy technologies. One installer suggested that the lack of a sales-tax exemption, available in 12 other states, may motivate some customers to purchase equipment over the Internet as a way to avoid paying sales tax, thus depriving sales by local businesses.

Property-Tax Exemption. This exemption mandates that active solar heating and cooling systems should not be assessed at more than the value of a conventional heating or cooling system for the purposes of property taxation. The exemption applies only to active solar systems and does not include any land or structural elements of buildings such as walls and roofs. Residential, commercial, and industrial facilities are eligible for this incentive. The exemption does not include solar electric (PV) and other renewable energy technologies that are eligible for the tax credit, despite the fact that some of these technologies may add significantly more value to property than solar heating and cooling systems.

Low-Interest Loan. In January 2002, the state initiated a low-interest loan program for energy-improvement projects, including renewable energy systems. The Energy Improvement Loan Program is available to North Carolina businesses, local governments, and nonprofit organizations (including public schools) that seek to improve energy 
efficiency, incorporate renewable energy resources, or otherwise reduce energy costs or demand. Note that residents are not eligible for this incentive.

Although these incentives complement the tax-credit technologies by reducing up-front costs and eliminating the possibility of increased property taxes, they are not fully coordinated. The property-tax exemption and loan program are only available for some building sectors and technologies, and do not match the eligibility for the tax credit. A coordinated package of incentives would likely be more effective in stimulating the renewables market.

Net Metering. North Carolina is one of only 14 states without net metering. Stakeholders interviewed consider the lack of a statewide net metering law to be a major barrier to the adoption of renewable energy technologies. Clearly, the prospect of lowering one's electric bill by feeding excess power back to the grid is economically enticing. One installer noted that net metering would open up a significant market for renewable energy systems; his prediction is based on comments from potential customers who are waiting for the approval of net-metering legislation before installing systems.

Infrastructure Issues. Most stakeholders firmly believe that the state's weak renewable energy-equipment infrastructure is a major impediment to renewable energy technology adoption. Barriers include a weak distribution network, inadequate coordination and outreach to financial institutions and local inspectors, and the lack of a simple and standardized utility interconnection process.

Dealer Network. Dealer networks and system integrators are just developing in North Carolina, so until the past year or so, the ordering, delivery, and assembly processes had been tedious, time-consuming, and expensive. One solar-thermal installer complained that he is forced to order equipment from at least four other states. Ideally, local access to integrated systems and local warehouses offering renewable energy equipment would be available. Two new solar-thermal and daylighting manufacturer/distributors have begun to serve the commercial and residential market and have coordinated workshops and training for dealers and installers. These activities, in coordination with the work of the North Carolina Solar Center and the Million Solar Roofs partnerships described on the following page, are expected to help boost the solar market in the state.

Financing. Bank financing also has been a stumbling block to the purchase of renewable energy technologies, according to one installer interviewed. Some customers complain that banks refuse to incorporate the cost of solar-electric systems into mortgages for new home construction. In addition, banks are extremely reluctant to offer mortgages to new, off-grid homes - effectively cornering some residents into being less than forthcoming on mortgage applications. It is critical to encourage in-state lending institutions to recognize PV as a safe, reliable, important, and stable source of electricity. Furthermore, multiple interviewees expressed frustration at the absence of energy-efficient mortgage lenders in the areas of North Carolina they serve. Banks should be made aware of the value of energy efficiency and renewable energy.

Local Inspectors. Building codes and neighborhood association regulations also are influential. Stringent building codes and rules devised by neighborhood associations often prevent the installation of renewable energy systems. Renewable energy advocates should 
cooperate with these entities — and with inspectors - when possible, and consider their insight and recommendations. Such cooperation and input would be especially beneficial for outreach purposes, as well as for encouraging legislation that would ultimately affect all parties.

Million Solar Roofs. North Carolina is a partner in the Million Solar Roofs Initiative and directs activities in five MSRI communities-Durham, Chapel Hill, Asheville (and four surrounding counties), Wautaga County, and Guilford County. North Carolina's MSRI "core approach" centers around building demand for solar products, and the infrastructure to serve them, in local communities throughout the state. To achieve these ends, these communities, with the assistance of the NCSU Solar Center, sponsor training workshops and consumereducation activities. As a second priority, North Carolina's MSRI partners seek to enlist the support of key stakeholder groups at the state level, and to reduce or eliminate the barriers to solar development, such as the lack of net metering, or building code issues. This program is gaining momentum and plays a critical role in informing these communities about the taxcredit availability.

Interconnection. North Carolina's interconnection standards are both strict and complex. Several interviewees stated that simplified interconnection standards would encourage renewable energy-system installments. Eliminating the need for battery backup reduces costs and maintenance associated with storing excess electricity. A burdensome interconnection process - compounded with the inability to net meter-increases costs to consumers, thereby reducing the effectiveness of the tax credit and discouraging individuals and businesses from installing systems.

Other Influences. Attitude and philosophy play a major role in the decision to invest in renewable energy systems. Some stakeholders interviewed suggested that solar and other renewable energy sources finally seem to be overcoming the negative public perception that has cloaked the industry since the 1970s. This poor public image, spawned by faulty equipment, shoddy installations, inappropriate incentives, and a surfeit of shady, inexperienced dealers, has haunted renewable energy advocates for more than two decades. Yet confidence is cautiously being restored.

Still, stakeholders agreed that a systematic and comprehensive marketing campaign is necessary to raise the awareness of renewable technologies and mold the attitudes of the general public accordingly. The renewable energy industry cannot rely on pitching the costeffectiveness of renewable technologies. Therefore, a marketing and awareness campaign should be educational - touting the environmental gains, self-sufficiency, and potential financial benefits (and incentives) of renewable energy systems. 


\section{Summary of Findings}

Nearly 6,000 Oregon businesses have benefited from the Business Energy Tax Credit (BETC) during the past two decades, with energy-conservation projects dominating the list of claims. Of the $500+$ renewable energy projects, about half were for larger-scale systemsbiomass and hydroelectric - and half for on-site energy use - solar and geothermal. Given the program's longevity and coordination with other energy programs, there is a relatively high degree of awareness of the incentive. Observers noted that despite the small fraction of businesses investing in renewables, the tax credit has played an important role in the development of these projects. Some of these companies also take advantage of the state's low-interest loan for renewables. The property-tax exemption enhances the benefit of the tax credit, but it is unclear how many businesses are aware of its existence. Potential barriers to the deployment of renewable energy technologies, in general, include inconsistent implementation of interconnection and net-metering policies, uncertainties associated with the state's newly restructured electric utility industry, and relatively high equipment costs.

Strengths of the BETC program include:

- administration by the state's energy office, which coordinates the program with other energy initiatives, and leverages partnerships with other organizations to promote it;

- certification of projects as eligible for the tax credit prior to installation;

- the eligibility of a wide variety of technologies;

- the ability of applicants to bundle energy efficiency improvements with installation of renewable energy technologies; and

- a heightened ability to evaluate and improve the program based on the program's tracking of details on technologies, project costs, and energy savings.

Limitations of the BETC program include:

- fees charged to apply for a certification to receive a tax credit.

Program administrators anticipate that the newly expanded pass-through option will stimulate increased investment in renewables by government agencies, schools, and nonprofit organizations. Furthermore, the state's recently established public-benefits fund presents additional opportunities to create a more comprehensive and coordinated strategy to develop markets for a variety of renewable energy technologies. 


\section{Program Overview}

Background. The Oregon legislature created the Business Energy Tax Credit (BETC) in 1979. Administered by the Oregon Office of Energy (OROE), the BETC encourages investment in energy conservation, recycling, renewable energy, alternative transportation fuels, and sustainable buildings. Approximately 11 staff members spend a portion of their time on the program, the equivalent of almost four full-time employees.

The administrative costs of the BETC are funded through a user fee. This user fee is a review charge levied for each application submitted. The review charge is $0.75 \%$ of the eligible project cost, with the minimum charge per application being $\$ 30$. In 2001, $\$ 850,000$ was generated from user fees.

Eligible Technologies. Renewable-resource technologies eligible for BETC include solar, wind, biomass, hydro, and geothermal electric. The tax credit also is available for energy conservation, weatherizing, recycling, less-polluting transportation fuels, and sustainable buildings.

Eligible Applicants. Tax credits are available to any Oregon business, including trade organizations or rental property owners who pay taxes for a business site in Oregon. The credit is available to the business, its partners, or its shareholders.

A recent program modification - and unique feature - is the "pass-through option," which allows nontaxed entities such as schools, government agencies, and nonprofit organizations to purchase systems and transfer the credit to a third party, such as a large commercial or industrial company in the community or an energy-services company, in exchange for the net present value of the tax credit. Businesses with a tax liability also may choose to use the pass-through option. Prior to the October 2001 tax changes, the pass-through option was available only through the utilities and was used mainly for transportation fuel projects.

The net present value is determined each year by the OROE in consultation with economic advisers and tax accountants. For the year 2002, the rate is $27 \%$-if the credit is taken over five years (projects with eligible costs of more than $\$ 20,000$ ) or $33.5 \%$ if taken over one year (those with eligible costs of $\$ 20,000$ or less). This option is designed to broaden eligibility requirements and expand the market for renewables and energy efficiency. However, because the option is new, no data is available on the use of this option.

Incentive Amount and Terms. The tax credit is 35\% of eligible project costs. Eligible costs include the incremental cost of the system or equipment beyond standard practice. If the credit amount is $\$ 20,000$ or less, it may be taken during the first year. The credit is generally taken over five years: $10 \%$ in the first and second years and $5 \%$ each year thereafter. If necessary, the unused credit can be carried over for up to eight years. The maximum credit allowed is $\$ 10,000,000$ per project. A project must replace at least $10 \%$ of the electricity, gas or oil that would otherwise be used. Lighting projects must provide a $25 \%$ savings. Financial incentives (such as rebates) provided by utilities are no longer deducted from the eligible project cost when calculating the tax-credit amount. 
Application Process. The BETC application process has two stages - a preliminary certification stage and a final certification stage. First, an Application for Preliminary Certification and a project-specific Supplementary Information form must be submitted to the Oregon Office of Energy at least 90 days prior to the project start date. Once approved, a Preliminary Certificate is provided to the applicant. Construction of the project may begin at this time. If project changes occur, an Amended Preliminary Certificate must be submitted and approved. A Final Certification Application must be filed on completion of the project. The Final Certificate will indicate the amount of the tax credit, which is then claimed on the business' state income-tax form. This process offers assurance to project owners that their investments will qualify for the credit and, at the same time, serves as a quality-control mechanism to ensure that projects are technically sound.

For complex projects, the OROE recommends that applicants schedule a preapplication meeting with them prior to submitting a BETC application. By discussing customers' energy project ideas early in the development of the project, the staff is able to suggest energysaving ideas and technologies, as well as other types of assistance that the agency can provide.

Outreach Activities. The OROE promotes the BETC and other programs through its Web site, workshops, conferences, information provided to utilities, and advertising through journals and radio. Target audiences have included the League of Counties and Cities, schools, American Institute of Architects, energy-saving performance contractors, rural farmers, and utilities. The BETC program Web site includes detailed program and contact information, including a tax-credit brochure, a Q\&A fact sheet, and applications. Renewable energy vendors and installers reported using the program as a marketing tool to promote their services.

\section{Program Results}

Oregon businesses received 5,827 energy tax credits from 1981 to 2001, as shown in Table 7 . Conservation projects received the majority of the tax credits, accounting for about twothirds of credits issued. Conservation projects included more than 1,400 rental weatherization projects for more than 45,000 units. Approximately $10 \%$ of the tax credits were issued for renewable energy projects. Renewable energy projects consisted of approximately $40 \%$ biomass, $40 \%$ solar, $10 \%$ geothermal, $5 \%$ hydroelectric, and less than $2 \%$ wind.

On average, approximately 280 businesses receive tax credits each year, with approximately 25 of these annual tax credits allocated for renewable energy projects. Energy savings and generation equal about $\$ 100$ million a year. ${ }^{20}$ 
Table 7: Oregon Business Energy Tax-Credit Program Results*

\begin{tabular}{|l|c|c|c|}
\hline \multicolumn{1}{|c|}{ Technology } & $\begin{array}{c}\# \text { of } \\
\text { Certifications }\end{array}$ & Project Costs & $\begin{array}{c}\text { Energy Saved or } \\
\text { Produced } \\
\text { Million BTU) }\end{array}$ \\
\hline Biomass & 207 & $\$ 45,309,546$ & $\$ 3,046,339$ \\
\hline Co-Generation & 7 & $\$ 22,942,883$ & $\$ 747,613$ \\
\hline Conservation & 3,903 & $\$ 287,306,297$ & $\$ 7,561,315$ \\
\hline Geothermal & 56 & $\$ 6,503,303$ & $\$ 72,939$ \\
\hline Hydro & 24 & $\$ 25,757,818$ & $\$ 196,356$ \\
\hline RD\&D & 1 & $\$ 99,788$ & $\$ 9,818$ \\
\hline Recycling & 984 & $\$ 63,129,753$ & $\$ 123,410$ \\
\hline Solar & 205 & $\$ 4,275,136$ & $\$ 39,931$ \\
\hline Transportation & 125 & $\$ 9,111,005$ & $\$ 341,181$ \\
\hline Waste Heat Recovery & 306 & $\$ 26,869,424$ & $\$ 3,141,984$ \\
\hline Wind** & 9 & $\$ 2,860,552$ & $\$ 13,413$ \\
\hline \hline \multicolumn{1}{|c|}{ Total } & $\mathbf{5 , 8 2 7}$ & $\mathbf{\$ 4 9 4 , 1 6 5 , 5 0 5}$ & $\mathbf{\$ 1 5 , 2 9 4 , 2 9 9}$ \\
\hline
\end{tabular}

* 1981 - 2001 Preliminary data as of 5/21/02 from Oregon Office of Energy

** Wind installations are no longer in operation

\section{Observations and Lessons Learned}

Nearly 6,000 Oregon businesses have benefited from the Business Energy Tax Credit (BETC) during the past two decades, with energy-conservation projects dominating the list of claims. Of the 500+ renewable energy projects, about half were for larger-scale systemsbiomass and hydroelectric - and half for on-site energy use - solar and geothermal. Oregon's progressive, environmentally conscious culture is credited with the adoption of solar-energy technology despite unfavorable solar resources. Observers noted that despite the small fraction of businesses investing in renewables, the tax credit has played an important role in the development of these projects. Given the program's longevity and coordination with other energy programs, there is a relatively high degree of awareness of the incentive. The key factors influencing the effectiveness of the tax credit are discussed below in terms of program design and implementation, availability of complementary financial incentives, infrastructure issues, public attitudes and awareness, and other influences.

Program Design and Implementation. Program design and implementation features that contribute to the effectiveness of the program include the variety of eligible technologies, the program administrator's responsiveness to client needs, and the cultivation of partnerships to promote the program.

Eligible Technologies. The wide variety of eligible renewable energy and energy efficiency technologies for the building and transportation sector make the tax credit a versatile incentive for the Oregon businesses. Based on the needs of the marketplace, the Energy Office has made a number of changes to BETC during its 23-year history, including the addition of technologies eligible for the incentive. Some applicants bundle energy efficiency measures and renewable energy technologies. 
Application Process. Oregon's Office of Energy receives a large volume of tax-credit applications each year. A program this broad in scope stretches the staff and the administrative budget in order to process all the applications in an efficient and timely manner. However, stakeholders reported that the agency is consistently responsive and timely in its service to the public. OROE has streamlined their programs to make it easier for businesses to participate, with significant efficiency improvements coming in the form of Web-accessible program information and downloadable applications. This improvement alone has saved more than $\$ 18,000$ per year in postage.

Outreach. Partnerships have played a critical role in educating potential participants in Oregon's energy programs. Partnerships that have been valuable to the BETC program include those with renewable energy and conservation equipment vendors and installers, utilities, and engineering and architectural firms. Stakeholders explained that these partners help to spread the word about the BETC and other renewable energy incentives in the state. In addition, the OROE has a close relationship with other state agencies and advocacy groups within the state and region.

Complementary Financial Incentives. Oregon offers several complementary financial incentives that potentially enhance the effectiveness of the tax credit. However, only a small fraction of project owners have used the state's Small-Scale Energy Loan (see case study on page 101). Observers also noted that there is little awareness of the property-tax exemption for renewable energy property. And, despite the existence of a net-metering law, its inconsistent implementation is problematic and may discourage investment.

Low-Interest Loan Program. The SELP provides loans to residents and businesses for the purchase of energy efficiency and renewable energy technologies. Oregon businesses can use both the SELP and the BETC to maximize their financing of renewable energy technologies. The Office of Energy reported that a majority of SELP loan recipients also apply for a state tax credit. By providing information about the tax credit on the SELP application, the agency is encouraging borrowers to investigate their eligibility for a tax credit.

Property-Tax Exemption. Oregon offers a property-tax exemption, whereby the value of renewable energy equipment is exempt from state property taxes. Like the tax credit and loan programs, a variety of technologies are eligible — solar, geothermal, wind, hydro, fuel cells, and methane gas. This exemption can be a valuable incentive for larger-scale projects and should be promoted on a larger scale.

Net Metering. Oregon's net-metering law applies to customers with solar, wind, or hydropower systems of up to $25 \mathrm{~kW}$, although enrollment is limited to a total installed capacity of $0.5 \%$ of the utility's historical single-hour peak load. Stakeholders reported that the ease with which customers can establish net-metering agreements varies among utilities, and that the utilities are still climbing the knowledge curve in this area.

Infrastructure Issues. Factors external to the program that may be limiting its use include the inconsistent implementation of interconnection and net-metering policies throughout the state and the uncertainty resulting from the electric utility restructuring process. New contractor licensing requirements are expected to enhance program effectiveness for solar installations. 
Electric Utility Restructuring. Partial deregulation of Oregon's retail electricity market began in 2002. Beginning in March 2002, Oregon's two largest utilities, Portland General Electric and PacifiCorp, are required to allow their nonresidential customers to choose their electricity provider. Residential customers of these two utilities may choose from three rate options, one of which is a renewable resources rate. The state's other electricity providers have the option to participate in deregulation. Some observers suggested that uncertainty about the impact of restructuring may deter businesses from investing in renewables.

Installer Licensing. Stakeholders interviewed anticipate that the new contractor-licensing requirements will enhance program effectiveness by improving quality of solar hot water and photovoltaic systems, and boosting consumer confidence in the industry. State contractorlicensing requirements are in the process of being developed. During the 2001 legislature, a law was passed requiring the licensing of all installers of solar hot water and photovoltaic systems. The Building Codes Division of the state has issued interim licensing rules while the final rules are being completed.

Other Influences. Other influences that impact the use of BETC include the prevalence of pro-renewable energy attitudes in the state and the relatively high cost of renewables. Progressive attitudes toward environmental and energy-conservation issues, together with an array of supportive renewable energy policies, have helped the state become one of the nation's leaders in solar installations. Policies encouraging renewables have been implemented despite the state's historically low electricity prices. Stakeholders reported that $\mathrm{Y} 2 \mathrm{~K}$ and recent price spikes in electricity costs have increased interest in renewable and energy-efficient technologies during the past few years in particular. Some observers noted a strong sense of "isolationist thinking" among some of the state's residents and a desire to live in close connection to the land. Oregon has a high level of activism among its renewable energy community, and there are a number of nonprofit organizations whose missions include the promotion of renewable energy. Oregon became the first state in the country to install photovoltaics on its capitol building in April 2002. Despite financial incentives and favorable attitudes, observers acknowledged that equipment costs are still a barrier to more widespread installation of renewable energy technologies by the commercial sector. 


\section{Summary of Findings}

More than 20,000 renewable energy system owners have received tax credits under the Residential Energy Tax Credit (RETC) Program during the past 25 years, with solar water heaters accounting for more than $80 \%$ of these claims. Stakeholders interviewed considered the tax credit to be a critical tool for the development of the residential renewable energy market (solar in particular), and they noted that there is a relatively high degree of awareness of the incentive. Oregon's progressive, environmentally conscious culture is credited with the adoption of solar-energy technology despite modest solar resources. Complementary financial incentives, particularly utility incentives, net metering, and a property-tax exemption, strengthen the effect of the tax credit in some circumstances. Factors that discourage the adoption of renewable energy technologies, and limit participation in the program as a result, are high equipment costs and inconsistent net-metering specifications within the state.

Strengths of the RETC program include:

- administration by the state's energy office, which coordinates the program with other energy initiatives and leverages partnerships with other organizations to promote it;

- partnerships with installers to certify tax-credit eligibility and assist with the application process;

- a performance-based mechanism of the tax credit;

- the eligibility of a wide variety of technologies;

- the ability of applicants to bundle energy efficiency improvements with installation of renewable energy technologies; and

- a heightened ability to evaluate and improve the program based on the program's tracking of details on technologies, project costs, and energy savings.

Limitations include:

- a low maximum incentive amount $(\$ 1,500)$ for PV;

- the uncertainty of continued program funding, despite program longevity.

The recently established public-benefits fund in Oregon presents additional opportunities to create a more comprehensive and coordinated strategy to develop markets for a variety of renewable energy technologies. 


\section{Program Overview}

Background. The Oregon legislature created the Residential Energy Tax Credit in 1977, and the program became effective beginning in tax year 1978. Administered by the Oregon Office of Energy (OROE), the tax credit encourages the use of renewable resources and energy-efficient appliances to meet home energy needs. The equivalent of four full-time employees administers the program. The RETC is funded through a State Energy Plan (SEP) block grant from the U.S. Department of Energy. No program fees are charged to program participants. Although the tax credit originally was created for renewable energy projects, the legislature gradually has expanded the tax credit to include other technologies. In 1997, energy-efficient household appliances were added; and, in 1999, fuel cells were added.

Eligible Technologies. Renewable resources eligible for the tax credit include solar; wind; renewable fuel vehicles; and charging/refueling, geothermal electric, and fuel cells. Other eligible technologies include energy-efficient appliances, duct systems, heat pumps, condensing furnaces, and boilers.

Eligible Applicants. Tax credits are available to any Oregon homeowner or renter. The home or vehicle must be located or registered in Oregon.

Incentive Amount and Terms. The tax-credit amount varies by project. The maximum tax credit amount is $\$ 1,500$. See Table 8 for a listing of eligible technologies and associated taxcredit amounts.

Application Process. To apply for the tax credit, a homeowner must complete and sign a tax-credit application and attach proof of payment and send it to the OROE. The agency will send back a "Certification" containing the tax-credit amount, usually within four to six weeks. Applicants claim the tax credit when they file their income-tax returns. Forms and instructions for completing the residential energy tax-credit application are available from the OROE, dealers, and contractors.

Contractors who have been certified by the OROE to complete the tax-credit paperwork can issue the tax-credit certificate directly to the homeowner at installation of the system. Certification in this context does not guarantee or in any way assure the quality of the work done by the contractor. The OROE offers two workshops annually to certify contractors. During these workshops, contractors learn how to complete the appropriate forms, leaving these workshops armed with forms to be distributed to customers. Certifying contractors helps the agency administratively by allowing the contractors to assist in filling out and overseeing the tax-credit paperwork. This mechanism allows the consumer to receive the taxcredit certification immediately at installation, providing assurance for the homeowner that the project will be eligible for the credit. This helps the installer because the tax-credit "Certification" might seal the deal. Contractors who are not on the approved list still may install systems that are eligible for the tax credit, but they are not authorized to complete the paperwork or issue the tax-credit certificate. 
Table 8: Oregon Residential Energy Tax-Credit Amounts by Technology ${ }^{21}$

\begin{tabular}{|l|l|}
\hline \multicolumn{1}{|c|}{ Technology } & \multicolumn{1}{c|}{ Amount } \\
\hline Hybrid and Alternative Fuel Vehicles & $\begin{array}{l}\$ 750 \text { for the purchase of a vehicle; } 25 \% \text { of conversion } \\
\text { cost, up to } \$ 750 ; 25 \% \text { of cost, up to } \$ 750 \text { for a } \\
\text { charging or refueling system }\end{array}$ \\
\hline Appliances & $\begin{array}{l}\text { Amount listed or } 25 \% \text { of net purchase price, } \\
\text { whichever is less }\end{array}$ \\
\hline Duct Systems & $25 \%$ of cost of sealing existing ductwork, up to $\$ 250$ \\
\hline Air-source Heat Pump Systems & $\$ 300-\$ 500$ \\
\hline Condensing Furnaces and Boilers & $\$ 225-\$ 350$ \\
\hline $\begin{array}{l}\text { Duct Systems for air-source heat } \\
\text { pumps and condensing furnaces and } \\
\text { boilers }\end{array}$ & $\$ 150$ \\
\hline $\begin{array}{l}\text { Testing and Servicing Heat Pumps } \\
\text { and AC }\end{array}$ & $25 \%$ tax credit, up to $\$ 250$ \\
\hline Photovoltaics & $\$ 3 / \mathrm{W}$ up to $\$ 1,500$ \\
\hline Solar Water Heating & $\begin{array}{l}\$ 0.60 / \mathrm{kWh} \text { saved in first year, up to } \$ 1,500 ; \\
\$ 0.15 / \mathrm{kWh} \text { for pools or spas }\end{array}$ \\
\hline Solar Space Heating & $\$ 0.60 / \mathrm{kWh}$ saved in first year, up to $\$ 1,500$ \\
\hline Wind Systems & $\$ 0.60 / \mathrm{kWh}$ saved in first year, up to $\$ 1,500$ \\
\hline Geothermal Energy & $\$ 0.60 / \mathrm{kWh}$ saved in first year, up to $\$ 1,500$ \\
\hline Fuel Cells & $\$ 0.60 / \mathrm{kWh}$ saved in first year, up to $\$ 1,500$ \\
\hline
\end{tabular}

Outreach Activities. Oregon's Office of Energy promotes the RETC and other programs on its Web site, and in workshops, conferences, information provided to utilities, and advertising through journals and radio. Target audiences have been homeowners, energy-saving performance contractors, vendors, and utilities. The RETC program Web site includes detailed program and contact information, including a residential energy tax-credit brochure, applications and instructions, lists of qualified contractors, and final program rules.

\section{Program Results}

More than 84,000 residential energy tax credits were awarded from 1978 to 2001, primarily for energy-efficient appliances. More than 20,000 of these tax credits have been for renewable energy technologies. In 2000 alone, the energy savings generated by all of the technologies was the equivalent of 53.4 million $\mathrm{kWh}, 889,000$ therms of natural gas, and 11,000 gallons of oil. ${ }^{22}$ Table 9 provides program results for projects implemented under the Residential Energy Tax Credit program. 
Table 9: Oregon Residential Tax-Credit Program Results*

\begin{tabular}{|c|c|c|c|c|}
\hline Technology & \# of Certs. & $\begin{array}{c}\text { Average Cert. } \\
\text { Amount }\end{array}$ & Total Certs & $\begin{array}{c}\text { Cumulative } \\
\text { Project Costs }\end{array}$ \\
\hline Hydro & 20 & $\$ 973$ & $\$ 19,457$ & $\$ 121,605$ \\
\hline Solar Water Heat & 17,074 & $\$ 1,057$ & $\$ 18,046,531$ & $\$ 58,909,685$ \\
\hline Solar Space Heat & 1,639 & $\$ 889$ & $\$ 1,456,929$ & $\$ 10,910,491$ \\
\hline Photovoltaic & 225 & $\$ 1,231$ & $\$ 276,963$ & $\$ 2,066,640$ \\
\hline Ground Source HP & 300 & $\$ 420$ & $\$ 126,049$ & $\$ 1,044,691$ \\
\hline Geothermal & 1,842 & $\$ 1,315$ & $\$ 2,422,881$ & $\$ 16,747,396$ \\
\hline Wind & 32 & $\$ 802$ & $\$ 25,648$ & $\$ 185,879$ \\
\hline Alt. Fuel Vehicles & 68 & $\$ 1,396$ & $\$ 94,928$ & $\$ 1,289,484$ \\
\hline \hline Renewables Total & $\mathbf{2 0 , 9 0 0}$ & $\mathbf{\$ 7 , 6 6 3}$ & $\mathbf{\$ 2 2 , 3 4 3 , 3 3 7}$ & $\mathbf{\$ 9 0 , 2 3 1 , 1 1 8 0}$ \\
\hline \hline Appliances & 63,182 & $\$ 146$ & $\$ 9,254,543$ & $\$ 53,630,766$ \\
\hline \hline Total & $\mathbf{8 4 , 0 8 2}$ & $\mathbf{\$ 3 7 6}$ & $\mathbf{\$ 3 1 , 5 9 7 , 8 8 0}$ & $\mathbf{\$ 1 4 3 , 8 6 1 , 9 4 6}$ \\
\hline \hline
\end{tabular}

Of the renewable energy projects, approximately $82 \%$ of the tax credits were issued for solar hot water-heating systems. Approximately $9 \%$ and $8 \%$, respectively, were issued for geothermal systems and solar space heating. The remaining $1 \%$ of tax credits represented hydroelectric projects, photovoltaics, wind, and alternative-fuel vehicles. Stakeholders reported that many of the solar projects would not have gone forward without the tax credit.

Tax-credit records show a steady increase in the number of residential solar systems installed during the past five years. Installations of PV, solar pool heating, and solar water-heating systems have been on the rise every year since 1997, with the exception of 2000, which saw a decrease in installations for all solar technologies except PV.

\section{Observations and Lessons Learned}

More than 20,000 residential renewable energy system owners have benefited from the Residential Energy Tax Credit Program during the past 25 years, with solar water heaters accounting for more than $80 \%$ of these claims. Stakeholders interviewed considered the tax credit to be a critical tool for the development of residential renewable energy market, and they noted that there is a relatively high degree of awareness of the incentive. The key factors influencing the effectiveness of the tax credit are discussed below in terms of program design and implementation, availability of complementary financial incentives, infrastructure issues, and other influences.

Program Design and Implementation. Program features considered to enhance the program's effectiveness include the streamlined application process, certified contractors who can issue tax-credit certificates to residents, partnerships with other stakeholder groups to promote the program, and the performance-based construct of the credit. Program elements that may limit participation include low maximum incentive amounts, which may not serve as a strong inducement to invest in higher cost technologies such as PV and wind. And despite the program's longevity, funding duration is uncertain and could be eliminated.

\footnotetext{
* This table represents the Oregon Office of Energy's preliminary estimate of 1978-2001 data, May 22, 2002.
} 
Application Process. The strong relationship that the OROE has with local contractors contributes to the overall effectiveness of the tax-credit program by facilitating the application process. Homeowners appreciate the efficient process and gain assurance that their projects qualify for tax credits.

Furthermore, the tax credit program continues to be simplified and made more accessible for the consumer. The OROE offers detailed program information on its Web site, including program applications and a list of certified contractors. This change alone is saving more than $\$ 18,000$ each year on postage.

Funding Amount and Duration. Relative to many other tax-credit programs, the $\$ 1,500$ maximum credit for $\mathrm{PV}$ and wind systems is at the low end of the range. A higher incentive may be necessary to generate more interest in these higher cost technologies, but it is unclear whether this is currently a barrier. In addition, the residential energy tax-credit program is not a self-supporting program. Current funding for the administration of RETC is obtained through a grant from the DOE's State Energy Program (SEP), and there is no way to predict whether SEP funding will remain available.

Outreach. Partnerships play a critical role in educating potential participants in Oregon's energy programs and issuing tax credits to residents. The RETC program has minimal funds for marketing, but interviewees assert that the credit is well known in the state. During the past 25 years, OROE has established partnerships that spread the word about the program. The agency reports that in-state contractors are very knowledgeable about the tax program and ensure that homeowners are aware of the benefits of applying for a tax credit. Contractors reported that the tax credit and other state financial incentives are valuable marketing tools to help convince consumers to install renewable energy technologies in their homes. Other partnerships that have been valuable to the program include those with renewable energy systems, conservation equipment vendors, utilities, engineering and architectural firms, the private sector, local governments, other state governments, and community action organizations.

Quality Assurance. The tax-credit program guarantees system performance by tying the incentive to energy production. The credit was not a production-based program from its inception, however, but was transitioned in the late 1980s. When the program began, the incentive was structured as an investment credit, calculated as a percentage of the system cost - the larger the system, the larger the tax credit. One reason for the change to a production-based program was to halt the oversizing of solar and other systems. Now, homeowners may be receiving slightly smaller tax credits under the production-based program, but the production efficiency of the systems installed has improved, and therefore, the homeowners may be saving more money.

Complementary Financial Incentives. Oregon offers several complementary financial incentives, including a loan program, a property tax exemption, and utility programs, with varying degrees of impact on the RETC program. The inconsistent implementation of net metering rules throughout the state may detract from program effectiveness. One solar installer who holds licenses in both Oregon and Washington reported that he receives about 10 phone calls from Oregonians for every phone call he receives from Washingtonians. $\mathrm{He}$ 
attributed this difference in interest primarily to Oregon's financial incentives, especially the loan and tax-credit programs.

Small-Scale Energy Loan Program (SELP). SELP provides loans to the residential, commercial, and public sectors for renewables projects and other energy projects. According to the Office of Energy, most residents who apply for the SELP also apply for the Residential Energy Tax Credit. However, a small fraction of residents who have used RETC financed their projects through SELP (see case study on page 101), presumably because more favorable financing opportunities - such as those offered by utilities, or new homeconstruction mortgages - are available, or residents do not need financing for lower cost solar hot-water systems.

Utility Programs. Attractive loan and rebate packages are available from a number of utilities in Oregon. For example, the Eugene Water and Electric Board (EWEB), Emerald Public Utility District, Ashland Electric, and others participate in The Bright Way To Heat Water program. For solar-water and pool-heating systems, rebates of $\$ 600$ to $\$ 1,200$ are available in addition to zero-interest loans of up to $\$ 4,000$. The Oregon Office of Energy and the utilities frequently bundle their programs. For instance, EWEB provides information about the residential energy tax credit on its Web site, including a link to the OROE site for more information.

Property-Tax Exemption. Oregon offers a property-tax exemption, whereby the value of renewable energy equipment is exempt from state property taxes. Like the tax-credit and loan programs, a variety of technologies are eligible - solar, wind, renewable transportation fueling facilities, and geothermal technologies. This exemption can be a valuable incentive for larger-scale or more costly projects and should be better promoted.

Net Metering. Oregon's net-metering law applies to customers with solar, wind, or hydropower systems of up to $25 \mathrm{~kW}$, although enrollment is limited to a total installed capacity of $0.5 \%$ of the utility's historical single-hour peak load. Stakeholders reported that the ease with which customers can establish net-metering agreements varies among utilities, and that the utilities are still climbing the knowledge curve in this area.

Public-Benefits Fund. Under the state's Public Benefits Fund, the Energy Trust of Oregon will invest money collected from customers of two of the state's utilities. The fund will support renewable energy, energy conservation and market transformation, low-income weatherization programs, and school energy programs. Incentives derived from this program will potentially work in concert with the tax credit to increase renewable energy technology deployment.

Infrastructure Issues. Factors external to the program that may be detracting from its effectiveness include the inconsistent implementation of interconnection and net-metering policies throughout the state. New contractor-licensing requirements for solar installers are expected to enhance program effectiveness for solar installations.

Interconnection. Stakeholders reported that the ease with which customers can establish interconnection agreements varies among utilities, and that the utilities are still climbing the 
knowledge curve in this area. Therefore, interconnection and net metering present similar challenges in Oregon.

Installer Licensing. Stakeholders interviewed anticipate that the new contractor-licensing requirements will enhance program effectiveness by improving the quality of solar hot-water and photovoltaic systems, and consumer confidence in the industry. The 2001 legislature passed a law requiring the licensing of all installers of solar hot-water and photovoltaic systems; the rules are being developed.

Other Influences. Other influences that impact the use of RETC include the prevalence of pro-renewable energy attitudes in the state and the relatively high cost of renewables. Progressive attitudes toward environmental and energy-conservation issues, together with an array of supportive renewable energy policies, have helped the state become one of the nation's leaders in solar installations. Policies encouraging renewables have been implemented despite the state's historically low electricity prices. Stakeholders reported that Y2K and recent price spikes in electricity costs have increased interest in renewable and energy-efficient technologies during the past few years in particular. Some observers noted a strong sense of "isolationist thinking" among some of the state's residents and a desire to live in close connection to the land. Oregon has a high level of activism among its renewable energy community, and there are a number of nonprofit organizations whose missions include the promotion of renewable energy. Oregon became the first state in the country to install photovoltaics on its capitol building in April 2002. 
ApPendix B: BUY-Down Program Case Studies 


\section{Summary of Findings}

The Photovoltaics (PV) Rebate Program has been an important catalyst for increasing the number of grid-tied PV systems in Florida. As a component of the Florida PV Buildings Program, it has also served as a model on how to establish a PV infrastructure within the state. During a period of three years, the program has helped increase the number of installations in the state dramatically. Of the 70+ systems currently installed in the state, 50 were installed as part of the PV Rebate Program. However, the program's future has been in limbo since funding ran out in early 2002. Currently, rebates are not offered, although a waiting list has been established in anticipation of renewed funding. Barriers to the deployment of PV in Florida include high equipment costs, interconnection and net-metering difficulties, an inadequate number of qualified installers, and public concern about system reliability. On the other hand, public awareness of the benefits of solar-energy technologies in the "Sunshine State" is relatively high. Those installing PV tend to be motivated by environmental reasons, energy security, and energy-reliability concerns.

Strengths of the rebate program were:

- the rebate's inclusion as part of an overall effort to improve system performance and boost the number of qualified and installers;

- the inclusion of utilities, schools, and public facilities as eligible recipients, which helped jump-start the program;

- quality-control requirements, including the use of pre-approved systems, installers, and system monitors, who help guarantee system performance and protect consumers;

- a high maximum incentive amount $(\$ 16,000)$ for residents; and

- an incentive for installing PV systems on model homes in order to increase awareness and acceptance of the technology.

Limitations of the rebate program included:

- an uncertain program funding duration and incentive amount;

- customer stalling due to an anticipation of possible renewed funding;

- a low initial incentive level (\$2/watt);

- a lengthy and detailed application process;

- an ineffective initial distribution mechanism through installers and utilities; and

- consumer discouragement resulting from an initial shortage of program-certified contractors.

It seems natural that a state nicknamed the Sunshine State would be a leader in the installation of solar technologies, and indeed, Florida is already a leader in solar water and pool heating. In the PV arena, Florida appears poised to experience a further surge in the number of PV installations if the state can maintain the momentum created by the PV Rebate Program. However, if programs and financial incentives are not made available to help lower the price of PV to a more affordable level, it appears that further progress might be halted. 


\section{Program Overview}

Background. Funded by a one-time $\$ 600,000$ grant $^{*}$ using oil overcharge funds, the PV Rebate Program was managed by the Florida Solar Energy Center (FSEC), a research institute of the University of Central Florida. FSEC is the largest and most active statesupported energy research center in the country. The primary goals of Florida's Photovoltaics (PV) Rebate Program were to (1) eliminate barriers to PV installation and (2) stimulate the adoption of PV by reducing up-front equipment costs. The funding was provided for the period from March 1999 through March 2002, or until all funds were exhausted-whichever came first. Of the total funding, $\$ 525,000$ was allocated for the rebates, and $\$ 75,000$ was set aside to purchase monitoring equipment for the systems installed. Funds were exhausted in January 2002, and it is uncertain whether additional funding will be made available. A request for additional funding was denied, but the state did allocate $\$ 750,000$ for solar on schools projects, of which $\$ 600,000$ will be used to provide PV rebates for hardware at the rate of $\$ 5$ per watt up to $\$ 20,000$.

Eligible Technologies. Grid-tied photovoltaic systems with a capacity of at least $1 \mathrm{~kW}$ were eligible for this rebate. In response to a survey about barriers to PV installation conducted by FSEC, some respondents advocated the inclusion of stand-alone systems. Although FSEC maintains that stand-alone systems compete well with other alternatives, the purpose of this pilot program was to grow the grid-connected market in Florida.

Eligible Applicants. Florida residents, businesses, developers, government agencies, educational facilities, and utilities that install PV systems connected to their local utility grid were eligible for the Florida Solar Energy Center's PV rebate.

Incentive Amount and Terms. Eligible residential applicants received \$4 per installed watt, with a maximum grant of $\$ 16,000$ per system. Commercial, school, and government applicants also received $\$ 4$ per installed watt but with a maximum of $\$ 40,000$ per system. Builders and developers were eligible for an incentive of $\$ 2,000$ for installing PV systems on model homes. Because all funds were depleted in early 2002, a waiting list has been established for possible future rebates.

Responding to participant needs and potential problems, FSEC increased the incentive amount and modified the distribution mechanism after the program's inception. At the beginning of the program, two utilities_-JEA and New Smyrna Beach Utilities Commission - were each awarded $\$ 100,000$ grants as part of a Request for Proposals (RFP) process to facilitate the implementation of four separate quality-control requirements as agreed to with Sandia National Laboratories. This grant award also provided funds for the utilities to offer rebates to customers who install PV systems. Initially, the rebate was $\$ 2 /$ watt, to be distributed through installers to the utilities' customers. However, several installers were not passing on the rebate to customers. In June 2001, with quality-control measures added, the program was changed to a straight $\$ 4 /$ watt for all eligible applicants, and the rebate was issued directly to the customer. Also, the initial cost cap of \$7/watt was removed at the request of industry.

\footnotetext{
${ }^{*}$ As part of a cooperative agreement with Sandia National Laboratories, through the Florida-based PV Southeast Regional Experiment Station (PV RES), the Florida Energy Office/Department of Community Affairs allocated a total of $\$ 600,000$ to the Photovoltaics (PV) Rebate Program.
} 
Application Process. There was a nine-step application process for the rebate program. The steps are listed below.

1. FSEC recommends that those who plan to apply for a rebate locate a licensed PV equipment installer and vendor to discuss relevant needs and financial constraints. A list of licensed installers and preapproved PV system designs appears on FSEC's Web site.

2. Applicants must complete a form, which can be obtained via mail, e-mail, or the Web. The application form is short- two pages - and simple.

3. Applicants obtain a copy of their local utility's interconnection procedures and an interconnection application form. FSEC's Web site provides a list of utility contacts to facilitate this step.

4. Applicants select a PV system design and submit it to FSEC for approval. FSEC provides several preapproved system designs.

5. Applicants submit the rebate application to FSEC, along with a copy of the one-page enduser agreement, which is available online.

6. Within 30 days of being notified of the receipt of an application, applicants must send FSEC proof that they have ordered or purchased eligible equipment.

7. Applicants install the system. FSEC will answer questions or offer advice in this capacity. A licensed installer must complete and submit a PV rebate-requirement checklist on behalf of the applicant.

8. Applicants send FSEC copies of all appropriate building permits and warrantees, and contact FSEC to schedule an acceptance test of the installed system.

9. Applicants send FSEC the invoice for payment within six months of applying for rebate funds. The one-page invoice is also available online.

This process was fairly detailed and involved relative to most other state rebate applications. In a February 2002 FSEC survey ${ }^{23}$ distributed to 800 individuals who had inquired about the PV Rebate Program, many respondents cited the lengthy application process as a barrier to participation.

Quality Assurance. Quality assurance was one of the cornerstones of the PV rebate program; Florida had among the most stringent requirements of any state incentive program. FSEC worked to guarantee system performance through the certification of PV installers, preapproval of system designs, inspection of installed systems, and post-installation monitoring.

Approved Installers. Under the rebate program, an FSEC-authorized contractor must have been used to install grid-tied systems; homeowners were not allowed to install systems themselves. A list of FSEC-authorized contractors is available from the FSEC Web site.

Approved PV System Designs. FSEC required that systems installed under the rebate program be preapproved. FSEC also worked with the customer's vendor or manufacturer to approve a desirable system. The principal goal of this process was to help ensure the safety and quality of installed PV systems, thereby providing assurance to installers, consumers, and financiers that approved designs meet established codes and industry-accepted practices. A design review needed to be completed before a system could be approved. FSEC engineers, with assistance from NREL and Sandia National Laboratories, approved the 
design plans. This process usually took about one month, depending on the completeness of the design documentation provided for review. More than 35 grid-connected PV systems manufactured by three different companies were approved by FSEC.

Acceptance Tests. FSEC conducted an acceptance test for each installation eligible for a rebate. This test (1) ensured that the system installed agreed with the design that was approved, (2) ensured that all system components were functioning properly, (3) ensured that the power output was consistent with expectations, and (4) helped ensure that the installed system complied with all applicable codes. In addition, FSEC offered to assist local code officials with PV system inspections on request, and continued to offer this service until they were more familiar with the technology.

Monitoring. Each system installed under the program had one of three types of system monitoring. Data loggers provided instantaneous data available online at http://www.infomonitors.com. Time-of-day meters and monthly meter readings provided additional system information. Systems participating in the program had to pass an acceptance test before the rebate was provided. FSEC maintained cost data on all the systems.

Outreach Activities. Florida's PV Rebate Program was promoted on the Florida Solar Energy Center's Web site. As noted above, FSEC's Web site guided applicants through the process, providing periodic updates on the program, access to the application form, a list of utility contacts, multiple preapproved solar designs and various other resources. In addition, FSEC employed a public-relations specialist who distributed news releases regarding the program to every newspaper in Florida in the summer of 2001. According to the program manager, ensuing media attention played a direct role in generating strong public interest in the rebate, which translated into a steep increase in the number of inquiries and applications received by FSEC. The program manager also noted that many applicants were directed to FSEC's Web site via the Database of State Incentives for Renewable Energy (DSIRE) Web site (www.dsireusa.org). 


\section{Program Results}

According to FSEC, there are currently about 70 grid-tied PV systems in Florida. Of these 70 systems, the owners of 50 projects in 11 different electric utility service territories participated in the PV Rebate Program. Table 10 below provides program results, including the annual number of rebate applications received, capacity installed, total funding, total project costs, and rebate recipients.

Table 10: Florida Photovoltaics Rebate Program Results*

\begin{tabular}{||c|c|c|c|c|c||}
\hline Year & \# of Rebates* & $\begin{array}{c}\text { Capacity } \\
\text { (kW) }\end{array}$ & $\begin{array}{c}\text { Total } \\
\text { Funding }\end{array}$ & $\begin{array}{c}\text { Project } \\
\text { Costs }\end{array}$ & Recipients \\
\hline 1999 & 13 & 31 & 112,012 & 206,306 & $\begin{array}{c}77 \% \text { Residential } \\
23 \% \text { Public Facilities }\end{array}$ \\
\hline 2000 & 2 & 14 & 15,800 & 214,950 & $100 \%$ Public Facilities \\
\hline 2001 & 31 & 117 & 356,880 & $1,035,878$ & $\begin{array}{c}42 \% \text { Residential } \\
58 \% \text { Public Facilities }\end{array}$ \\
\hline $1 / 02$ & 4 & 11 & 45,360 & 95,775 & $100 \%$ Residential \\
\hline \hline Total & $\mathbf{5 0}$ & $\mathbf{1 7 3}$ & $\mathbf{\$ 5 3 0 , 0 5 2}$ & $\mathbf{\$ 1 , 5 5 2 , 9 0 9}$ & $\begin{array}{c}\mathbf{5 4 \%} \text { Residential } \\
\mathbf{4 6 \%} \text { Public Facilities }\end{array}$ \\
\hline
\end{tabular}

* based on the date application was received by FSEC

Of the 50 systems funded by the program, 25 were installed on homes, 18 on schools, five on commercial or public facilities, and two on model homes. The 11 electric utility service territories involved included six municipal utilities, four investor-owned utilities, and one rural electric cooperative.

Residential systems range in size from $1.2 \mathrm{~kW}$ to $4.4 \mathrm{~kW}$ and account for nearly $75 \mathrm{~kW}$ of installed capacity. School systems range in size from $3.6 \mathrm{~kW}$ to $9.6 \mathrm{~kW}$ and contribute a total of almost $76 \mathrm{~kW}$ of installed capacity. Most of these schools received rebates through JEA's grant from FSEC. FSEC provided several grade-specific curriculum packages as well as teacher training workshops at schools where systems were installed. The remaining five systems are owned by utilities or businesses and account for nearly $22 \mathrm{~kW}$ of installed capacity.

\section{Observations and Lessons Learned}

The PV rebate has played an active role in encouraging the installation of grid-tied PV systems in Florida. By providing funding assistance for approximately $70 \%$ of the grid-tied systems in the state, the rebate successfully met its goals of stimulating the adoption of PV. The program identified numerous barriers to PV deployment and developed an increasingly effective means of quality control. However, few new PV installations are expected in Florida without additional program funding.

The PV rebate program was a part of FSEC's PV Buildings Program, which emphasizes the value of monitoring PV systems to provide quality control and subsequently make recommendations for improvements of the systems. As a part of this quality-control emphasis, and in an effort to eliminate barriers to PV installation, the Florida Photovoltaic 
Rebate Program Consumer Satisfaction Questionnaire was distributed in February 2002 to approximately 800 people who had inquired about the program since 1999. Preliminary survey results - based on the 100 responses received - suggest that the two most significant barriers to PV installation are (1) high PV equipment costs and (2) interconnection difficulties and costs. One of these barriers now may be removed with the approval of Florida's interconnection standards in early 2002.

Some questionnaire respondents said that the rebate amount should be higher, expressing a desire to pay a net price more along the lines of $\$ 2$ or $\$ 3$ per watt, as opposed to the $\$ 4$ to $\$ 6$ per watt they currently pay under terms of the rebate. One official from the municipal utility, Utilities Commission of New Smyrna Beach, stated that it would not be likely to continue its PV rebate program if the FSEC program is not refunded. The utility's program, funded in part by FSEC's rebate program, was used to install mostly residential systems.

Other obstacles cited in the questionnaire results include the following:

- the absence of a statewide net-metering policy;

- a lack of installers;

- the rebate program's complexity;

- an insufficient incentive amount; and

- the ineligibility of stand-alone systems.

Program Design and Implementation. Program features influencing the effectiveness of Florida's Photovoltaics Rebate Program include funding stability and program duration, applicant eligibility, and quality assurance.

Funding Stability and Duration. As mentioned earlier in this section, Florida's Photovoltaics Rebate Program succeeded in boosting the adoption and awareness of grid-tied PV systems in Florida. The program's initial three-year funding proved adequate to induce interested parties to invest. Presuming the program will indeed be refunded, potential customers may delay installation of PV systems indefinitely. The effect of the abrupt disappearance of the rebate and uncertainty about future funding on the market remains to be seen and will provide valuable lessons for other state programs.

Eligibility. Broad eligibility guidelines helped popularize the rebate program. Several PV systems were installed on schools, which serve as excellent demonstration sites. Also eligible for the rebate were builders and developers, who received a rebate of $\$ 2,000$ each for installing PV systems on two model homes in Florida. The most obvious benefit of installing PV on model homes is the exposure of the public to PV in a "standard" home. These model homes reinforce the idea that PV is a sound, accepted technology that can be incorporated into normal homes.

Furthermore, utilities were eligible to participate in the program. Early in the program, rebates were provided to homeowners indirectly through utilities and installers. Two municipal utilities, JEA (formerly Jacksonville Electric Authority) and New Smyrna Beach, applied for and received grants of up to $\$ 100,000$. Soon afterward, other utilities followed suit; the majority of the initial applications received were submitted by municipal utilities or their customers. As a result, these communities now have a number of PV installations. New 
Smyrna Beach designed a rebate program to help residential customers purchase PV systems. Under this program, the homeowner was responsible for paying one-third of the system cost, while one-third came from the rebate, and one-third was provided by the utility.

FSEC offers a separate program, SunSmart, which aims to promote municipal utility solar and green-pricing programs. Many of the utilities that participated in SunSmart submitted applications for PV rebates.

Quality Assurance. FSEC placed strong emphasis on quality assurance with respect to the rebate program. When the program began, there were five FSEC-authorized contractors, whose names were available upon request. Given certification requirements, potential customers experienced difficulty finding a qualified installer early in the program and cited this as a barrier to installing PV according to the FSEC survey. Stakeholders interviewed for this case study concurred. Accordingly, as of May 2002, the FSEC Web site maintained a list of more than 20 authorized contractors.

Stakeholders stressed the importance of providing consumers with a list of approved PV system designs from which to choose. One installer explained that this expedited the entire rebate process and offered a level of comfort to consumers, installers, and building inspectors alike. Approved designs assisted the homeowner by providing a population of approved systems from which to choose. Approved PV system designs also benefited FSEC, which already had undertaken the rigorous process of approving these technologies. The approved designs assisted the installers because the package components were designed to work together, which often resulted in a smoother installation process. The approved system design also facilitated the roles of building inspectors, who examined UL-approved systems installed by certified contractors. FSEC explained that its PV design approval results, available on the FSEC Web site, were valuable to consumers, installers, building inspectors, and others within the industry. FSEC provided this service free of charge, although a fee may be implemented in the future.

Alternative Approaches. Respondents to FSEC's questionnaire cited examples of subsidies that might have increased their participation in the program, including $0 \%$ interest-rate loans and a one-point reduction on mortgages or home-equity loans.

Complementary Financial Incentives. Florida offers few complementary incentives that bolster the appeal of the Photovoltaics Rebate Program. These include a sales-tax exemption and limited net metering, both discussed below.

Sales-Tax Exemption. Florida offers a sales-tax exemption for solar energy equipment, although the Florida Solar Energy Industries Association asserts that this exemption is of more philosophical and public relations import than economic significance. It is worth noting that Florida does not have a state personal income tax. This is one of the reasons that the sales-tax exemption was pursued; there were few other options for a tax incentive that would impact all consumers-businesses and individuals alike.

Net Metering. JEA offers net metering and will provide - at the customer's expense- a second meter to measure energy deliveries to the utility. New Smyrna Beach Utilities Commission also offers net metering. However, some respondents to the Florida 
Photovoltaic Rebate Program Consumer Satisfaction Questionnaire complained that the absence of a statewide net-metering policy in Florida frustrated their desire to purchase a PV system.

Infrastructure. External factors that influenced the rebate program's ultimate impact include Florida's interconnection standards and solar contractor-licensing requirements.

Interconnection. Another element of infrastructure development is collaborating with utilities to establish workable interconnection standards. The No. 2 barrier to PV installation (behind cost of PV equipment), according to the preliminary results of the survey, was the difficulty of interconnecting with utility grids. Survey respondents stated that interconnection with utility grids was difficult and costly. Moreover, the fact that net metering is not mandatory in Florida was cited by respondents as a barrier to program success.

Prior to the PV Rebate Program, few if any of the 11 utilities that were in the electric utility service areas where PV systems were installed had interconnection agreements or netmetering policies in place. The PV Rebate Program helped these utilities address interconnection and net-metering questions and issues, and establish policies that could be used by future customers.

After nearly three years of effort and debate, an interconnection rule was approved by the Florida Public Service Commission in February 2002. Rule 25-6.065 of the Florida Administrative Code established standards for the interconnection of $10 \mathrm{~kW}$ or smaller photovoltaic systems (SPS) with the electric grid and required investor-owned electric utilities to file a standard interconnection agreement with the commission. Ironically, the rebate program ended in March 2002, the same month that the standard interconnection agreements were due. The rebate program is structured so that customers must obtain an interconnection application from their utility prior to selecting a PV system design and submitting it to FSEC for approval.

The rule does not require net metering, but allows the utility to offer it voluntarily. Under the rule, a single meter would be used, unless the utility opts to pay to install a dual-metering system. If excess electricity is generated by the system, the utility may carry the credit forward for up to 12 months. The utility is not required to pay the customer for electricity the customer generates. A number of municipal utilities and rural electric cooperatives have voluntarily established net-metering policies.

Solar Contractor Licensing. All solar installers in Florida wishing to install grid-tied PV systems must be licensed with either a solar or electrical contractor license. In addition, a free authorization examination was required for inclusion as an FSEC authorized contractor. For solar thermal, Florida requires either a solar, plumbing, or pool contractor license. Steps are under way to develop national standards for qualifying training programs and installers.

Other Influences. Even with the PV rebate, the survey results showed that the cost of PV was found to be prohibitive to most Florida customers. Other stakeholders confirmed that cost was a deterrent. A utility representative reported that the nine homeowners who installed systems in their service area as part of the rebate program did so for environmental — as 
opposed to financial - reasons. He stated that the utility likely will discontinue its own rebate program if state rebate funding is permanently discontinued.

Stakeholders reported that within the past 12-18 months they have received several telephone inquiries daily regarding the rebate program. Many among the general public in Florida appear to be aware of the PV Rebate Program and have an interest in exploring the program as an option. However, stakeholders also reported that they think the majority of participants in the program were those who had been considering a solar installation, but would not have moved forward with the project without the financial incentive provided by the PV Rebate Program. Stakeholders believed that without the PV Rebate Program, the number of PV installations would dwindle back down to only a handful of systems per year. Prior to the rebate, there was essentially no market for grid-tied PV systems in Florida.

Stakeholders in Florida agree that there is still a need for consumer awareness and education about PV and other renewable technologies in Florida. However, they cite the popularity of the PV Rebate Program and the current waiting list as factors that many Floridians are already somewhat familiar with PV. One of the main findings in the survey-that the No. 1 roadblock to more installations is the high price of PV system installations - further indicates that a level of consumer awareness already exists. 


\section{Summary of Findings}

The Renewable Energy Resources program is poised to play a significant role in stimulating renewable energy investment in Illinois. With about $80 \%$ of RERP participants in ComEd's territory, the utility's net-metering policy and promotional efforts are considered to contribute greatly to the decision of many program participants to install systems. The 69 rebates issued thus far have supported an equal number of residential solar-thermal and PV applications. Although a wide variety of technologies are eligible for the grant, the vast majority of the 60 grant awards has supported PV installations, including many residential systems. The grant program enjoyed early success partnering with other funds to support numerous school and museum installations.

Homeowners who have taken advantage of the incentive program tend to be those who have been interested in renewable energy technologies for a long time and are motivated by environmental responsibility, energy independence, or other non-economic factors. The availability of the RERP appears to be the deal-maker for them. Yet, some observers argue that the program is performing below its potential. A minimal marketing effort, an inadequate number of qualified installers, inconsistent net-metering and interconnection policies throughout the state, and relatively high equipment costs appear to compromise the effectiveness of the program. Few businesses have participated in the program thus far, presumably due to cost constraints.

RERP's strengths include:

- a generous incentive;

- a specified, 10-year program duration that effectively builds consumer confidence;

- the wide variety of renewable technologies eligible for funding;

- cooperation from ComEd, which allows simple interconnection and net metering;

- flexibility to add installer requirements to ensure higher quality; and

- the availability of funding to public entities.

Program limitations include:

- insufficient outreach and education efforts to contractors and the general public;

- minimal measures to ensure adequate system performance; and

- a potentially cumbersome grant-application process for residents.

Educating consumers about renewable energy technologies requires the efforts of the program administrator, the renewable energy industry, and advocates alike. Partnering with education and training institutions to develop the industry infrastructure can provide additional consumer outreach and promotion opportunities that go beyond the scope possible for the small-staffed RERP. And certainly, a statewide net-metering policy would increase the financial benefit to all participants. Other favorable policies already in existence, such as the property-tax exemption, should be promoted as well. 


\section{Program Overview}

Background. Through its 1997 electric utility restructuring law (Public Act 90-561), the Illinois legislature established the Renewable Energy Resources Program (RERP) for the purpose of fostering investment in and use of renewable energy resources within the state of Illinois. The Illinois Department of Commerce and Community Affairs (DCCA) administers the program, supporting a variety of renewable energy technologies through grants (for large systems) and rebates (for small systems). RERP program staff consists of one full-time individual.

RERP is funded by the Renewable Energy Resources Trust Fund, which receives approximately $\$ 5$ million per year through a monthly surcharge on customers' gas and electric bills. Fund collection began in 1998 and will continue for 10 years, at which time the program will undergo legislative review.

Eligible Technologies. Renewable resources eligible for the RERP grant include solar thermal, photovoltaics, wind, biomass from dedicated crop and organic waste biomass, the retrofit of existing hydroelectric systems, and biogas fuel cells. The RERP rebate applies to small photovoltaic and solar-thermal systems. Only projects built after January 1, 1998, and within Illinois' borders are eligible for funding.

Eligible Applicants. Eligible applicants for grants or rebates include associations, individuals, private companies, public and private schools, colleges and universities, nonprofit organizations, and units of state and local government. Potential recipients for program funding must be located within the service area of an investor-owned or a municipal gas or electric utility, or an electric cooperative that imposes the Renewable Energy Resources and Coal Technology Development Assistance Charge.

Incentive Amount and Terms. The RERP offers among the most generous incentives for renewables in the country. Incentive amounts and maximum funding vary according to technology and, for some technologies, project size. DCCA may provide up to, but not more than, the funding amounts shown in Table 11 for a single project.

Eligible expenditures for grant funding were initially determined based on the type of project, and included the costs of design, construction, legal services, travel, data processing, and other nonequipment. However, modifications to the program in December 2001 included provisions that only expenditures on equipment and installation are eligible for funding. Other program modifications in December 2001 include a new requirement for installers to be bonded, licensed, and insured. However, program participants are still allowed to install their own systems without using a contractor. 
Table 11: Illinois Renewable Energy Resources Program Funding Categories and Limits

\begin{tabular}{|c|c|}
\hline Technology & Maximum Incentive Amount \\
\hline Photovoltaic Systems $>2 \mathrm{~kW}$ (grant) & $\begin{array}{l}60 \% \text { up to a maximum of } \$ 6.00 \text { per watt with a } \\
\text { maximum grant of } \$ 300,000\end{array}$ \\
\hline Photovoltaic Systems $0.5 \mathrm{~kW}-2 \mathrm{~kW}$ (rebate) & $60 \%$ with a maximum rebate of $\$ 5,000$ \\
\hline \multicolumn{2}{|l|}{ Wind Farm $^{*}$} \\
\hline $10 \mathrm{~kW}$ to $999 \mathrm{~kW}$ & $\begin{array}{l}50 \% \text { up to a maximum of } \$ 2.00 \text { per watt with a } \\
\text { maximum grant of } \$ 400,000\end{array}$ \\
\hline 1 Megawatt to 10 Megawatt & $\begin{array}{l}35 \% \text { of the project costs with a maximum grant of } \\
\$ 1,000,000\end{array}$ \\
\hline Over 10 Megawatts & $\begin{array}{l}10 \% \text { of the projects cost with a maximum grant of } \\
\$ 2,750,000\end{array}$ \\
\hline Dedicated Crops Grown for Energy Production & $50 \%$ with a maximum grant of $\$ 150,000$ \\
\hline Solar Thermal Energy (grant) & $50 \%$ with a maximum grant of $\$ 150,000$ \\
\hline Solar Thermal Energy (rebate) & $50 \%$ with a maximum rebate of $\$ 5,000$ \\
\hline Organic Waste Biomass (Electrical Production) & $50 \%$ with a maximum grant of $\$ 550,000$ \\
\hline Organic Waste Biomass (Heat Production) ${ }^{\dagger}$ & $50 \%$ with a maximum grant of $\$ 350,000$ \\
\hline Fuel Cell & $50 \%$ with a maximum grant of $\$ 550,000$ \\
\hline Hydropower & $50 \%$ with a maximum grant of $\$ 1,000,000$ \\
\hline
\end{tabular}

Application Process. The application process for the RERP rebate, which was intended primarily for residential users, is fairly simple. The application consists of a two-page form with basic owner, system, and project-cost information. Applicants attach a copy of the invoice and the installer's certification that the system has been installed according to applicable codes. The grant application is relatively lengthy and more comprehensive. It requires greater detail regarding the history of the applicant, project budget, statement of work with proposed tasks and deliverables, and a statement of expected outcomes and benefits to the applicant and state. Applications are accepted on an ongoing basis.

Outreach Activities. The RERP program is promoted through the DCCA Web site, which includes detailed program and contact information. ComEd also features RERP program information on its Web site in conjunction with its description of the utility's net-metering program. Although the program administrator has attended and made presentations at several regional and statewide meetings, there has been no systematic outreach effort targeting potential participants.

\section{Program Results}

Table 12 provides the number, type, funding, combined size, and recipients of systems installed under the RERP program. At of the end of 2001, after nearly three years in operation, the RERP rebate program has provided about $\$ 240,000$ in funding for $35 \mathrm{PV}$ installations (nearly $27 \mathrm{~kW}$ combined) and a nearly equal number of solar-thermal systems.

\footnotetext{
* Prior to December 5, 2001, the incentive for wind projects was set at a maximum cost share of $60 \%$ and $\$ 300,000$ for all wind systems under $10 \mathrm{~kW}$.

${ }^{\dagger}$ Eligible technology as of December 5, 2001.
} 
Homeowners, as expected, have been the primary recipients of the rebates. The number of recipients steadily increased from 14 in 1999 to 36 in 2001.

The grant program has supplied close to $\$ 8$ million in funding for about 60 projects totaling nearly $24 \mathrm{MW}$. Nearly $80 \%$ of these projects are PV installations (665 kW total), with most of the remaining $20 \%$ divided among several utility-scale landfill gas systems, hydroelectric retrofits, and wind projects. Grant recipients increased during the first three years, from 10 in 1999 to 27 in 2001. The RERP worked in concert with ComEd and the City of Chicago early in the program to fund about a dozen PV systems on museums and schools in the City of Chicago.

Table 12: Illinois Renewable Energy Resources Program Results*

\begin{tabular}{|c|c|c|c|c|c|c|}
\hline Incentive & $\begin{array}{c}\text { \# of } \\
\text { Projects }\end{array}$ & Technology & Capacity & $\begin{array}{c}\text { Total } \\
\text { Funding }\end{array}$ & $\begin{array}{c}\text { Project } \\
\text { Costs }\end{array}$ & Recipients \\
\hline Rebate & $\begin{array}{l}\text { 1999: } 14 \\
\text { 2000: } 19 \\
\text { 2001: } 36 \\
\text { Total: } 69\end{array}$ & $\begin{array}{l}\text { Photovoltaics: } 50 \% \\
\text { Solar Thermal: } 50 \%\end{array}$ & $28 \mathrm{~kW}$ & $\$ 240,000$ & $\$ 496,000$ & $100 \%$ Residents \\
\hline Grant & $\begin{array}{c}\text { 1999: } 10 \\
\text { 2000: } 23 \\
\text { 2001: } 27 \\
\text { Total: } 60\end{array}$ & $\begin{array}{lr}\text { PV: } & 78 \% \\
\text { Wind: } & 8 \% \\
\text { Hydro: } & 3 \% \\
\text { Landfill gas: } & 3 \% \\
\text { Thermal: } & 3 \% \\
\text { Digester: } & 2 \%\end{array}$ & $24 \mathrm{MW}$ & $\$ 7.8 \mathrm{M}$ & $\$ 42.6 \mathrm{M}$ & $\begin{array}{ll}50 \% & \text { Residents } \\
30 \% & \text { Public } \\
& \text { Facilities } \\
20 \% & \text { Commercial }\end{array}$ \\
\hline
\end{tabular}

* February 1999 - December 2001; based on date application was received

Surprisingly, almost 50\% of grant participants are homeowners who have opted for larger PV systems - those greater than $2 \mathrm{~kW}$. The assumption was that the vast majority of homeowners would take advantage of the rebate, which is for systems between $500 \mathrm{~W}$ and 2 $\mathrm{kW}$ - but that has not turned out to be the case. The grant program offers the most generous incentives for PV in the country, at a $60 \%$ cost share with a maximum of $\$ 300,000$ - well above even the most ambitious homeowner PV installation. Those interviewed speculated that concerns about energy security and reliability, and a desire for self-sufficiency, have motivated some homeowners to install large systems to produce a significant portion of their electricity needs.

The small-commercial sector, on the other hand, has not been enticed by the generous incentives, presumably because decision making in most cases is informed primarily by economic factors. Most companies are likely to consider the payback unacceptable even with the high incentive level. Alternatively, a lack of promotional and educational efforts targeting the sector also may contribute to the lack of participation.

About $80 \%$ of program participants are in ComEd's utility territory, making them eligible for net metering - an added financial incentive. ComEd has a simple interconnection agreement and will replace a customer's meter free of charge. 


\section{Observations and Lessons Learned}

In general, the RERP program has seen a modest level of participation during the past three years. Although there were no stated goals for capacity installed or number of participants at the program's outset, some stakeholders felt that the participation level is below the program's potential. The program is considered to have been most effective at providing the incremental economic benefit to those homeowners who have had long-standing interest in installing a solar-energy system. The economics of investing in renewables may be the major barrier to participation by small commercial facilities. Museums and schools, and ultimately the general public, also have benefited from the RERP-supported projects in the City of Chicago. The key factors influencing program effectiveness are discussed below in terms of program design and implementation, complementary financial incentives, infrastructure issues, and other influences.

Program Design and Implementation. Some of the key factors contributing to RERP's effectiveness are the generous cost share, funding duration, and eligibility guidelines. The limited outreach component, limited quality-assurance measures, and potentially burdensome grant application are considered to detract from the program's effectiveness.

Funding Amount and Duration. RERP's incentive level is among the highest in the country, and in some circumstances, the highest in the country. Furthermore, the 10-year program duration provides an amount of certainty not afforded by some other state incentives that may be funded on a yearly basis, or whose funding could be eliminated abruptly based on a state's budgetary constraints.

Eligibility. The program also considers a wide variety of technologies and sectors eligible, allowing a range of Illinois' renewable energy resources to be developed by virtually any type of organization or individual. The fact that public facilities are eligible for the grant helped jump-start the program and generate publicity in addition to educational opportunities.

Outreach. The primary program-specific factor that may be limiting the level of participation of the residential and small-commercial sector is the lack of a systematic outreach and education component to consumers as well as to installers. There appears to be a great deal of interest in the program, but individuals appear to have unrealistic expectations about the impact of a small PV system on their electric bills as compared to the up-front cost. ComEd's promotion of the program, together with other favorable policies, may have a strong influence on the number of participants in its territory. Participation from customers in other territories could be bolstered with a more systematic outreach effort and partnership with other utilities.

Quality Assurance. The absence of installer qualification requirements for RERP-funded system installers is considered to undermine program effectiveness. Past experience with federal tax credits in the 1970s and 1980s has shown that creating a market stimulus, with incentives such as RERP's generous grants and rebates, can overwhelm a fledgling industry infrastructure, resulting in poor-quality installations by inadequately trained contractors. Early system failures are likely to discourage other customers from investing in renewables. In fact, a lack of trained installers indeed has posed problems for the RERP. Some systems installed under the grant program were installed incorrectly and failed to work properly. 
Fortunately, the program administrator has the flexibility to make necessary changes to the program in light of these experiences. As of December 2001, in order for systems to be eligible for funding, installers must be licensed, bonded, and insured. Furthermore, a solar installer training program is being developed. The RERP has set aside $\$ 1.75$ million to install solar-energy systems on electrical trade associations, apprenticeship associations, and local technical community colleges that will be used in conjunction with installer training programs. A request for proposals for implementing the training program will be issued to potential institutional partners in early 2002.

Application Process. The grant application requirements have both negative and positive impacts on program effectiveness. In designing the detailed grant application, the program administrator's intention was to ensure that applicants had done adequate research into the technical specifications and associated costs - and had developed a logical and clear work plan-before allocating what could amount to more than $\$ 1$ million to a project. However, for many homeowners, this level of detail may seem overly burdensome. Although homeowners have not complained to the program administrator, one installer noted that some applicants view the application process as intimidating.

Complementary Financial Incentives. Two complementary financial incentives have had varied impacts on the effectiveness of the RERP — net metering and the property-tax exemption.

Net Metering. The primary incentive that is considered to have encouraged RERP participation is ComEd's net-metering experiment. The utility allows systems of less than 40 $\mathrm{kW}$ to be net metered. The utility has a simple interconnection agreement and will install a new meter at no charge. ComEd's support of and cooperation with the RERP has smoothed the path to interconnection; this has proven to be a significant roadblock in other states. In fact, utilities in other parts of the state do not offer net metering, and grant and rebate recipients in those territories have experienced difficulties establishing interconnection agreements.

Property-Tax Exemption. The state's property-tax exemption allows renewable energy systems to be assessed for tax purposes at a value no greater than conventional heating systems. While this policy clearly has financial benefits for program participants, it is poorly promoted. In fact, one installer was not even aware of the property-tax incentive. No information is made available to potential participants, and the information does not appear on the program Web site. Program participants often find out the exemption after installation. While the exemption currently does not contribute to RERP program effectiveness, it has the potential to aid the program if it is promoted as an additional financial incentive included in the overall economic analysis of a potential renewable energy project.

Infrastructure Issues. A weak dealer network and an inadequate number of qualified installers appear to limit the effectiveness of the RERP; while ComEd's simple interconnection agreement and supportive stance on the deployment of grid-connected renewables may have boosted participation in the program thus far. 
Dealer/Installer Infrastructure. According to interviewees, program participants have had difficulty finding qualified installers. Moreover, in some cases, qualified installers charge an exorbitant amount of money. These factors discourage adoption of renewable energy technologies and effectively limit potential RERP participants.

Interconnection. As discussed above with respect to net metering, customers in ComEd's territory enjoy a smooth and cooperative interconnection process with the added benefit of net metering. Customers in other territories have experienced difficulty securing interconnection agreements from their utilities.

Other Influences. Beyond program-specific issues and policy influences, there are several other factors that impact the level of participation. Stakeholders interviewed identified public concerns about energy security and interest in self-sufficiency as the primary external influences that contribute to program effectiveness. Circumstances considered to reduce program participation are the relatively high cost of renewable energy technologies and relatively low electricity rates.

According to the stakeholders interviewed, homeowners who have taken advantage of the incentive program tend to be those interested in renewable energy technologies for a long time. Although motivated by environmental responsibility, energy independence, or other noneconomic factors, the availability of the RERP appears to be the deal-maker for them. For example, in the town of Stelle, Illinois, a planned community with about 50 homes and a population of 110 , about $20 \%$ of the homes use renewable energy resources to provide electricity or hot water. This intentional community was created to provide a spiritual environment and foster self-sufficiency. Residents tend to be in the middle- to upper-middle income level and have a relatively high education level. These individuals are motivated by noneconomic factors including environmental responsibility, self-sufficiency, and energy security.

Concerns about Y2K, the energy crisis in California, the Middle East conflict, and more recently, terrorist attacks have stimulated a greater interest in alternative energy. In fact, some homeowners are opting for systems greater than the $2 \mathrm{~kW}$ capacity limit for the rebate program.

Finally, even with the large RERP incentive, the economics of investing in renewable energy technologies at the homeowner and small-commercial scale still may not be considered attractive enough to stimulate more deployment. Solar and wind equipment costs have actually increased in recent months - reportedly because of increased demand in California and other parts of the country with incentive programs or energy reliability problems. Because of these negative influences, compounded by relatively low electricity costs in Illinois, individuals and organizations are not driven to invest in renewable energy technologies unless strongly motivated by noneconomic factors. 


\section{Summary of Findings}

New York's Residential PV Program, administered by the New York State Energy Research and Development Authority (NYSERDA), is poised to play a significant role in stimulating the state's PV market. The buy-down and rebate offered through individual distributors is just one component of the state's overall PV market-development strategy. The incentives can work in concert with the state's residential PV tax credit, low-interest loan program, and net metering. However, only 34 homeowners have benefited from the program during the past two years despite tremendous public interest at promotional events. The cumbersome utility interconnection process is considered the primary barrier limiting deployment of residential photovoltaics, and thus participation in the program. Other factors discouraging investment in PV include high equipment costs, insufficient public understanding of the benefits and costs of PV, and difficulty securing low-interest financing for PV. Residents who install PV tend to be motivated by concerns about energy security, a desire to reduce dependence on utilities, environmental stewardship, and high electricity costs. Early adopters have been interested in solar for a long time, and the incentives acted as the deal-maker for them.

Program strengths include:

- the inclusion of the incentive as part of a holistic approach to market development, including outreach and education, and the development of product distribution channels;

- an easy application process;

- a beneficial coordination with other state residential PV incentives;

- the incorporation of monitoring equipment to validate system performance; and

- an adequate incentive level.

Limitations associated with the program include:

- the absence of a mechanism for other PV suppliers to participate after the initial contracts are awarded (effectively limiting technology choices and competition);

- the existence of a separate incentive program that limits a coherent and simplified marketing message;

- uncertain program funding and duration;

- an inability to gather monitoring data consistently from individual dealers on a regular basis.

Buy-down and rebate programs can be a potent market driver for residential PV, but they must be accompanied by complementary incentives and policies to help build a sustainable market, including a streamlined interconnection process, product marketing and consumer education, installer training, and low-cost financing options. Educating and partnering with utilities, financial institutions, the state's Public Service Commission, and the renewable energy industry are necessary to reach workable solutions to these challenges. 


\section{Program Overview}

Funding and Administration. New York's Residential Photovoltaics (PV) Program is a component of the New York Energy $\$$ mart $^{\text {SM }}$ program, a public-benefits initiative designed to lower electricity costs by encouraging the use of energy efficiency and renewable energy technologies. The Energy \$mart ${ }^{\mathrm{SM}}$ program, administered by the New York State Energy Research and Development Authority (NYSERDA), is funded by a system benefits charge on the electricity transmitted and distributed by New York investor-owned utilities, and paid for by electricity consumers.

The goal of the Residential PV Program is to help create a sustainable residential market for photovoltaic technologies. In 1999, NYSERDA funded three PV suppliers through a Request for Proposals process to build distribution channels to enhance their capabilities to market to the residential sector. The three suppliers were able to develop approaches that they felt would most effectively achieve their goals. SunWize opted to offer a consumer rebate, while AstroPower proposed an outreach/education program and a buy-down program.

Each of the two companies was allotted $\$ 500,000$ through 2002, although the programs will continue until the funds are depleted. SunWize and AstroPower each projected that 100 systems would be installed during the lives of their respective programs. To track progress, AstroPower and SunWize submit quarterly reports to NYSERDA with installation and sales details, monitoring information, training sessions conducted, a list of dealers, and problems and solutions. (A third company, Four Seasons, received $\$ 250,000$ for product development and the testing of a laminated PV glass module for sunrooms, but was not involved in the incentive program and later withdrew from the program.)

With the extension of the systems-benefits charges through 2006, NYSERDA has been able to develop additional components of the Residential PV Program. For example, in conjunction with the Interstate Renewable Energy Council (IREC), the Institute for Sustainable Power (ISP) and the North American Board of Certified Energy Practitioners, NYSERDA is putting in place the infrastructure for the training and certification for PV installers. In addition, NYSERDA is contracting with two firms to work with home builders in each utility franchise area (excluding Long Island Power Authority) to incorporate PV into Energy Star Homes. The goal is to have two subdivisions in each utility area that have at least five Energy Star Homes. NYSERDA will cover 100\% of the cost for a PV system installed on the model home and a reduced incentive for the next two homes in each subdivision.

Eligible Technologies. Grid-tied photovoltaic systems less than $10 \mathrm{~kW}$ are eligible for this program.

Eligible Applicants. As its name implies, this program applies only to New York residents. In addition, the applicant must be a customer of one of the investor-owned utilities participating in the system benefits charge.

Incentive Amount and Terms. SunWize offers a rebate of $\$ 3 /$ watt for up to $50 \%$ of the installed cost, with a maximum incentive amount of $\$ 7,500$. AstroPower offers a buy-down of $\$ 3 /$ watt - essentially a discount taken off the bottom line at the time of sale. 
Application Process. The application process is fairly easy, with little or no paperwork involved. For SunWize systems, the consumer fills out a simple form and submits it along with his or her utility interconnection agreement after the system has been installed and approved by the utility. SunWize, in turn, sends the customer a rebate check. Because AstroPower's program is essentially a discount taken from the bottom line at the time of sale, there is no application.

Quality Assurance. Each system must be monitored following installation to ensure that the system operates according to its design. Although monitoring increases the administrative burden on the dealer and NYSERDA, it is considered critical that early adopters are confident in their decision to install photovoltaics. Withholding a portion of the funds from the dealer provides an incentive to follow through with monitoring and quality-assurance requirements. In the case of SunWize, $20 \%$ of the incentive is withheld until the company provides system production data for a two-year period. SunWize, in turn, provides a monetary incentive to its dealers to provide data every six months. Monitoring has been challenging thus far, given the logistics and effort required to collect information from each dealer; therefore little data is available at this time. Monitoring efforts will likely be decreased in the future as installers gain experience and training.

Outreach Activities. NYSERDA provides a brief program summary on its Web site and in some consumer brochures, but it does not market this program directly. Rather, an outreach and education program is part of AstroPower's contract with NYSERDA. AstroPower contracted with NY Shines, an independent, nonprofit, public educational program conducted by Pace University School of Law Energy Project. The mission of NY Shines is to promote grid-tied photovoltaics to New York State homeowners through media advertising, workshops and seminars, brochures, exhibits, and other promotional activities. In addition to promoting the rebate and buy-down opportunities, NY Shines provides information about the Energy \$mart ${ }^{\mathrm{sM}}$ Loan program, net metering, and the state's tax credit for residential PV systems. NY Shines has guided more than 1,000 potential customers to vendors through referrals. NY Shines partners with local colleges, environmental education centers, county legislatures, cooperative extension services, and the folk music community to educate consumers about solar electric technology and its benefits. Beginning in 2002, NYSERDA contracted directly with NY Shines to conduct outreach and education.

In addition, a variety of advocacy groups, such as the Natural Resources Defense Council, are aware of all the NYSERDA's renewable energy programs through their participation in the program's advisory group. 


\section{Program Results}

As of the end of 2001, after more than two years in operation, 34 systems have been installed. Most of these systems were installed in 2001, but more than double this number is planned for the summer of 2002 alone. The program got off to a slow start in 1999 due to difficulties in gaining utility approval for interconnecting the PV systems. As activity began to pick up, the program faced an additional obstacle when the Xantrax-Trace SW series inverter was delisted by Underwriters Laboratories. Table 13 provides the number and combined size of systems installed under the program, as well as total funding provided.

Table 13: New York Residential Photovoltaics Program Results*

\begin{tabular}{|c|c|c||}
\hline Distributor & \# of Systems & Combined Size \\
\hline AstroPower & $20(30$ planned $)$ & $40 \mathrm{~kW}(60 \mathrm{~kW}$ planned $)$ \\
\hline SunWize & 14 installed $(39$ planned $)$ & $30 \mathrm{~kW}(85 \mathrm{~kW}$ planned $)$ \\
\hline \hline Total & $\mathbf{3 4}(\mathbf{6 9}$ planned $)$ & $70 \mathrm{~kW}(145 \mathrm{~kW}$ planned $)$ \\
\hline
\end{tabular}

* 1999 - May 2002; data not available by year.

SunWize has installed 14 systems to date and has orders for an additional 39-all of which are scheduled for installation by the end of summer 2002. SunWize projected that its program would result in 100 systems, totaling $100 \mathrm{~kW}$. The 53 systems installed or scheduled for installation are nearly two times larger than anticipated, with a total installed capacity of $115 \mathrm{~kW}$. AstroPower has installed 20 systems thus far, with approximately 30 more systems slated for installation by the end of July 2002. The installed capacity is also estimated at more than $100 \mathrm{~kW}$. NYSERDA is adding funds that will provide incentives for another 40 to 45 systems, with an installed capacity of 80 to $90 \mathrm{~kW}$, under the SunWize and AstroPower agreements.

\section{Observations and Lessons Learned}

The buy-down and rebate offered through individual distributors is just one component of the state's overall PV market-development strategy. The buy-down incentive component is poised to play a significant role in stimulating the state's PV market. However, only 34 homeowners have benefited from the program during the past two years despite tremendous public interest at promotional events. Surprisingly, residents have chosen to install systems twice the size of that initially anticipated by the participating distributors. The key factors influencing the effectiveness of the buy-down programs are discussed below in terms of program design and implementation, infrastructure issues, complementary financial incentives, and other influences.

Program Design and Implementation. Elements of the buy-down component that appear to enhance its effectiveness are the buy-down amount, partnership with PV dealers to market and administer the incentive, and outreach activities. However, perhaps the most significant feature of the buy-down incentive that contributes to its effectiveness is the fact that the buydown is part of a broader scope of activities designed to create a sustainable residential PV market. Limitations to the program include some challenges with the administrative mechanism and the uncertainty in funding duration. 
Funding Amount and Duration. The Residential PV Program's \$3 per-watt incentive can save participants up to $\$ 7,500$ in equipment and installation costs. This level of incentive, which is average among rebate/buy-down programs, is considered adequate by most observers interviewed. Some acknowledged that a higher incentive would be preferable at this early stage in market development; and that, with time, the incentive could be phased out. Uncertainty in funding for the program beyond the end of 2002 is a potential weakness.

Partnerships with Distributors. A unique aspect of this program - and a potential strengthis the fact that it is administered by the dealer networks of two PV distributors. This mechanism is a critical element in building a strong infrastructure, according to those interviewed. Since the distributors are in the business of making and selling PV systems, they are in an excellent position to market the program, train installers, and educate consumers. The distributors and dealers have a stake in making the program successful because they have made an investment to build the market.

The Residential PV Program is considered to have been most effective at providing the incremental economic benefit to those homeowners who have had long-standing interest in installing a solar-energy system. The program has the potential to be an effective means to encourage residents to install $\mathrm{PV}$, but it currently has only a minor impact on the market because of interconnection problems.

The primary disadvantage to the program's design is the absence of a mechanism for other PV suppliers to participate after the initial contracts were awarded. As a result, consumers are limited in their choice of equipment and installers. While choice is preferable on one hand, the lack of uniformity between the rebate and buy-down options may be confusing to consumers and poses difficulty in promoting the incentive as a statewide program. Providing details of the SunWize and AstroPower programs at a central source, such as the NYSERDA Web site, may help clarify the options. A follow-up program to involve other dealers was not pursued because of the difficulties encountered in gaining utility approval for interconnection; this is a significant problem, which will be discussed in the next section. NYSERDA's program administrator noted that the agency was hesitant to generate interest and then have consumers "run into a brick wall" with interconnection problems. Furthermore, installers may vary in the quality and amount of information they provide to customers regarding other available incentives, permitting issues, and the interconnection and net-metering process relative to a state-run program in which more uniform information may be available.

Holistic Approach. A buy-down alone is not sufficient; it is critical that complementary policies and programs are in place to develop a sustainable market. The program administrator underscored the fact that the rebate is but an initial step in the overall evolution of the Residential PV Program. The program was, in fact, designed with the understanding that a holistic approach is necessary to build a sustainable market.

The Residential PV Program's next phase involves working with IREC and ISP to conduct installer training and certification programs. Past experience with federal tax credits and grant programs in the 1970s and 1980s has shown that creating a market stimulus such as the NY Residential PV program can overwhelm a fledgling industry infrastructure, resulting in poor-quality system components, design, and installations by untrained contractors. Early 
system failures are likely to discourage other customers from investing in renewables. Some stakeholders interviewed advocated a solar-specific license requirement for PV installers to ensure quality and safety. It is likely that future incentive programs would require installers to be trained according to national or regional standards to ensure quality installations.

Furthermore, the partnership with housing developers to incorporate PV into Energy Star Homes will enhance the visibility of the program and provide demonstration opportunities. Focusing on the construction market can help homeowners overcome the high up-front costs by encouraging them to incorporate the cost of the PV system into their mortgages, assuming lending institutions are educated about the benefits of renewable energy systems.

Outreach. These coordinated programs, in coordination with NY Shines, are vital pieces in a sustainable market structure. Several stakeholders emphasized that claims regarding the costs and benefits of the technology need to be realistic. Too often, according to some interviewees, consumers have unrealistic expectations of the energy savings relative to the cost of the systems.

Infrastructure Issues. By far, the most significant factor reducing the program's effectiveness is the protracted and cumbersome interconnection approval process, according to the stakeholders interviewed. While all interviewees agree that safety and quality must be assured, they argue that the technical requirements in New York are excessive relative to standards required in other states. The additional testing and administrative obstacles utilities place on installations have limited the program's impact on the market as a result. One installer reported that she curtailed her efforts in upstate New York as a result of the repeated conflicts with utilities and began to focus on the Long Island market instead. Observers noted that early adopters, too, have been discouraged by the experience and are likely sharing their story with other potential customers.

The Xantrax-Trace inverter delisting in the fall of 2001 resulted in a further setback despite NYSERDA's and the dealers' proactive attempts to mitigate the problem. The program administrator, installers, and renewable energy advocates all underscore the need for a streamlined interconnection process to be in place to complement any financial incentive program. NYSERDA, as well as the state's Public Service Commission, and the renewable energy industry must coordinate efforts to reach a workable agreement with utilities over this issue.

Complementary Financial Incentives. Participants in the Residential PV Program can take advantage of several other complementary financial incentives - a tax credit, a low-interest loan, net metering, and a property-tax exemption. The extent to which these incentives actually work in concert with the Residential PV program varies.

Tax Credit. The $25 \%$ tax credit of up to $\$ 3,750$ for residential PV works in concert with the buy-down incentive. Tax data suggest that even more residents claim the credit than have participated in the buy-down program.

Loan Program. Few program participants have taken advantage of the Energy $\$$ mart ${ }^{\mathrm{SM}}$ Loan program, despite a $4.5 \%$ buy-down of the market interest rate. Some stakeholders reported that customers were unable to find a participating bank that would lend to homeowners. The 
Residential PV Program administrator is considering developing a low-interest financing package in partnership with a single lending institution. To facilitate "one-stop shopping," homeowners would work directly with the PV installer to apply for the loan.

Net Metering. New York's net-metering law applies to residential PV systems of $10 \mathrm{~kW}$ or less and enhances the financial benefits offered by the buy-down and other incentives. However, difficulty securing interconnection agreements with utilities has prevented customers from realizing immediate benefits from the net-metering policy thus far.

Property-Tax Exemption. While the property-tax exemption, which is equal to the increase in assessed value attributable to a solar or wind energy system, clearly has some financial benefits for program participants, it is not promoted - and most stakeholders were unaware of it. No information is made available to potential participants, and the information does not appear on the program Web site. Program participants often learn about the exemption after installation. Potential consumers should be made aware of this additional financial incentive for inclusion in the overall economic analysis of a project.

Other Influences. Beyond program-specific issues and policy influences, fear and philosophy are key factors that impact the level of participation. According to the stakeholders interviewed, homeowners who have taken advantage of the incentive program tend to be those who have been interested in renewable energy technologies for a long time. Concerns about electricity reliability, the energy crisis in California, the Middle East conflict, and, more recently, terrorist attacks have stimulated a greater interest in alternative energy. Although motivated by environmental responsibility, energy independence, or high-tech novelty, the availability of the rebate/buy-down appears to be the deal-maker for them. And certainly, some individuals choose to install PV systems regardless of financial incentives.

On the other hand, the economics of investing in PV for most homeowners-even with the package of incentives available in New York - may not be attractive enough to stimulate more deployment. High costs, together with the frustration over interconnection, are strong deterrents to investing in photovoltaic systems. However, some stakeholders argue that increased awareness and education can overcome what is often perceived to be a financial barrier. 


\section{APPENDIX C: LOAN-PROGRAM CASE STUDIES}




\section{Summary of Findings}

Iowa's Alternate Energy Revolving-Loan Program has the potential to play a supporting role in stimulating renewable energy development within the state. The revolving-loan construct is an excellent design for funding renewable energy development. This type of loan design does not rely on annual funding that could be removed without notice, which could suddenly deplete or end the loan program. The AERLP attracted too many participants early on, when the state's renewables set-aside policy was in place. Since then, however, participation has dropped off; and the program is currently underutilized. The program has supported a total of 22 residential, commercial, school, and independent power producer projects - primarily wind and biomass. Factors discouraging renewable energy development in general include a weak infrastructure for small-scale solar applications, difficulty securing bank financing for small projects or power purchase agreements for larger ones, and insufficient public awareness about renewable energy technologies and existing incentives.

The program's strengths include:

- attractive loan terms with low interest rates;

- the leveraging of funds through partnerships with private lending institutions;

- a sense of adequate program endurance, due to the nature of the revolving-loan program; and

- assistance and expertise from Iowa Energy Center engineers that effectively boost the confidence of lending institutions and potential customers.

Limitations include:

- a minimal level of marketing and public education;

- relatively high equipment costs;

- an unwillingness of lending institutions to loan relatively small sums of money for renewable energy systems or projects;

- ongoing interconnection and net-metering difficulties; and

- a potentially tedious and complicated application process.

Educating Iowans about renewable energy in general, and the availability of the existing loan program and tax incentives, will be essential to expand the use of renewable energy. Increasing outreach to and partnerships with lending institutions to address concerns they may have about renewable energy technologies can assure that securing private financing is not the limiting factor in program participation. Given the financial barriers most potential participants face, additional financial incentives are likely to be necessary if equipment costs remain at current levels. A user-friendly utility interconnection process and an enforceable net-metering rule also are critical elements that act in concert with any financial incentive to encourage renewable energy adoption. 


\section{Program Overview}

Funding and Administration. In 1996, the Iowa Legislature created the Alternate Energy Revolving-Loan Program (AERLP) to encourage the development of alternate energy production facilities and small hydro facilities within the state. The AERLP is administered by the Iowa Energy Center at Iowa State University.

AERLP funding totals $\$ 5.9$ million, which was collected from Iowa's investor-owned utilities during a three-year period from 1995 to 1997. During this time, investor-owned utilities contributed to the AERLP .085 of 1 percent of their total gross intrastate operating revenues for those calendar years. This money is committed entirely for loan purposes; no funds were authorized for the administration or marketing of the program. The amount of money available for loans at a given point in time is a function of the rate of loan repayment. As loan payments are made, money revolves back into the loan program.

Eligible Technologies. Renewable resources eligible for AERLP funding include solarenergy production (active solar water heat, active solar space heat, solar-thermal electric, photovoltaics), wind, biomass (waste management, resource recovery, refuse-derived fuel, agricultural crop or residue, and wood burning), and small hydro facilities.

Originally, AERLP funds were set aside for specific technologies and/or sizes of facilities for a given loan cycle to ensure that funding was available for a variety of technologies within the state. This distribution requirement is not currently in effect, but could be reinstated if the AERLP begins to experience an increase in loan requests in the future. The percentages are as follows:

- $5 \%$ solar energy production;

- $10 \%$ small wind (20 kW or less);

- $15 \%$ small hydropower;

- $20 \%$ large wind (greater than $20 \mathrm{~kW}$ );

- $20 \%$ biomass (waste management, resource recovery, refuse-derived fuel, agricultural crop or residue, wood burning); and

- $30 \%$ open.

Eligible Applicants. The only group ineligible for the AERLP is the nonrate-regulated utilities sector (i.e., the state's municipal and cooperative utilities). The borrower need not be an Iowa resident as long as the project, or alternate energy production facility, is located within the state.

Incentive Amount and Terms. The AERLP provides 50\% of the total loan amount, up to a maximum of $\$ 250,000$, at a $0 \%$ interest for up to 20 years. The other $50 \%$ of the loan amount is provided by a private lender at the market interest rate. The lender is responsible for administering the entire loan. The borrower writes one check each month to the lender, who then credits the AERLP.

Application Process. The three-page application requires technical and financial information about the lender, project capital costs, annual operation and maintenance costs, annual benefits, and simple payback. After the Iowa Energy Center determines that an application is 
technically sound, the application is ranked by the project's simple payback calculation. Next, the loan applicant's lending institution reviews the application and a written opinion from the Iowa Energy Center describing the technical merit of the project. All necessary interconnection or sales agreements between the loan recipient and the utility must accompany the application. Applications for projects of more than $\$ 50,000$ are accepted four times per year, while applications for projects of less than $\$ 50,000$ are accepted year-round.

Outreach Activities. The legislature provided no funding for advertising and marketing the AERLP. However, the Iowa Energy Center has used general center activities to make information available. For example, the Center's Web site features an AERLP section ${ }^{24}$ providing program history, details, application information, and guidelines. This is the main source of program information available to the public. The program administrator also has responded to hundreds of inquiries about the program during the past six years.

The Iowa Energy Center also delivers presentations about its programs, including the AERLP, to various organizations within the state each year. Presentations have been made to bankers, school administrators, and various other organizations. Each year, the Iowa Energy Center has a booth at the Iowa State Fair, where information on the loan program is distributed. The Iowa Energy Center's newsletter, Perspectives, which is published several times a year, occasionally includes updates on the AERLP. In 1999, Perspectives highlighted the AERLP through a series of case studies of AERLP projects and a summary of program achievements. Occasional news releases and other educational activities sponsored by renewable energy organizations have provided additional promotion for the program.

\section{Program Results}

Twenty-two AERLP projects have been installed since 1996, as summarized in Table 14, and additional applications are currently pending. Overall, 63 loan applications have been received; of these, 50 applications are unique and 13 are resubmissions of previously submitted applications. Twenty-five of the 63 applications did not receive a loan under the program for a variety of reasons, including the inability to qualify for a bank loan, the inability to secure an interconnection or power sales agreement, or a decision not to move forward with the project. These same reasons could explain why an application might be resubmitted to the program.

Seven of the 22 projects are small-scale, on-site projects for residents or businesses. No applications for projects containing only a solar component have been approved under the AERLP, although two applications were submitted and then later withdrawn for technical and/or financial reasons.

The AERLP has disbursed more than $\$ 3$ million, and an additional $\$ 600,000$ is pending. The loan program has leveraged $\$ 27.5$ million during its five-year history. Each $\$ 1$ loaned has resulted in about $\$ 6$ in leveraged projects. 
Table 14: Iowa Alternate Energy Revolving-Loan Program Results*

\begin{tabular}{|c|c|c|c|c|c||}
\hline Technology & $\begin{array}{c}\text { \# of } \\
\text { Loans }\end{array}$ & $\begin{array}{c}\text { Annual } \\
\text { Generation } \\
\text { (MWh) }\end{array}$ & $\begin{array}{c}\text { Total } \\
\text { Funding }\end{array}$ & $\begin{array}{c}\text { Project } \\
\text { Costs }\end{array}$ & Recipients \\
\hline Hybrid** & 2 & 75 & $\$ 54,000$ & na & $\begin{array}{c}\text { 1 Resident; } \\
1 \text { Resident/Small Business }\end{array}$ \\
\hline Solar & 0 & 0 & 0 & 0 & None \\
\hline Small Hydro & 1 & 2,860 & na & na & na \\
\hline Small Wind & 4 & 115 & $\$ 25,500$ & na & 1 Farmer; 1 Resident \\
\hline Large Wind & 7 & 8.345 & $\$ 1.3 \mathrm{M}$ & na & $\begin{array}{c}\text { 4 Schools; } \\
\text { Independent Power } \\
\text { Producers }\end{array}$ \\
\hline Biomass & 8 & 153,000 & $\$ 1.34 \mathrm{M}$ & na & $\begin{array}{c}1 \text { Resident; } \\
4 \text { Independent Power } \\
\text { Producers; 2 Businesses }\end{array}$ \\
\hline \hline Total & $\mathbf{2 2}$ & $\mathbf{4 7 7 , 2 3 5}$ & $\mathbf{\$ 3 , 2 7 4 , 4 3 5}$ & $\mathbf{\$ 2 0 . 5} \mathbf{M}$ & $\mathbf{2 2}$ \\
\hline
\end{tabular}

* September 1996 - December 2001.

** Hybrid systems include a combination of technologies, which could include photovoltaics, solar hot water, small wind, small hydro, and biomass.

na: not available

In 1996, during the first year of the AERLP, the renewables set-aside policy required investor-owned utilities to purchase power from renewable energy generators at the price of 6.02 cents/kWh. During this period, the Iowa Energy Center received more applications for funds than were available. In fact, three technically sound applications for projects were rejected because other projects were found to be more competitive based on formulas showing that other projects would have shorter paybacks. The following year, the 6.02 cents/kWh law was satisfied with the development of two large wind farms. Since then, no application for a project that is technically feasible (and which provides an adequate payback) has been denied a loan under the AERLP.

\section{Observations and Lessons Learned}

In general, the AERLP has experienced a modest level of participation during the initial five years. The program, which is not fully subscribed at the present, has the potential to provide a greater number of loans during the next five years of the program. The state's renewables set-aside policy generated initial interest and participation in the loan program. Stakeholders interviewed considered the AERLP, one of the few significant renewable energy incentives in the state, to be a worthy incentive that effectively supports the installation of new renewable energy production facilities in Iowa. The key factors influencing program effectiveness are discussed below in terms of program design and implementation, complementary financial incentives, infrastructure issues, and other influences.

Program Design and Implementation. Some of the key factors contributing to the AERLP's effectiveness involve the program's design and implementation features, including the incentive amount, funding security, quality assurance, and outreach. 
Incentive Amount. The AERLP's zero-percent interest rate for half of the project-financed cost is an attractive enticement-effectively reducing the loan's interest rate to half the market rate - and is available to a wide audience. For smaller projects, applications are accepted year-round, and the turnaround time for a submitted application is relatively short. The program administrator emphasizes that this level of responsiveness to prospective clients is critical to the success of the program.

Security of Funding. Furthermore, the nature of the revolving-loan program ensures that the funding source will continue to be available to other applicants. As loan amounts are repaid to the AERLP, that money "revolves back" and becomes available to fund new renewable energy projects. Whereas other types of incentives may be dependent on funding sources that could be reduced or eliminated depending on budget shortfalls, the revolving-loan fund is exempt from such uncertainty.

Quality Assurance. Through its coordination with local lending institutions during the application process, the AERLP educates loan officers about renewable energy technologies. With the surety that the Iowa Energy Center engineers evaluate the technical merits of an application to determine the likelihood of success and recovery of capital, lending institutions can feel more secure about participating in the program and providing renewable energy loans. This is a step in infrastructure development that can facilitate the deployment of renewable energy technologies in the state.

One homeowner stated that the lending process using the AERLP was smooth. The homeowner used the loan to purchase renewable energy technologies for his home. He explained that he and his wife were pleased when they stumbled across the loan as they researched renewable energy resources on the Web. The homeowner noted that the two or three installers that he contacted attempted to discourage him from using the loan by claiming that it would make the loan process too cumbersome. The installers did not offer to assist the homeowner in navigating the loan process. Despite the warnings from the installers, the homeowner was attracted to the loan-program terms of $0 \%$ interest on $50 \%$ of the cost of the equipment and installation costs during a 20-year period. The homeowner explained that the three-page application, which requires detailed technical and financial information, such as project capital costs, annual operation and maintenance costs, annual benefits, and simple payback, was entirely too difficult and burdensome for a homeowner. The AERLP Program Manager agreed that the homeowner had a difficult experience with the application because this homeowner's loan covered four renewable energy technologies, which made his application more difficult to complete than any other participant in the program. The homeowner found the IEC staff helpful and knowledgeable throughout the process. The homeowner said that most Iowans are not aware that the AERLP exists.

Outreach. The primary programmatic feature that may be limiting participation is the absence of market funds. All stakeholders interviewed agreed that the AERLP's major shortcoming can be attributed to the flawed enabling legislation, which precluded the use of any funds collected for administrative costs, including education and outreach. Because the segments of society that can most benefit from this incentive are largely unaware of its existence, the AERLP continues to be underutilized by its intended audience. 
Fortunately, legislation has been proposed that would permit interest earned from unspent AERLP funds to be used for program administration and promotion. Under the proposed legislation, the more AERLP money that is available for loans and thus earning interest, the more money would be available for AERLP administration and promotion. With these additional funds, the Iowa Energy Center could develop outreach and education materials targeting potential participants and coordinate these efforts with groups such as utilities, renewable energy-system installers, schools, advocacy organizations, and the corn-burning furnace industry.

Complementary Financial Incentives. Iowa offers other renewable energy incentives that can work in concert with the Alternate Energy Revolving-Loan Program. These include a renewable energy set-aside policy, a property-tax exemption, and a sales-tax exemption.

Renewable Energy Set-Aside. The program's early success can be attributed in part to the renewables set-aside policy in effect during the program's first year.

Property and Sales Tax Exemptions. Although the AERLP is one of several financial incentives available, the property-tax and sales-tax exemptions are neither well promoted nor well understood, even by some of those interviewed. The Iowa Department of Revenue and Finance currently does not keep detailed records on the use of these exemptions. While these incentives may not be as significant as grants and rebates available in other states, the savings associated with sales-tax and property-tax exemptions should certainly be examined and promoted. Given the lack of other significant financial incentives, the AERLP's low-interest financing is an important tool in expanding renewable energy deployment in the state.

Infrastructure. According to renewable energy advocates interviewed, the difficulties of interconnecting and net metering in Iowa are a major impediment to the installation of renewable energy systems. The net-metering law in Iowa, which has spent considerable time under litigation, only applies to investor-owned utilities and not to municipal and cooperative utilities.

Bank Financing. On the residential front, Iowa is witnessing an increase in the number of corn-burning furnaces purchased by homeowners and others. The AERLP can be used to finance corn furnaces. In fact, the Web sites of some of the corn-furnace manufacturers and distributors provide a link to the AERLP Web site. Corn furnaces often range from $\$ 2,000$ to $\$ 3,000$, and some banks refuse to partner with the Iowa Energy Center on such small loans when the lender's share would only amount to $\$ 1,000$ or $\$ 1,500$. This may discourage some homeowners from applying for an AERLP loan to finance the purchase of a corn furnace.

The AERLP and the Energy Bank have worked together to help several school wind turbine projects obtain low-cost financing. The AERLP, managed by the Iowa Energy Center, and the Energy Bank, managed by the Iowa Department of Natural Resources, have assisted schools in leveraging the Energy Bank's low-interest loan with the AERLP's zero-interest loan, resulting in savings of tens of thousands of dollars in interest costs. The Energy Bank's Program Manager explained that the compatibility of the two programs in offering lowinterest and no-interest loans, together with savings attributed to net metering and reduced utility costs, result in school projects that pay for themselves during the project life. 
Other Influences. Beyond program-specific issues and policy influences, there are other market and attitudinal factors that impact the adoption of renewables. Stakeholders interviewed identified high equipment costs and a lack of public awareness as the primary factors that discourage investment in renewables.

Even with the AERLP, the economics of investing in renewable energy technologies at the homeowner and small-commercial level may not be attractive enough to encourage these segments of the population to install renewable energy generating systems. Iowa is the $10^{\text {th }}$ windiest state in the nation; there are a number of large wind turbines generating renewable energy in the state. Support for wind in the state appears strong and opposition little. However, smaller wind-turbine equipment costs are still beyond many homeowners' and small businesses' financial means. Some speculate that incentive programs developed by other states, such as California's buy-down program, are seeing high levels of participation, thus increasing the demand for this equipment. Localized incentives can initiate an artificial demand of products that may lead to price increases elsewhere. Locations without comparable incentives may be penalized from the higher prices resulting from incentives elsewhere.

According to those interviewed, the high price of photovoltaic systems continues to discourage Iowans from installing this technology. Because Iowa's solar resources are relatively poor, the price of photovoltaic equipment will need to drop considerably before a widespread increase in the installation of photovoltaic systems will become a reality within the state.

\footnotetext{
* A survey was commissioned by the Iowa Department of Natural Resources in 2001 to determine the barriers to photovoltaic installations in six Midwestern states. The survey was distributed to engineers, realtors, developers, architects, contractors, and college instructors. The survey determined that "cost-effective systems were the most important component in making PV systems practical, followed by interconnection to the power grid, easy-to-use systems, and financial incentives for use."
} 


\section{Summary of Findings}

New York's Energy \$mart ${ }^{\mathrm{sM}}$ Loan is poised to play a supporting role in stimulating renewable energy investment in New York. The results of the program's first year indicate that many individuals, businesses, and others have benefited from the program with respect to energy efficiency improvements, but the program has yet to make an impact on the installation of renewables. The reluctance by banks to serve as partners in the loan program to finance small-scale renewables projects has limited its effectiveness thus far. If this problem is rectified, other state policies supportive of renewable energy technology can work in concert with the loan program to provide significant benefits, primarily for photovoltaics. These include a buy-down, tax credit, net metering, and property-tax exemption. Despite these incentives, high equipment costs and a costly, time-consuming interconnection process are cited as the chief reasons why more renewables projects are not under development in the state in general.

Strengths of the loan program include:

- a generous incentive of $4.5 \%$ below the market interest rate;

- the leveraging of funds through partnerships with private lending institutions;

- the incentive's compatibility with the NYSERDA Residential PV Program rebate, tax credit, and net-metering incentives; and

- the incentive's availability to all investor-owned utility customers.

The program's limitations include:

- inadequate quality assurance for PV systems early in the program;

- a lack of program awareness;

- an unwillingness of lending institutions to loan relatively small sums of money for renewable energy systems or projects; and

- a lack of coordination with the PV industry regarding details of the program.

Educating consumers about renewable energy technologies and the availability of low-cost financing will be a continual challenge, requiring partnerships and alliances for program success. Partnering with education and training institutions - and developing the industry infrastructure - can provide additional consumer outreach and promotion opportunities that go beyond the scope possible for the small-staffed loan program. The availability of complementary incentives should be widely promoted as a package in each program's marketing materials. For businesses, the green-building tax credit and loan program should be jointly promoted as well. A single agency with one or two staff members cannot administer and market the program adequately. Banks, renewable energy equipment vendors, contractors, and renewable energy advocates must be involved in the development and marketing of the program. 


\section{Program Overview}

Funding and Administration. The New York Energy $\$ \operatorname{mart}^{\mathrm{t} \mathrm{M}}$ Loan Fund is a component of the New York Energy \$mart ${ }^{\mathrm{SM}}$ program, a public-benefit program designed to lower electricity costs by encouraging the use of energy efficiency and renewable energy technologies. The Energy \$mart ${ }^{\mathrm{SM}}$ program, administered by the New York State Energy Research and Development Authority (NYSERDA), is funded by a system-benefits charge on the electricity transmitted and distributed by New York investor-owned utilities and paid for by electricity consumers. The loan program, funded at a level of $\$ 1.9$ million per year for five years, provides interest-rate reductions on loans from participating lenders.

The primary goal of the loan fund is to stimulate energy-efficient and renewable energy technology market development. The program seeks to demonstrate the economic advantages of implementing energy efficiency and renewable energy projects to financial institutions, equipment vendors, and customers. Financial institutions are encouraged to consider energy savings in determining the credit level for which borrowers qualify. Equipment vendors are encouraged to market premium energy-efficient equipment more aggressively and use the low-interest loan as a customer incentive. During the summer months, the program has emphasized opportunities to use the low-interest loan for peak load reduction strategies.

Eligible Technologies. The Energy \$mart ${ }^{\mathrm{SM}}$ Loan program only funds energy-related improvements. Eligible improvements fall into two categories: prequalified measures and custom improvements. Many energy efficiency projects prequalify for interest-rate reductions, including high-efficiency lighting, heat pumps, efficient heating and airconditioning equipment, Energy Star ${ }^{\circledR}$ windows and appliances, weatherization measures, occupancy controls, and energy-management systems. Renewable energy projects automatically qualifying for interest-rate reductions include solar hot water and heating, photovoltaics, and small wind generators. Any improvements not included on the list of prequalified measures require preapproval. Such custom improvements ${ }^{*}$ must meet payback, technical approval, and other criteria.

Eligible Applicants. Eligible borrowers may be from any sector of utility customercommercial, industrial, retail, agricultural, nonprofit, institutional, residential, or multifamily. Applicants also must be electric distribution customers of one of the state's six investorowned utilities: Central Hudson Gas \& Electric Corp., Consolidated Edison Company of New York, Inc., New York State Electric \& Gas Corporation, Niagara Mohawk Power Corporation, Rochester Gas \& Electric Corporation, and Orange and Rockland Utilities, Inc. Applicants receiving incentives through other New York Energy $\$$ mart ${ }^{\mathrm{SM}}$ programs also may receive interest-rate reductions for eligible projects.

Although photovoltaics is a prequalified technology, residential customers must meet additional requirements. During the first six months of the program, loans were approved for homeowners who elected to install PV systems on their own. However, the first one or two of these systems were installed improperly. To ensure quality installations, the program administrator began to require participation in New York's Residential PV Program (see case study on page 80) to qualify for the loan program. Participants in the Residential PV Program

\footnotetext{
* One- to four-family residential customers are not eligible for interest-rate reductions on loans for custom improvement projects.
} 
purchase systems through one of two approved contractors who install the systems, monitor performance, and offer rebates.

Incentive Amount and Terms. The New York Energy \$mart ${ }^{\mathrm{SM}}$ Loan Fund provides interestrate reductions of $4.5 \%$ below market rate on loans for energy-saving improvements and renewable energy technologies. Loans of up to $\$ 500,000$ are available through participating lenders. Multifamily projects (more than four units) can qualify for a loan of up to $\$ 5$ million.

Application Process. Interested borrowers complete and submit an application form, a prequalified measures worksheet and technical documentation, and the lender's loan documents to a participating financial institution. The financial institution then completes the lender information and submits the package to NYSERDA for approval. Custom improvements must go through a preapproval process and receive a notice of project preapproval before submitting the application. In exchange for the participating lender's agreement to charge the borrower a reduced interest rate on the approved loan amount, NYSERDA provides the lender with a one-time lump sum payment representing the difference between the lender's interest rate and the reduced interest rate.

When installation is complete, the borrower submits a "Certificate of Project Completion" to NYSERDA and to the lender. NYSERDA has a policy of post-installation follow-up visits to ensure that the improvements have been installed consistent with the application. However, no such inspections have taken place to date due to inadequate staff resources.

Outreach Activities. The loan-program administrator provides equipment vendors, banks, economic development agencies, and other NYSERDA programs with brochures, loan applications, and other marketing materials. The program coordinates information sharing with other NYSERDA programs such as the New Construction Program ${ }^{*}$ and Flex Tech Program $^{\dagger}$. The program has focused some of its efforts toward economically depressed areas by partnering with independent development agencies. For participating lenders, NYSERDA will customize loan-program information with the bank's logo, provide and fund newspaper advertisements, and provide marketing materials.

In addition, NY Shines, an independent, nonprofit, public educational program operated by Pace University School of Law Energy Project, promotes grid-tied photovoltaics to New York State homeowners through media advertising, workshops and seminars, exhibits, and other promotional activities. NY Shines provides information about the Energy $\$$ mart ${ }^{\mathrm{SM}}$ Loan program as well as the state's tax credit and rebate opportunities for residential PV systems. NY Shines has guided more than 1,000 potential applicants to vendors through referrals. NY Shines partners with local colleges, environmental education centers, county legislatures, cooperative extension services, and the folk music community to educate consumers about solar-electric technology and its benefits.

\footnotetext{
* The New Construction program provides technical assistance and cash incentives for cost-effective electricefficiency measures in new or renovated buildings.

${ }^{\dagger}$ Flex Tech services provide customized assistance for energy efficiency measures.
} 


\section{Program Results}

Table 15 provides the number, type, funding, combined size, and recipients of loan projects implemented under the Energy \$mart Program. As of the end of 2001, after about one year of operation, the loan program has provided about $\$ 1.2$ million in funding to leverage about $\$ 12$ million in loans for 260 energy efficiency projects and four PV installations. Homeowners have been the primary recipients of the loans, although commercial projects have received more total funding.

Table 15: New York Energy \$mart Loan-Program Results*

\begin{tabular}{|l|c|c|c|c|c|}
\hline \multicolumn{1}{|c|}{ Technology } & $\begin{array}{c}\text { \# of } \\
\text { Loans }\end{array}$ & $\begin{array}{c}\text { Combined } \\
\text { Size }\end{array}$ & Funding & $\begin{array}{c}\text { Project } \\
\text { Costs }\end{array}$ & Recipients \\
\hline PV & 4 & $8 \mathrm{~kW}$ & $\$ 10,000$ & $\$ 100,000$ & Residential \\
\hline $\begin{array}{l}\text { Energy } \\
\text { Efficiency }\end{array}$ & 260 & N/A & $\$ 1.19 \mathrm{M}$ & $\$ 11.9 \mathrm{M}$ & $\begin{array}{c}60 \% \text { Residential } \\
40 \% \text { Commercial }\end{array}$ \\
\hline
\end{tabular}

* December 2000 - December 2001

The Energy \$mart Loan program has benefited a variety of individuals, businesses, and other organizations who have implemented energy efficiency projects. Although there were no stated goals for the number of participants or energy savings at the program's outset, stakeholders agreed that attracting more than 260 participants in the program's first year is an excellent start. However, only a few loans have been used to finance renewables projects. The disparity in the number of loans for efficiency compared to renewables projects is not surprising given the relative lack of awareness of and longer payback for PV and wind systems.

Although data is not available from New York's PV tax credit program for 2001, 81 credits were claimed in 2000, with some presumably being carryovers from the previous year. Results from the buy-downs offered by SunWize and AstroPower as part of NYSERDA's Residential PV Program suggest that about 30 PV systems were installed in 2001. Thus, nearly all of these customers are using other financing methods or paying cash for their PV systems.

\section{Observations and Lessons Learned}

New York's Energy \$mart ${ }^{\mathrm{sM}}$ Loan is poised to play a supporting role in stimulating renewable energy investment in New York. The results of the program's first year indicate that many individuals, businesses, and others have benefited from the program with respect to energy efficiency improvements; but the program has yet to make an impact on the installation of renewables. The key factors influencing program effectiveness are discussed below in terms of program design and implementation, complementary financial incentives, infrastructure issues, and other influences.

Program Design and Implementation. Program features that appear to contribute to the loan's effectiveness include incentive amount and duration, eligibility, and partnership with lending institutions. These partnerships also have limited participation in some cases. 
Inadequate communication with vendors and installers also is considered to detract from the program's effectiveness.

Incentive Amount and Duration. The $4.5 \%$ interest-rate reduction provides significant savings over the life of the loan. As interest rates declined throughout 2001, some participants received loans with interest rates approaching $0 \%$. These savings, together with New York's relatively high electricity costs, make investing in energy efficiency improvements cost-effective in many circumstances. It's a win-win-win situation for customers, vendors, and banks alike.

Eligibility. Offering the interest-rate reductions to a wide variety of eligible sectors allows virtually any investor-owned utility customer to take advantage of the loan program.

Partnership with Lending Institutions. Partnering with a network of lending institutions takes advantage of this sector's experience with project financing, reduces NYSERDA's administrative costs, and increases awareness of the benefits of energy efficiency and renewable energy technologies among lending officers. At first, most banks were reluctant to participate because a new program requires additional resources and training. Furthermore, the benefits were uncertain. Early adopters tended to be small banks with the versatility to implement new programs that viewed participation as a way to gain market advantage. Now, many banks are enthusiastic about the program and have applied to participate. There are now more than 60 lenders associated with the loan program. This relationship can help foster acceptance of clean technologies among lending institutions, providing consumers with easier access to low-cost financing for renewables.

On the other hand, loan applications for renewables are limited by a lack of coordination with equipment dealers and installers, and the difficulty residential customers have in finding a participating bank that will finance homeowner projects. Several observers noted that some residents interested in an Energy $\$$ mart $^{\mathrm{SM}}$ Loan could not find a participating lender who would provide a loan for residential PV projects early in the program. In fact, one PV installer stopped providing information on the loan program because of the frustration experienced by some of her clients in securing a loan for a residential project. Furthermore, the program administrator de-emphasized renewables in the program's marketing materials once participants were required to participate in the Residential PV Program, assuming that these additional requirements would deter potential borrowers. As the program matures and more banks are willing to finance homeowner projects, it is critical that updated promotional materials and financing information - including some examples portraying the advantages of low-interest financing - be shared with the renewable energy industry.

Complementary Financial Incentives. In addition to the Energy $\$$ mart ${ }^{\mathrm{SM}}$ Loan, New York offers a host of incentives that encourage the installation of photovoltaics, but few for wind systems. A Green Buildings tax credit, a residential PV tax credit and buy-down, cash incentives for incorporating high-efficiency and renewable energy equipment into new construction, net metering for residential PV, and a property-tax exemption all make investing in renewables more attractive than just a couple of years ago. While the propertytax exemption, which is equal to the increase in assessed value attributable to a solar or wind energy system, clearly has financial benefits for program participants, it is not promotedand most stakeholders were not aware of it. If NYSERDA chooses to enhance its outreach 
and marketing efforts to generate more interest in the loan program for renewables, it would be important to promote these complementary incentives as a package.

Infrastructure. As discussed in the previous case studies on New York's tax-credit and buydown programs, the primary policy issue that appears to be discouraging or delaying the installation of grid-tied renewables in general is the lack of a simple and standardized utilityinterconnection process.

Other Influences. Stakeholders interviewed identified public concerns about energy security, a desire to reduce dependence on utilities, and high electricity costs as the primary external influences that stoke interest in renewable energy technologies. However, stakeholders agreed that even with the low-interest loan, the economics of investing in renewable energy technologies at the homeowner and small-commercial levels still may not be considered attractive enough to stimulate more deployment. Financial barriers, together with the difficulties associated with interconnection, appear to limit investments in renewable energy technologies unless individuals and businesses are strongly motivated by noneconomic factors. Few systems have been installed during the past year. Of those that have been installed, some are financed using other mechanisms or are purchased outright.

With respect to energy-efficient equipment, inadequate availability of premium energy efficiency products may be limiting program participation. According to the program administrator, vendors appear to be resistant to selling high-end energy efficiency equipment. 


\section{Summary of Findings}

Oregon's Small-Scale Energy Loan Program (SELP) has assisted in the adoption of about 530 energy efficiency and renewable energy technologies in both the public and private sectors during the past 21 years. The state's residential and business tax credits are important incentives that work in conjunction with the SELP. Municipalities and nonprofits implemented over a third of the projects SELP has financed; businesses comprise just more than a quarter of loan participants, and residents make up about $20 \%$ of the participants. However, residential solar hot-water and geothermal systems account for the majority of loans for renewables. Stakeholders interviewed considered the SELP to be a major driver in the development of some large commercial/industrial renewable energy projects - primarily hydro and biomass - but agreed that it may be less effective at stimulating residential-scale projects despite the fact that most renewable energy projects are relatively small. With more than 20,000 residential and 500 commercial/industrial renewable energy systems in the state, it is evident that only a handful of individuals and small businesses installing these systems use the SELP.

The program's strengths include:

- a high level of available funding and loan flexibility due to the convenient, in-house lending structure provided by the Oregon Energy Office;

- the incentive's role as part of the state's holistic approach to energy resource management;

- the availability of complementary tax incentives and the inclusion of this information by the Energy Office on the SELP application; and

- the ability of applicants to bundle energy efficiency improvements with the installation of renewable energy technologies.

Limitations include:

- an insufficient interest-rate reduction and substantial loan fees;

- insufficient marketing and outreach in the residential and small-business sectors; and

- competition from more attractive loans and rebates offered by various Oregon utilities.

The Office of Energy has considered a revolving-type loan fund to provide a better vehicle for smaller loans. As the loan program builds up equity, there may be an opportunity to offer loans as low as 3\% interest to the residential sector or other niche markets. The state's recently established public-benefits fund could be another source of funds for initiating such a program as well as other complementary programs.

\section{Program Overview}

Funding Administration. In 1980, Oregon voters approved an amendment to the Oregon State Constitution authorizing the sale of bonds to finance small-scale energy projects within the state." The following year, the SmallScale Energy Loan Program (SELP) was created. The SELP's funding source is unlike that of other loan programs, which usually draw from

\footnotetext{
* Oregon is the only state with a provision in the federal tax law allowing it to sell tax-exempt bonds.
} 
revolving, oil overcharge, or public-benefits funds. Instead, to fund the SELP, bonds are sold periodically and on an "as-needed" basis. The maximum amount of bonds that can be sold biennially is $\$ 100$ million, although this amount has never been issued. The current loan portfolio amounts to approximately $\$ 150$ million.

The SELP is administered by the Oregon Office of Energy (OROE) and is available for instate projects that save energy, produce energy from renewable resources, use recycled materials to create products, or use alternative fuels. Approximately 10 staff members work on the loan program. Staff responsibilities include accounting, loan underwriting and documentation, portfolio management, bond sales, project review and engineering analysis, marketing, and administration.

Eligible Technologies. Renewable resources eligible for the SELP include passive solar space heat, active solar-water heat, active solar-space heat, solar-thermal electric, photovoltaics, wind, biomass, hydroelectric, renewable transportation fuels, geothermal, cogeneration, and waste heat recovery.

Eligible Applicants. Loans are available to residents; businesses; schools; local, state, and federal agencies; public corporations; electric cooperatives; tribes; and nonprofits.

Incentive Amount and Terms. The SELP offers low-interest, fixed-rate, long-term loans for qualified projects. The loan rate is fixed and varies depending on the type of borrower and project, and market bond rate. Tax-exempt funds can be used for larger renewable projects. In early 2002 , the interest rate was $6.5 \%$ for small solar projects using taxable funds, and loan terms usually ranged from 10 to 15 years. The term of the loan cannot exceed the life of the project.

Application Process. The OROE administers all aspects of the SELP; no outside lending institutions are involved. The agency recommends that customers schedule a preapplication meeting prior to submitting a loan application. By discussing customers' energy project ideas with them early in the development of the project, the staff is able to suggest energy-saving ideas and technologies, as well as different types of assistance the agency can provide.

The borrower pays all loan-program expenses. Program fees include: (1) an application fee of $0.1 \%$ of the loan amount with a $\$ 2,500$ maximum; (2) an underwriting fee, which is $0.5 \%$ of the loan amount, with a $\$ 500$ minimum and $\$ 5,000$ maximum; and (3) a loan fee of $1.0 \%$ of the loan amount. However, the underwriting fee less $\$ 500$ will be applied toward the loan fee at closing. These fees can be cost-prohibitive for small projects, so the total fees on renewable project loans of less than $\$ 20,000$ are capped at $\$ 500$.

The time necessary to approve a project is generally determined by the loan amount requested. Smaller residential loan applications are usually approved in a day or two, while larger projects require additional time for approval. In general, loan applications of less than $\$ 100,000$ received from a public agency can be processed in three weeks. Commercial loanprocessing time frames range from a few weeks for smaller loans to several months for larger loans. If a large project requires the sale of bonds, additional time is required. Loan requests of more than $\$ 100,000$ must be reviewed by a Citizen Advisory Committee, a group of seven individuals appointed by the agency director. 
Although the SELP currently has no stated requirements for performance criteria, equipment certification, or contractor licensing, the design aspects of all projects are reviewed by the SELP's technical project staff prior to approval of the loan. Owners may construct their own projects as long as the projects meet the state electrical code-used equipment is permitted.

State contractor-licensing requirements are being developed. During the 2001 legislature, a law was passed requiring the licensing of all installers of solar hot-water and photovoltaic systems. The Building Codes Division of the state has issued interim licensing rules while the final rules are being completed.

Outreach Activities. The Office of Energy promotes the SELP and other programs on its Web site, in workshops and conferences, through information provided to utilities, and by advertising via journals and radio. Target audiences have included the League of Counties and Cities, schools, American Institute of Architects, energy-saving performance contractors, rural farmers, and utilities. The SELP program Web site includes detailed program and contact information, including an energy-loan brochure, a Q\&A fact sheet, examples of eligible projects, loan-program rates, a loan-fee schedule, a loan calculator, loan applications, and case studies of projects that have been constructed using the SELP. Some renewable energy vendors and installers used the program as a marketing tool as well.

\section{Program Results}

From 1981 to 2000, more than 813 loan applications were submitted to the Office of Energy. Of those applications received, more than 540 loans requesting $\$ 309.7$ million were approved, and about 530 loans for more than \$290 million have been closed - an average of more than $\$ 14$ million per year. Table 16 provides the number, technology, total funding, energy saved/produced, and loan recipients for projects implemented under the SELP.

Approximately two-thirds of the loans were used to finance energy efficiency projects. Of the $33 \%$ of loans issued for renewable energy projects, most were for small residential solar water-heating or geothermal systems, while six were for PV systems. Larger commercial/industrial projects included hydroelectric, biomass, and geothermal systems. Overall, about $20 \%$ of the loans have been disbursed to residents, $28 \%$ to businesses, $38 \%$ to municipalities and nonprofits, and the remaining to state agencies.

In 2000 and 2001, the majority of loans continued to support conservation measures. Applications for residential and farm projects have increased to $30 \%$. The number of residential solar projects in the \$20,000-30,000 range has increased recently, as well as combined wind and solar systems. Grid-connected systems also are on the rise. The flow of business applications has remained constant, but an increasing number of industrial loans are being issued, presumably due to the recent spike in electrical rates. Government applications have declined. Overall, the number of applications received by the Office of Energy increased by $30 \%$ in 2001 . 
Table 16: Oregon Small-Scale Energy Loan-Program Results*

\begin{tabular}{|c|c|c|c|c|c|}
\hline Technology & \# of Loans & Recipients & $\begin{array}{c}\text { Total } \\
\text { Funding }\end{array}$ & $\begin{array}{c}\text { Annual Energy } \\
\text { Saved } \\
\text { (MMBTU) }\end{array}$ & $\begin{array}{c}\text { Annual } \\
\text { Generation } \\
\text { (GWh) }\end{array}$ \\
\hline Hydro & 29 & $\begin{array}{l}20 \% \text { residential } \\
80 \% \text { other }\end{array}$ & $\$ 101,814,201$ & - & 232.073 \\
\hline Conservation & 350 & & $\$ 111,157,746$ & $2,320,857$ & - \\
\hline Solar Heat & 49 & $\begin{array}{l}90 \% \text { residential } \\
10 \% \text { other }\end{array}$ & $\$ 820,735$ & $4,247.03$ & - \\
\hline Photovoltaics & 7 & $\begin{array}{l}85 \% \text { residential } \\
15 \% \text { other }\end{array}$ & $\$ 508,731$ & 56.89 & 0.061 \\
\hline Geothermal & 78 & not available & $\$ 23,132,961$ & $41,644.80$ & - \\
\hline Biomass & 16 & $\begin{array}{l}12 \% \text { residential } \\
88 \% \text { other }\end{array}$ & $\$ 53,141,248$ & 864,602 & 201.172 \\
\hline Wind & 1 & & $\$ 23,600$ & - & 13.300 \\
\hline Total & 530 & & $\$ 290,646,917$ & $3,231,408$ & 446.606 \\
\hline
\end{tabular}

* $1981-12 / 31 / 00$

\section{Observations and Lessons Learned}

Oregon's Small-Scale Energy Loan Program (SELP) has assisted in the adoption of about 530 energy efficiency and renewable energy technologies by both the public and private sectors during the past 21 years. Although the majority of loans support municipality, nonprofit, and commercial projects, residential solar hot-water and geothermal systems account for the majority of loans for renewables. With more than 20,000 residential and 500 commercial/industrial renewable energy systems in the state, it is evident that only a handful of individuals and small businesses installing these systems use the SELP.

The key factors impacting program effectiveness are discussed below in terms of program design and implementation, complementary financial incentives, infrastructure issues, and other influences.

Program Design and Implementation. The primary features that are considered to enhance program effectiveness include the program's in-house lending structure, the energy office's integrated approach to energy resource management, and partnerships. The program's limited impact on the overall deployment of small-scale systems has been attributed to the minimal interest rate reduction relative to private lending arrangements, loan fees, availability of other sources of credit and financing for small loans, and minimal marketing directed toward the residential sector.

Incentive Amount and Terms. Stakeholders interviewed considered the SELP to be a major driver in the development of some large commercial/industrial renewable energy projectsprimarily hydro and biomass - but agree that it may be less effective at stimulating residential-scale projects despite the fact that most of the renewable energy projects are relatively small. The program name is a bit misleading in that the program is more often costeffective for larger projects. The Office of Energy explained that the SELP's loan program fees can be absorbed easily by a larger project, but may prove too expensive for smaller 
projects. Furthermore, the interest rate may be only marginally better than what borrowers for small projects can achieve through private lenders. A small interest-rate reduction on a larger loan can have a larger impact. In addition, if a renewable project is large enough, the borrower may be eligible for tax-exempt bond rates. Moreover, other credit and financing vehicles, some of which are offered by utilities, are available for small loans.

The Office of Energy has considered a revolving-type loan fund to provide a better vehicle for smaller loans. As the loan program builds equity, there may be an opportunity to offer 3\% to the residential sector or other niche markets. The state's recently established publicbenefits fund could play a role in initiating such a program. One current potential partnership is with Oregon Rural Action, a group in Eastern Oregon seeking to develop on-site generation. SELP officials will be working with this group to offer support and try to expand renewable energy in this market.

Funding Structure. All aspects of the SELP program, including lending services, are administered through the Oregon Office of Energy. Managing all aspects of the loan program in-house has improved program effectiveness, according to program administrators. By following the loan process from start to finish, the technical, administrative, and financial aspects of the loan can be addressed together. Program administrators maintain contact with applicants to inform them of the status of their loans. Furthermore, additional flexibility exists; loans can be expedited to meet certain circumstances.

Integrated Approach. By funding a combination of energy conservation and renewable energy projects, the SELP encourages an integrated approach to saving energy and resources. It is advantageous to the consumer to be able to finance improvements in energy conservation and renewable energy using one loan. Technologies such as air handling, envelope, lighting, weatherization, solar heating, wind power, and biomass, to name a few, can be used in a holistic way to optimize energy savings. Such an approach may or may not be presented to the customer by a vendor or installer.

Partnerships. Partnerships play a critical role in educating the potential participants in Oregon's energy programs. Partnerships that have been valuable to the SELP programs include those with renewable energy and conservation equipment vendors and installers, utilities, and engineering and architectural firms.

Outreach. One solar installer commented that the SELP is not marketed vigorously to the residential and small-business sectors, which are generally unaware of the availability of the SELP. However, the Office of Energy has recently begun targeting the residential and farm sectors through vendors and business groups. As a result of these marketing efforts, the program has witnessed an increase in the number of applications submitted and loans issued for smaller projects.

Complementary Financial Incentives. The availability of complementary tax incentives in Oregon is considered to enhance program effectiveness. Inconsistently implemented netmetering rules in the state may deter some renewable energy development, but net metering can be a valuable incentive for grid-connected technologies. Some factors that may deter renewable energy development include the implementation of net-metering rules within the state and uncertainties associated with restructuring. More attractive loan programs for 
residential solar hot-water systems offered by a number of utilities also may limit participation in the SELP.

Tax Credits. Many projects funded by the SELP also are eligible for the Business Energy Tax Credit (see case study on page 50) or the Residential Energy Tax Credit (see case study on page 56). According to the Office of Energy, a majority of loan recipients who apply for the loan also apply for a state tax credit. By providing information about the state's available tax credits on the SELP application, the Oregon Office of Energy is encouraging borrowers to investigate their eligibility for these incentives.

Utility Programs. Attractive loan and rebate packages are available through a number of utilities in Oregon. For example, the Eugene Water and Electric Board (EWEB), Emerald Public Utility District, Ashland Electric, and others participate in The Bright Way To Heat Water program. For solar water and pool-heating systems, rebates of $\$ 600$ to $\$ 1,200$ are available in addition to zero-interest loans of up to $\$ 4,000$. In these districts, customers interested in solar water-heating systems have more attractive incentives through their utility than through the SELP.

Net Metering. Oregon's net-metering law allows net metering for customers with solar, wind, or hydropower systems of up to $25 \mathrm{~kW}$, although enrollment is limited to a total installed capacity of $0.5 \%$ of the utility's historical single-hour peak load. Stakeholders reported that the ease with which customers can establish net-metering agreements varies among utilities and that the utilities are still climbing the knowledge curve in this area.

Other Influences. Other influences that impact the use of RETC include the prevalence of pro-renewable energy attitudes in the state and the relatively high cost of renewables. Progressive attitudes toward environmental and energy conservation issues, together with an array of supportive renewable energy policies, have helped the state become one of the nation's leaders in solar installations. Policies encouraging renewables have been implemented despite the state's historically low electricity prices. Stakeholders reported that Y2K and recent price spikes in electricity costs have increased interest in renewable and energy-efficient technologies during the past few years in particular. Some observers noted a strong sense of "isolationist thinking" among some of the state's residents and a desire to live in close connection to the land. Oregon has a high level of activism among its renewable energy community, and there are a number of nonprofit organizations whose missions include the promotion of renewable energy. Oregon became the first state in the country to install photovoltaics on its capitol building in April 2002. 


\section{Appendix D: State Profiles}




\section{FLORIDA}

Florida is the $26^{\text {th }}$ largest state in terms of size, yet its population ranks fourth in the nation, and it consumes the third highest amount of electricity among U.S. states. Like New York, Florida's power generation base is diverse. Coal accounts for $36.3 \%$ of power generation, with natural gas (23.0\%), petroleum (19.9\%), and nuclear (16.9\%) also making significant contributions. Other resources $(3.9 \%)$ and hydro $(0.1 \%)$ account for the rest. ${ }^{*}$ The average retail price of electricity was 6.85 cents/kWh in 1999 , earning Florida $19^{\text {th }}$ place nationally in terms of most expensive rates among states. The average residential electricity cost was 7.73 cents/kWh in 1999; the average commercial electricity cost was 6.22 cents/kWh. ${ }^{\dagger}$

According to the Renewable Electric Plant Information System (REPiS) database, the installed renewable energy capacity of Florida's electric plants was $1,287 \mathrm{MW}$ in $2000{ }^{\ddagger}$ The state has strong biomass potential, with an estimated 13.9 billion $\mathrm{kWh}$ of electricity available. With good solar potential throughout the state, Florida lives up to its nickname- " The Sunshine State." However, wind and hydro resources are scant. ${ }^{\S}$ It is estimated that at least 140,000 solar-thermal systems and as many as 20,000 photovoltaic building systems may be installed in Florida by 2010. ${ }^{* *}$ The Florida Solar Energy Industries Association (FlaSEIA), a nonprofit professional association of companies involved in the solar-energy industry, estimates that approximately 650,000 solar installations are operational in the state. These solar installations include solar water heating, pool heating, and solar-electric systems.

As shown in Table 17 below, Florida offers a few incentives - in the form of a rebate and sales-tax exemption - to encourage the use of renewable energy.

Table 17: Selected Florida Renewable Energy Policies ${ }^{\dagger \dagger}$

\begin{tabular}{||l|l||}
\hline PV Rebate Program & $\begin{array}{l}\text { Rebates of } \$ 4 \text { per installed watt are available to all sectors. Maximum rebate is } \\
\$ 16,000 \text { for residential systems, and } \$ 40,000 \text { for commercial systems. }\end{array}$ \\
\hline Sales Tax & Solar energy equipment is exempt from the sales tax. \\
\hline Net Metering & $\begin{array}{l}\text { Net metering is optional under the interconnection rule. Several utilities have } \\
\text { established their own net-metering policies. }\end{array}$ \\
\hline Contractor Licensing & $\begin{array}{l}\text { A solar license is required for installing, maintaining, and repairing solar energy } \\
\text { equipment unless a contractor holds a license in a related area, such as plumbing } \\
\text { or electrical work. }\end{array}$ \\
\hline Solar Access & Covenants or ordinances that restrict the use of solar are forbidden. \\
\hline Equipment Certification & There are certification standards for solar energy equipment. \\
\hline Construction Standards & $\begin{array}{l}\text { The use of solar technologies in state buildings is required when economically } \\
\text { feasible. All new educational facilities must include passive solar design. }\end{array}$ \\
\hline
\end{tabular}

\footnotetext{
* State Electricity Profiles, Energy Information Administration, U.S. Department of Energy, 1999. Viewed at http://www.eia.doe.gov/cneaf/electricity/st_profiles/florida/fl.html.

${ }^{\dagger}$ Ibid.

$\$$ U.S. Department of Energy, Renewable Electric Plant Information System (REPiS) database, version 5.0.01, 2000. Viewed at http://www.eren.doe.gov/repis/database/repis5.cfm. Note that this figure includes only biomass, hydro, photovoltaics, and wind.

${ }^{\S}$ State Energy Alternatives, Energy Efficiency and Renewable Energy Network. Viewed at http://www.eren.doe.gov/state_energy/states_techresource.cfm?state=FL, June 13, 2002.

** PV Buildings Program Overview, Florida Solar Energy Center. Viewed at http://www.fsec.ucf.edu/PVT/Projects/pvbldgs/prog_info.htm\#overview.

${ }^{\dagger}$ U.S. Department of Energy, Database of State Incentives for Renewable Energy; http://www.dsireusa.org.
} 


\section{ILLINOIS}

Although only the $24^{\text {th }}$ largest U.S. state in terms of area, Illinois ranks fifth in the nation in terms of population and seventh in electricity consumption. Illinois is heavily dependent on nuclear power and coal for electricity; these resources account for $50 \%$ and $45.3 \%$ of the state's generation, respectively. Additional electricity is generated by natural gas $(3.5 \%)$, other resources $(0.7 \%)$, petroleum $(0.5 \%)$ and hydro $(0.1 \%) .{ }^{*}$ In 1999 , the average retail price of power in Illinois $(6.98$ cents $/ \mathrm{kWh})$ was the $18^{\text {th }}$ highest among states. The average residential rate in Illinois was 8.83 cents/kWh in 1999; the average commercial rate was 7.39 cents/kWh. ${ }^{\dagger}$

The installed renewable energy capacity of Illinois' electric plants was only $100 \mathrm{MW}$ in 2000, according to the Renewable Electric Plant Information System (REPiS) database. (Note that this figure includes biomass, hydro, photovoltaics, and wind.) Illinois has excellent biomass potential. The U.S. Department of Energy estimates that the state could produce an annual sum of 48.5 million MWh of electricity in this arena - enough to fulfill the demands of $130 \%$ of the residential sector. The full realization of Illinois' strong wind power potential would yield approximately 61 million MWh, a sum equal to $49 \%$ of the entire state's electricity consumption. The state has moderate solar potential, and hydro resources are relatively poor. ${ }^{\S}$ Landfill gas currently dominates renewable energy production at more than 200MW of installed capacity. ${ }^{* *}$ Ethanol production receives increasing attention; Illinois now dedicates $17 \%$ of its corn crop toward the production of this resource. ${ }^{\dagger t}$

Illinois has a handful of incentives and policies to promote renewable energy use, including grants, loans, and tax exemptions. For a summary of selected renewable energy incentives and policies, see Table 18 .

\section{Table 18: Selected Illinois Renewable Energy Policies}

\begin{tabular}{||l|l||}
\hline Property Tax Assessment & $\begin{array}{l}\text { Solar, wind, and geothermal systems are valued no greater than conventional } \\
\text { heating systems for property tax purposes. }\end{array}$ \\
\hline Grant and Loan Programs & $\begin{array}{l}\text { Illinois offers grants and loans for renewables through funding from the state } \\
\text { public-benefits funds. }\end{array}$ \\
\hline Public-Benefits Funds & $\begin{array}{l}\text { Two programs have been developed: the Renewable Energy Resources Trust } \\
\text { Fund and the Clean Energy Community Trust Fund. }\end{array}$ \\
\hline Net Metering & $\begin{array}{l}\text { Commonwealth Edison customers can net-meter solar and wind systems up to } \\
40 \mathrm{~kW} .\end{array}$ \\
\hline Disclosure & Utilities must inform customers of generation of fuel mix and emissions. \\
\hline
\end{tabular}

\footnotetext{
* State Electricity Profiles, U.S. Department of Energy, 1999.

${ }^{\dagger}$ Ibid.

${ }^{*}$ U.S. Department of Energy, Renewable Electric Plant Information System (REPiS) database, 2000. Note that this figure includes only biomass, hydro, photovoltaics, and wind.

$\S$ State Energy Alternatives, Energy Efficiency and Renewable Energy Network. Viewed June 13, 2002.

** Bolinger, M., and Wiser, R. "Clean Energy Funds: An Overview of State Support for Renewable Energy." Lawrence Berkeley National Laboratory, April 2001 (62).

${ }^{\dagger}$ Illinois Department of Commerce \& Community Affairs. Viewed at http://www.commerce.state.il.us/resource_efficiency/Energy/AlternativeEnergy.htm.

${ }^{\sharp}$ U.S. Department of Energy, Database of State Incentives for Renewable Energy; http://www.dsireusa.org.
} 


\section{IOWA}

Iowa, the nation's $23^{\text {rd }}$ largest state, ranks $30^{\text {th }}$ in terms of population and $31^{\text {st }}$ in terms of electricity consumption. For the generation of electric power, Iowa overwhelmingly depends on coal, which accounts for a full $85.4 \%$ of total generation. Nuclear provides an additional $9.4 \%$ of Iowa's power, with hydro $(2.4 \%)$, gas $(1.3 \%)$, other resources $(1.0 \%)$, and petroleum $(0.4 \%)$ accounting for the remainder. ${ }^{*}$ In 1999 , Iowa weighed in at $29^{\text {th }}$ in terms of highest retail price of electricity, with an average rate of 5.93 cents $/ \mathrm{kWh}$. The state's average residential rate for 1999 was 8.35 cents $/ \mathrm{kWh}$, while its average commercial rate was 6.45 cents/kWh. ${ }^{\dagger}$

According to the Renewable Electric Plant Information System (REPiS) database, the installed renewable energy capacity of Iowa's electric plants was $411 \mathrm{MW}$ in $2000 .{ }^{\ddagger}$ Iowa has substantial biomass potential. The U.S. Department of Energy estimates that 47.7 million MWh of electricity could be generated using renewable biomass fuels in the state. Wind resources are excellent and, if fully tapped, could produce 551 million MWh of power. Iowa's hydro potential is moderate, with an estimated 2.28 million MWh of potential generation. The state's solar potential is modest. ${ }^{\S}$ Of note is the fact that Iowa produces $22 \%$ of the nation's ethanol, with at least 10 new ethanol production plants planned during the next five years.

Iowa offers a host of renewable energy policies and incentives, summarized in Table 19 below. Most notable for on-site generation are the tax exemptions, the loan program, and net metering.

Table 19: Selected Iowa Renewable Energy Policies ${ }^{* *}$

\begin{tabular}{||l|l||}
\hline $\begin{array}{l}\text { Special Assessment of } \\
\text { Wind Energy Devices }\end{array}$ & $\begin{array}{l}\text { Cities and counties are authorized to assess wind energy conversion equipment at a } \\
\text { special valuation for property-tax purposes. }\end{array}$ \\
\hline $\begin{array}{l}\text { Property-Tax } \\
\text { Exemptions }\end{array}$ & $\begin{array}{l}\text { The added value of installing a solar energy system on a building shall not be } \\
\text { included in the property-tax assessment for the first five full assessment years. In a } \\
\text { separate provision, property used to convert methane gas to energy is exempt from } \\
\text { state property tax. }\end{array}$ \\
\hline Sales-Tax Exemption & $\begin{array}{l}\text { The total cost of wind energy equipment and all materials used to manufacture, } \\
\text { install, or construct wind energy systems is exempt from the state sales tax. }\end{array}$ \\
\hline Grant Program & $\begin{array}{l}\text { Research grants are awarded in three categories: renewable energy, energy } \\
\text { efficiency, and information transfer. Amount varies. Available only to Iowa-based } \\
\text { nonprofit groups. }\end{array}$ \\
\hline Net Metering & Net metering is allowed by investor-owned utilities for renewable energy systems. \\
\hline Renewables Set-Aside & $\begin{array}{l}\text { Investor-owned utilities are required to purchase a combined total of } 105 \text { MW of } \\
\text { their generation from renewable and small hydropower sources. }\end{array}$ \\
\hline Loan Program & $\begin{array}{l}\text { Zero-interest loans are available for up to half of the project cost up to a maximum } \\
\text { of \$250,000. Technologies include solar, methane, biomass, and wind. }\end{array}$ \\
\hline
\end{tabular}

\footnotetext{
* State Electricity Profiles, U.S., Department of Energy, 1999.

$\dagger$ Ibid.

*U.S. Department of Energy, Renewable Electric Plant Information System (REPiS) database, 2000. Note that this figure includes only biomass, hydro, photovoltaics, and wind.

$\S$ State Energy Alternatives, Energy Efficiency and Renewable Energy Network. Viewed June 13, 2002.

${ }^{* *}$ U.S. Department of Energy, Database of State Incentives for Renewable Energy.
} 


\section{NEW YORK}

New York is the third most populous state in the nation and ranks eighth in residential electricity sales. The state's electric power generation base is diverse, with gas comprising about a third of total generation. Nuclear supplies about $25 \%$ of the state's electricity needs, with hydro (16\%), coal (15\%), oil $(9 \%)$, and other resources $(<1 \%)$ making up the remainder. ${ }^{*}$ The average price of electricity in New York has historically been one of the highest in the country. Average residential electricity costs increased from $13.2 \phi / \mathrm{kWh}$ in 1999 to $14.1 \notin / \mathrm{kWh}$ in 2000 . Average commercial electricity costs increased from $11.0 \notin / \mathrm{kWh}$ to $12.5 \phi / \mathrm{kWh}$ during the same period.

The installed renewable energy capacity of New York's electric plants was a respectable 6,057 MW in 2000, according to the Renewable Electric Plant Information System (REPiS) database. ${ }^{\ddagger}$ The state has excellent hydro potential, which is already widely used, good wind potential (Class 4 and higher), as well as significant biomass and landfill gas potential. The state has a relatively poor solar resource. ${ }^{\S}$ Conventional hydroelectricity capacity represents almost $92 \%$ of the renewable energy capacity. Wind represents $1 \%$ of all renewable energy sources, followed by landfill gas $(0.9 \%)$, and wood and wood waste $(0.8 \%)$.

New York has a variety of incentives and policies that promote the use of renewable energy, including loans, grants, rebates, and tax credits, outlined below in Table 20.

\section{Table 20: Selected New York State Renewable Energy Policies ${ }^{\dagger \dagger}$}

\begin{tabular}{||l|l||}
\hline Personal Tax Credit & $\begin{array}{l}\text { A 25\% tax credit (\$3,750 max.) is available for net-metered PV systems up to 10 } \\
\text { kW. }\end{array}$ \\
\hline Green-Building Credit & Tax credits are available for PV and fuel cells integrated into buildings. \\
\hline Property-Tax Exemption & $\begin{array}{l}\text { This exemption is equal to the increase in assessed value attributable to a solar or } \\
\text { wind energy system. }\end{array}$ \\
\hline Loan & $\begin{array}{l}\text { The Energy \$mart Loan Fund for renewables and energy efficiency offers interest- } \\
\text { rate reductions on loans from participating lenders. }\end{array}$ \\
\hline PV Rebate & Residential PV systems qualify for a rebate of \$3/Watt. \\
\hline R\&D Grants & $\begin{array}{l}\text { Grants from } \$ 10,000 \text { to \$200,000 are available to fund up to 50\% of a project's } \\
\text { costs. }\end{array}$ \\
\hline $\begin{array}{l}\text { New-Construction } \\
\text { Program }\end{array}$ & $\begin{array}{l}\text { Provides incentives of up to \$300,000/project for design and installation of } \\
\text { building-integrated PV and advanced solar and daylighting technologies. }\end{array}$ \\
\hline Public-Benefits Fund & $\begin{array}{l}\text { Funded by a system benefits charge, this fund supports renewable energy, low- } \\
\text { income and energy efficiency programs, including the Energy \$mart Programs. }\end{array}$ \\
\hline Net Metering & $\begin{array}{l}\text { Statewide, net metering is allowed for residential PV systems up to } 10 \mathrm{~kW} \text {, and } \\
\text { standardized interconnection rules are in place. }\end{array}$ \\
\hline
\end{tabular}

\footnotetext{
* State Electricity Profiles, U.S. Department of Energy, 1999.

${ }^{\dagger}$ Draft New York State Energy Plan and Draft Environmental Impact Statement, New York State Energy

Planning Board, December 2001.

W.S. Department of Energy, Renewable Electric Plant Information System (REPiS) database, 2000. Note that this figure includes only biomass, hydro, photovoltaics, and wind.

${ }^{\S}$ State Energy Alternatives, Energy Efficiency and Renewable Energy Network. Viewed June 13, 2002.

** Draft New York State Energy Plan and Draft Environmental Impact Statement, December 2001.

${ }^{\dagger}$ U.S. Department of Energy, Database of State Incentives for Renewable Energy.
} 


\section{NORTH CAROLINA}

Although North Carolina is only the $29^{\text {th }}$ largest state area-wise, it ranks $11^{\text {th }}$ in population and eighth in electricity consumption. The state relies heavily on coal (61.6\%) and nuclear power $(31.9 \%)$ for electricity generation, with hydro $(3.3 \%)$, other resources $(1.4 \%)$, natural gas $(1.0 \%)$, and petroleum $(0.8 \%)$ playing relatively minor roles.

At 6.44 cents $/ \mathrm{kWh}$, the average retail price of electricity in North Carolina was the $21^{\text {st }}$ highest in the United States in 1999. During this time, the average residential rate was 7.99 cents/kWh, while the average commercial rate was 6.33 cents $/ \mathrm{kWh} .^{\dagger}$

The installed renewable energy capacity of the state's electric plants was 2,063 MW in 2000, according to the Renewable Electric Plant Information System (REPiS) database. North Carolina has very good biomass potential, with an estimated 14.3 million MWh of generation possible annually, according to the U.S. Department of Energy. There are excellent wind resources in the western portion of the state; up to 8 million MWh of electricity could be generated annually with utility-scale wind turbines. Hydro resources are moderate, providing the potential for an estimated 8 million MWh of electricity annually. North Carolina has moderate solar potential. ${ }^{\S}$

North Carolina has a limited number of incentives and policies in place to encourage the use of renewable energy. Included are a generous tax credit and a property-tax exemption. See Table 21 below for a summary of North Carolina's incentives and policies.

\section{Table 21: Selected North Carolina Renewable Energy Policies**}

\begin{tabular}{||l|l||}
\hline $\begin{array}{l}\text { Corporate and Personal } \\
\text { Tax Credit }\end{array}$ & $\begin{array}{l}\text { A } 35 \% \text { tax credit is available for all renewable energy systems, with maximum } \\
\text { limits varying by technology and sector. }\end{array}$ \\
\hline Loan Program & $\begin{array}{l}\text { 1\% interest loans are available to finance commercial, government, and nonprofit } \\
\text { renewable energy projects, including solar, methane, biomass, and wind. The } \\
\text { maximum loan is } \$ 500,000 .\end{array}$ \\
\hline $\begin{array}{l}\text { Property-Tax } \\
\text { Exemption }\end{array}$ & $\begin{array}{l}\text { This exemption allows for active solar heating and cooling systems to be assessed at } \\
\text { not more than the value of a conventional system for the purposes of property } \\
\text { taxation. }\end{array}$ \\
\hline Industry Recruitment & $\begin{array}{l}\text { A corporate income-tax credit is available to manufacturers of PV systems. The } \\
\text { credit is } 25 \% \text { of the installation and equipment costs of construction. }\end{array}$ \\
\hline
\end{tabular}

\footnotetext{
* State Electricity Profiles, U.S. Department of Energy, 1999.

$\dagger$ Ibid.

* U.S. Department of Energy, Renewable Electric Plant Information System (REPiS) database, 2000. Note that this figure includes only biomass, hydro, photovoltaics, and wind.

${ }_{* *}^{\S}$ State Energy Alternatives, Energy Efficiency and Renewable Energy Network. Viewed June 13, 2002.

${ }^{* *}$ U.S. Department of Energy, Database of State Incentives for Renewable Energy.
} 


\section{OREGON}

Oregon is the nation's $10^{\text {th }}$ largest state and ranks $28^{\text {th }}$ in population. In terms of electricity consumption, the state ranks $26^{\text {th }}$. Oregon is unique, in that a whopping four-fifths of its electricity is generated by hydro resources. The remainder of the state's electricity is generated by gas $(12 \%)$, coal $(6.6 \%)$ and other resources $(1.0 \%)$. ${ }^{*}$ At 4.87 cents/kWh, Oregon had one of the cheapest average retail rates in the country in 1999; this average ranked $46^{\text {th }}$ among U.S. states. During this period, the average residential rate and commercial rate were 5.75 cents/kWh and 4.94 cents/kWh, respectively. ${ }^{\dagger}$

The installed renewable energy capacity of Oregon's electric plants was an admirable 8,424 MW in 2000, according to the Renewable Electric Plant Information System (REPiS) database. In addition to its abundant hydro resources, Oregon has strong biomass potential, with the capability of producing an estimated 14.3 million MWh of electricity annually. Moreover, the state's excellent wind resource potential could contribute an annual sum of 50 million MWh per year. However, landfill-gas development potential is limited, and solar potential is relatively poor. ${ }^{\S}$ Oregon remains at the forefront on environmental issues, and this is certainly true with respect to renewable energy production. Despite its relatively poor solar potential, the state ranks fifth nationally in the number of solar systems purchased.

Oregon boasts a variety of incentives and policies to promote the use of renewable energy, including tax credits and exemptions, loans, and rebates. See Table 22 for a summary of key incentives and policies.

Table 22: Selected Oregon Renewable Energy Policies ${ }^{* *}$

\begin{tabular}{|c|c|}
\hline Business Energy Tax Credit & $\begin{array}{l}\text { A } 35 \% \text { tax credit up to } \$ 10 \text { million is available for renewable energy and } \\
\text { recycling projects. }\end{array}$ \\
\hline $\begin{array}{l}\text { Residential Energy Tax } \\
\text { Credit }\end{array}$ & $\begin{array}{l}\text { Tax credits up to } \$ 1,500 \text { are allowed for residential renewable systems, as well } \\
\text { as energy-efficient appliances and duct work. }\end{array}$ \\
\hline $\begin{array}{l}\text { Small-Scale Energy Loan } \\
\text { Program }\end{array}$ & $\begin{array}{l}\text { This program makes loans of } \$ 20 \mathrm{k} \text { up to } \$ 20 \text { million for residential, } \\
\text { commercial, and public-sector energy projects. }\end{array}$ \\
\hline Property-Tax Exemption & $\begin{array}{l}\text { Renewable energy systems do not add to assessed property value for tax } \\
\text { purposes. }\end{array}$ \\
\hline Remote PV Rebate & $\begin{array}{l}\text { For PV-powered remote water-pumping systems, the Oregon Energy Office } \\
\text { offers technical assistance and a } \$ 100 \text { rebate. }\end{array}$ \\
\hline Rebate Program & A rebate of $\$ 2,000$ is available for residential off-grid $\mathrm{PV}$. \\
\hline Public-Benefits Fund & $\begin{array}{l}\text { Funded by a public-benefits charge, this fund supports renewable energy, } \\
\text { energy conservation and market transformation, low-income weatherization } \\
\text { programs, and school energy programs. }\end{array}$ \\
\hline Net Metering & $\begin{array}{l}\text { Solar, wind, biomass, and fuel cell systems up to } 25 \mathrm{~kW} \text { are eligible. Simplified } \\
\text { interconnection rules have been established by most of the state's utilities. }\end{array}$ \\
\hline
\end{tabular}

\footnotetext{
* State Electricity Profiles, Energy Information Administration, 1999.

${ }^{\dagger}$ Ibid.

*U.S. Department of Energy, Renewable Electric Plant Information System (REPiS) database, 2000. Note that this figure includes only biomass, hydro, photovoltaics, and wind.

${ }_{* *}^{\S}$ State Energy Alternatives, Energy Efficiency and Renewable Energy Network. Viewed June 13, 2002.

${ }^{* *}$ U.S. Department of Energy, Database of State Incentives for Renewable Energy.
} 


\section{ENDNOTES}

\footnotetext{
${ }^{1}$ See, for example, Starrs, T. J. and V. Schwent. "Government Buy-Downs for the Residential Market" in Expanding Markets for Photovoltaics: What To Do Next. Renewable Energy Policy Project Special Report, December 1998; American Wind Energy Association. "Structuring a "Buy-Down" Program for Small Renewable Energy Systems: Some Recommendations." Wind Energy Fact Sheet. Viewed at http://www.awea.org/pubs/factsheets/buydwn_fs.PDF on September 26, 2001; and Koontz, R. and Neuendorffer, J., et al. State Solar Initiatives: A Review. Prepared for the U.S. Department of Energy. Volume 1. September 1981. SERI/TR-722-882; and American Solar Energy Association, "Policy Statement on Tax Credits and Subsidies for Sustainable Energy Technologies." July 2001; Rader, N. and R. Wiser. Strategies for Supporting Wind Energy: A Review and Analysis of State Policy Options. National Conference of State Legislatures, 1999.

${ }^{2}$ Rader, N. and Wiser, R. Strategies for Supporting Wind Energy: A Review and Analysis of State Policy Options. National Wind Coordinating Committee. 1999.

${ }^{3}$ Wiser, R.H., Evaluating the Impacts of State Renewables Policies on Federal Tax Credit Programs. California Energy Commission Renewables Program Committee, December 1996.

${ }^{4}$ Rogers, H., Larsen, C., and Shirley, L. National Summary Report on State Financial Incentives for Renewable Energy. North Carolina Solar Center and the Interstate Renewable Energy Council. July 1997.

${ }^{5}$ Starrs, T. J. and V. Schwent. "Government Buy-Downs for the Residential Market" in Expanding Markets for Photovoltaics: What To Do Next. Renewable Energy Policy Project Special Report, December 1998.

${ }^{6}$ Ibid.

${ }^{7}$ Rader, N. and R. Wiser, 1999.

${ }^{8}$ Starrs, T. J. and V. Schwent. 1998.

${ }^{9}$ Ibid.

${ }^{10}$ Wiser, R.H., 1996.

${ }^{11}$ U.S. Department of Energy, Database of State Incentives for Renewable Energy; http://www.dsireusa.org.

${ }^{12}$ Ibid.

${ }^{13}$ Bolinger, M. and R. Wiser. Customer-Sited PV: A Survey of Clean Energy Fund Support. Clean Energy Group/Clean Energy Funds Network. May 2002.

${ }^{14}$ Rader, N. and R. Wiser, 1999.

${ }^{15}$ Ibid.

${ }^{16}$ Rogers, H., Larsen, C., and Shirley, L., 1997.

${ }^{17}$ Wiser, R.H., 1996.

${ }^{18}$ Iowa Department of Natural Resources, "A Midwest Study of Attitudes and Opinions Towards Photovoltaic Technology." 2001.

${ }^{19}$ Guidelines for Determining the Tax Credit for Investing in Renewable Energy Property, North Carolina Department of Revenue, December 4, 2000.

${ }^{20}$ Oregon Office of Energy Web site. Viewed at www.energy.state.or.us/bus/tax/taxcdt.htm.

${ }^{21}$ Oregon Office of Energy, Residential Energy Tax Credit Brochure, viewed at http://www.energy.state.or.us/res/tax/retcbro.pdf; and 2002 Update, viewed at http://www.energy.state.or.us/res/tax/2002.pdf.

${ }^{22}$ Conservation Program Savings report http://www.energy.state.or.us/pub.htm.

${ }^{23}$ Jennifer Szaro, FSEC, personal communication; results based on 100 responses still being compiled.

${ }^{24} \mathrm{See} \mathrm{http} / / / \mathrm{www}$. energy.iastate.edu/about/grantloan/AERLP/index.htm.
} 


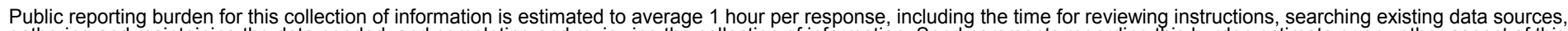

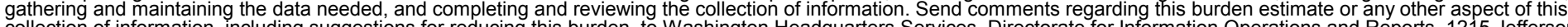
this burden, to Washington Headquarters Services, Directorate for lnormation Operations and Reports, 1215 Jefferson Davis Highway, Suite 1204, Arlington, VA 22202-4302, and to the Office of Management and Budget, Paperwork Reduction Project (0704-0188), Washington, DC 20503.
1. AGENCY USE ONLY (Leave blank)
2. REPORT DATE
September 2002
3. REPORT TYPE AND DATES COVERED
Subcontract Report - Analysis

\section{TITLE AND SUBTITLE \\ Case Studies on the Effectiveness of State Financial Incentives for Renewable Energy}

6. $\operatorname{AUTHOR}(\mathrm{S})$

S. Gouchoe, V. Everette, and R. Haynes

5. FUNDING NUMBERS

TA: AS61.1000

7. PERFORMING ORGANIZATION NAME(S) AND ADDRESS(ES)

North Carolina Solar Center

North Carolina State University

P.O. Box 7401

Raleigh, NC 27695-7401

9. SPONSORING/MONITORING AGENCY NAME(S) AND ADDRESS(ES)

National Renewable Energy Laboratory

1617 Cole Blvd.

Golden, CO 80401-3393

8. PERFORMING ORGANIZATION REPORT NUMBER

C: ADC-1-31425-01

10. SPONSORING/MONITORING AGENCY REPORT NUMBER

NREL/SR-620-32819

11. SUPPLEMENTARY NOTES

NREL Technical Monitor: Larry Goldstein

12a. DISTRIBUTION/AVAILABILITY STATEMENT

National Technical Information Service

U.S. Department of Commerce

5285 Port Royal Road

Springfield, VA 22161

ABSTRACT (Maximum 200 word). The North Carolina Solar Center at NC State University, in collaboration with the National Renewable Energy Laboratory, examined 10 state financial-incentive programs in six states using a case-study approach in order to clarify the key factors-both internal and external to the program-that influence their effectiveness at stimulating deployment of renewable energy technologies. While existing information resources such as the National Database of State Incentives for Renewable Energy (DSIRE, www.dsireusa.org) have documented what incentive programs are available, the effectiveness of such programs is not well understood. Understanding the impact of current financial incentives on the deployment of renewables and the factors that influence their effectiveness is critical to a variety of stakeholders, particularly in states considering new incentives or interested in improving or discarding existing ones.

14. SUBJECT TERMS

state financial incentives; buy-downs; loan programs; tax credits; Oregon; New York;

Florida; Illinois; lowa; North Carolina Solar Center; North Carolina State University; solar; wind; photovoltaics; biomass; distribution network

17. SECURITY CLASSIFICATION OF REPORT

Unclassified
18. SECURITY CLASSIFICATION OF THIS PAGE Unclassified
19. SECURITY CLASSIFICATION OF ABSTRACT Unclassified
15. NUMBER OF PAGES

16. PRICE CODE

20. LIMITATION OF ABSTRACT

UL 